\title{
Social Change, Dress and Identity
}

\author{
Observations on the Disintegration of Peasant Culture \\ as Exemplified by Rural Women's Clothing in Hungary \\ from the First World War to the End of the Kádár Era Socialism
}

Received: May 2, 2020 • Accepted May 20, 2020

\author{
Ágnes Fülemile \\ Institute of Ethnology, Research Centre for the Humanities, Budapest
}

\begin{abstract}
The article, based on extensive ethnographic fieldwork, studies the process of the disintegration of the traditional system of peasant costume in the $20^{\text {th }}$ century in Hungary in the backdrop of its socio-historic context. There is a focused attention on the period during socialism from the late 1940s to the end of the Kádár era, also called Gulyás communism. In the examined period, the wearing and abandonment of folk costume in local peasant communities was primarily characteristic of women and an important part of women's competence and decision-making. There was an age group that experienced the dichotomy of peasant heritage and the realities of socialist modernisation as a challenge in their own lifetime - which they considered a great watershed. The author interviewed both the last stewards of tradition who continued wearing costume for the rest of their lives and those who pioneered and implemented changes and abandoned peasant costume in favor of urban dress. The liminal period of change, the character and logic of the processes and motivations behind decision-making were still accessible in memory, and current dressing practices and the folklorism phenomena of the "afterlife" of costume could still be studied in real life. The study shows that costume was the focus point of women's aspirations, attention, and life organization, and how the life paths of strong female personalities were articulated around clothing. It also reveals that there was a high level of self-awareness and strong emotional attachment in individual relationships to clothing in the rural context, similar to - or perhaps even exceeding - the fashion-conscious, individualized urban context. Examining the role of fashion, modernization, and individual decisions and attitudes in traditional clothing systems is an approach that bridges the mostly distinct study of folk costume and the problematics of dress and fashion history research.

Keywords: abandonment of folk costume, system of traditional clothing, urban dress, peasant culture, peasant identity, liminality, fashion, the role of personality, dress and identity, communist era, collectivization, Kádár era, socialist modernization, socialist consumption, afterlife of tradition, practices of remembrance
\end{abstract}




\section{THE CONTEXT OF THE SUBJECT MATTER AND RESEARCH}

For about five years in the mid-1980s, I studied the recent processes of the disintegration and functional restructuring of peasant culture through the example of clothing. The work was based on specific data collection and fieldwork. I studied the changes in peasant women's clothing in villages where the abandonment of folk costumes, the transition from peasant dress to a more urban dress, i.e., "un-dressing," took place between the two world wars, or even later, in the decades after World War II.

Many of the villages studied used to have a typical, colorful women's folk costume with multi-layered skirts, considered "peasant" by public opinion, and traditional dress was an important visual element here, a distinctive marker of local culture.

At the time of my research, a portion of the older female generation in some of the villages was still wearing traditional dress (not just on holidays but also on weekdays), whereby the processes of change in dress style and motivations behind their decisions were still accessible by memory. There was an age group that faced a challenge in their own lifetime - which they experienced as a great watershed - of whether to keep the traditional dress or innovate and abandon the frameworks of tradition. Therefore I sought out local communities where I could reach both groups, those who were the last heralds of the tradition and continued wearing traditional dress for the rest of their lives, as well as those who pioneered and implemented changes at the time.

I mainly examined the process of the abandonment of folk costume, the new clothing choices of the first generation to have abandoned traditional dress, the recent use of folk costume by those who retained it, the new functions and meanings of the retained costume, and essentially the relationship of each generation to local peasant dress. ${ }^{2}$ I also wanted to explore the systematic rearrangements (in material culture, values, gender roles, decorum, etc.), what part in a larger strategy the changes in clothing played, and what new system the retained or changed clothing formed. ${ }^{3}$

I focused primarily on the process of style changes in women's clothing, as traditional men's clothing had been replaced in most places by a not entirely fashion-forward but modernized, more urban clothing as early as the first decades of the 20th century. Their greater mobility, their experiences in the military, in the city, and their work in industry (mining, construction etc.) played a role in the men's earlier change of clothing style.

${ }^{1}$ A common term used by the locals, which is now also an ethnographic term. Locals also use expressions like "casting off the costume," "distorting the costume," "molting," or "changing dress."

2 Anglo-Saxon dress historians often use the term 'ethnic dress' when speaking of the traditional dress of rural peasant populations with distinctive local features, popularly called folk costume. I consider the term 'ethnic dress' imprecise and problematic, especially in a strongly multiethnic area such as East-Central Europe. In this article, I variably use the terms traditional, peasant, or folk costume, dress, or clothing.

3 I did not consider it my task at that time to conduct a comprehensive study of the dress culture of the younger generations who had never worn folk costume. Having had included in this same study an analysis of the further development and afterlife of folk dress - taken out of its original context and used in a fancy dress-like way, as a curiosity or a symbol - would have taken me in a very different direction. At the time, I also did not address the integration of folk costume into mass culture and national culture. In my later writings, I addressed some of these issues, see FüLEMILE 2010, 2011. 
The time lapse in the abandonment of folk costume by the two sexes could sometimes be as much as $40-50$ years.

In the examined period, the wearing and abandonment of folk costume in local peasant societies was therefore primarily characteristic of women, an important part of women's competence and decision-making. Costume was in the focus of women's aspirations, attention, and life organization. The life paths of strong female personalities were articulated around clothing, as was the preservation, production, and transmission of the knowledge regarding clothing. The narrative of the abandonment of traditional dress fit into the events of individual life paths and understanding the emotional value of costume and relationship to clothing revealed a number of women's lots. Therefore, even if I had approached the female sphere not in isolation but in a complex interaction intertwined with male society, the topic became a kind of gender research, whether I intended it or not.

Researching the changes in peasant clothing and reconstructing its system was not my primary goal par excellence - I was seeking a research tool to understand a broader context, the social history of the era. Clothing is a sensitive means of expressing identity. As part of the sphere of representation, in a visually decodable way, it acts as a kind of fresh, sensitive sensor of socio-economic processes, and immediately shows the changes in the identity and prestige of the wearer, the real and desired motivations and aspirations behind self-expression. ${ }^{4}$

As a mentor, Edit Fél directed my research for five years until her death in June $1988 .{ }^{5}$

This paper is a revised, updated, and significantly expanded version of an earlier study of mine, the material for which I collected during the last decade of Hungarian socialism,

${ }_{4}$ Barthes underlines the relevance of socio-historical interpretation in the history of dress and the necessary dialectics between synchronic (structure of system) and diachronic (process) study: "What should really interest the researcher, historian or sociologist, is... the tendency of every bodily covering to insert itself into an organized, formal and normative system that is recognized by society." (BARTHES 2013:6). Clothes live in tight symbiosis with their historical context..." (BARTHES 2013:11). "We cannot stress too much, by a way of conclusion, that the history of dress has a general epistemological value. It actually suggests to the researcher the essential problems in all cultural analysis, culture being both system and progress, institution and individual act, a reserve of expression and a signifying other." (BARTHES 2013:14).

5 Edit Fél (1910-1988) is a particularly dominant figure in Hungarian ethnography. She pioneered research in social and economic ethnography, folk art, costume, and textile studies. She developed the concept of the ambitious Átány study in the early 1950s, when the communist political turn made clear the imminent rapid transformation of the peasant world. Her books on the economy and society of Átány, a Calvinist Hungarian village - written with her co-author and disciple Tamás Hofer - and published in the USA, Germany, and Denmark (HoFer - FÉL 1969b, 1972, 1974), received great international publicity. The findings could not be published in socialist Hungary, and the books could only be published in Hungarian translation after the regime change. Another one of her complex analyses of the Catholic worldview of a peasant woman in Mezőkövesd was similarly published abroad, in France (lauded by Pierre Chaunu) (FéL 1983). Throughout her career, Edit Fél maintained a fresh methodological approach and intensively kept up with the international research trends of her time and brought the ideas of social anthropology to Hungary. Despite the fact that she was politically considered persona non grata by the communists, and which cost her university chair, she continued to maintain ties with western scholars in English, French, and German, including Claude Lévi-Strauss, Marcel Maget, Arthur Haberlandt, Viktor Geramb, Richard Weiss, René König, 
the Kádár era, ${ }^{6}$ and whose text was finalized in 1989 but published only two years later, after the political change, in the Edit Fél memorial issue of Ethnographia edited by Tamás Hofer (FüLEMILE 1991b). I thought it worthwhile to publish the research findings in English because the citation of the article in Hungary and its republishing (FÜLEMILE 2000 ) at the request of social researchers shows that historians and sociologists dealing with the social history and way of life of the socialist decades consider the research findings relevant. ${ }^{7}$ The English-language publication is also justified by the fact that the topic elicited a positive response in the American research community as well. ${ }^{8}$

Arie Nicolaas Jan den Hollander, Sol Tax, and Stella Mary Newton. It is no coincidence that Edit Fél's approach brought a breakthrough not only in the field of social research but also in fieldwork, and the more sophisticated museological concept that contributed to the enrichment of the museum collection was the fruit of her more holistic approach to fieldwork. As the head of the Textile Collection of the Museum of Ethnography, it was she who developed the collection that became the largest textile collection in Europe. A good half of the nearly sixty thousand articles were collected from the field personally by Fél herself. The museum was the place where she could "hide" in the warehouse and work unbothered. When she was dismissed from the university in 1949 because of a communist turn in science policies, she could no longer formally teach, but she did work with some private students, and I was fortunate to be one of them. Many of the ideas in this study had been discussed with her. I think it is unnecessary to stress what a defining experience and source of inspiration my relationship with her had been.

6 The main communist leader János Kádár's (1912-1989) name marked a long period in the history of Hungary, from the crushed anti-Soviet revolution of 1956 until the political change in 1990. He was chosen by the Soviets as the leader of the Hungarian People's Republic as General Secretary of the Hungarian Socialist Workers' Party. He had personal responsibility in the reign of terror after 1956, which was only gradually eased by the first half of the 1960s. Liberalization under his tenure was an ongoing process, under his "Goulash Communism," there was a relatively high standard of living, relaxed travel restrictions, and more liberal cultural life than in other countries of the Eastern Bloc beyond the "Iron Curtain." As a result Hungary became known as "the happiest barrack."

7 There is a serious tradition of folk costume research in Hungarian ethnography. Its greatest figure was the above mentioned Edit Fél. Mostly local monographs have been published, (more recently, TöTSZEGI on the dress of the village of Méra in Kalotaszeg, Transylvania, represents a thrillingly complex approach) as well as monographs of certain subjects with museological background knowledge (e.g. on woollen garments, leather garments, undergarments, cifraszür/embroidered wool coat), and the catalog of the collections of the Museum of Ethnography). There are also several publications of historical archival sources of various types (inventories, testaments, accounts, price lists, many by Mária Flórián and Györgyi Csukás at the Institute of Ethnology of the Hungarian Academy of Sciences, not listed here in detail), but there are relatively few compendia. In the more recent literature, however, the lengthier, synthesizing chapter of the Handbook of Hungarian Ethnography (FLóRIÁN 1997) unfortunately left out the discussion of the phenomenon of costume abandonment or did not treat the topic thoroughly enough (FLóRIÁN 2001). Even the few cited studies touch on certain aspects of costume abandonment mainly as a part of studies of socioethnographic issues, values, and mentality. In essence, the present study was the first to pay focused attention to a summary overview of the phenomenon.

8 During my first Fulbright research fellowship, I gave a lecture on the subject in the Department of Anthropology at the University of California, Berkeley at the request of Professor Alan Dundes, followed by a public lecture at the Metropolitan Museum in New York in 1993 at the request of Richard Martin, director of the Costume Institute. Emphasizing the merits of the Hungarian folkloristic school of personality research, Professor Dundes highlighted the personality-based approach and examination of personal motives in my research. In fashion historian Richard Martin's assessment, examining the role of fashion, modernization, and individual decisions in traditional clothing systems is a new and surprisingly exciting approach in fashion history research, a kind of bridge in a mostly distinct approach to folk costume and fashion. 


\section{A BRIEF HISTORY OF THE DEVELOPMENT OF HUNGARIAN FOLK COSTUME UP UNTIL ABANDONMENT}

To understand the abandonment of folk costume as a liminal phase of the disintegration of traditional culture, it is worthwhile to outline the basic premise in order to see in the context of social history what characterized the main periods of the development of folk dress before the idea of abandonment emerged. This is a point of departure against which we can understand the transitional phase of the disintegration of tradition and the complexity of the post-traditional period that follows.

Throughout most of its pre-modern history, Hungary had a predominantly agrarian economy, its society consisting mostly of peasants and nobles, ${ }^{9}$ with a thin and less influential stratum of burghers. At the end of the $19^{\text {th }}$ century, the agrarian population living in villages and agrarian towns still made up around $90 \%$ of the country's inhabitants. The institutions of the feudal system had only been gradually eliminated during the $19^{\text {th }}$ century. After the so-called Compromise of 1867 between Austria and Hungary, the remaining feudal privileges were abolished and a rapid economic, legal, and social modernization commenced. However, the ambiguous survival of a semi-feudal system allowed for the long persistence of a pre-modern value system, feudal patron-client relationships, and the strong social role model of the gentry, all of which left their imprint on people's mentality, value- orientation, and cultural preferences (including clothing habits) up until World War II. The agrarian population, generally and popularly referred to as peasants,${ }^{10}$ still constituted more than $50 \%$ of the country's inhabitants before the two-step forced communist collectivization at the turn of the 1950s and a decade later at the turn of the 1960s. From a sociological point of view, the agrarian population was stratified in all discussed periods, but they shared a relatively monolithic value system of dominantly middle-peasant roots. This middle-peasant-oriented mentality still characterized the "post-peasantry" of the socialist period far beyond collectivization.

One of the possible scholarly approaches to studying folk costume is to view the dress change within the context of a stylistic analysis and periodization of the entire

9 Besides a thin stratum of high aristocrats, the nobility was comprised of a relatively large group of middle and petty nobles. In fact, along with Poland, Hungary had proportionately the largest nobility in all of Europe.

10 The term paraszt (peasant) is a widely accepted expression in Hungarian ethnographical, historical, sociographical, and sociological research. It denotes a large part of the historical population (dealing with agriculture, animal husbandry, and crafts) that lived in the rural countryside, in villages and agrarian towns (oppidum). A larger portion of them came from feudal serf peasants (iobbagiones), while a smaller portion had free legal status (kind of a yeoman) in some regions and municipalities. In all historic periods, the peasantry was stratified from landless poor farmhands and cotters to well-to-do farmers. The term was willingly and proudly used by the denominants themselves and had positive connotations. (Even the term jobbágy, meaning iobbagiones, had a positive meaning in some villages until the $1980 \mathrm{~s}$, referring to the well-to-do farmers by this term.) The flip-side of the coin is a pejorative meaning originating from an elite and middle-class use of it as a derogatory term. Since its birth in the mid-19 $9^{\text {th }}$ century, Hungarian ethnography as an academic discipline has soundly dedicated itself to the study of the culture and society of the peasantry. On the other hand, the general umbrella term nép, i.e., folk, and its derivatives are considered more old-fashioned and imprecise and have been debated from socio-historical standpoints. 
complex of expressive peasant art in the backdrop of economic and social processes. ${ }^{11}$ Scholars established the categories of "old style," "new style," and "newest" or "latest style" of folk art, which can be applied to costume as well.

The old-style culture of the feudal serf-peasants - who lived in a more bound and less mobile society before the emancipation of serfs - was a more homogenous, less variegated class culture. Art was more communal and there was more emphasis on ritual functions. The simple attire was single- or double-layered with no undergarments. ${ }^{12}$ Besides the predominantly home-produced materials (homespun hemp linen, wool, and leather) and pieces of clothing, some basic items of dress were made by professional craftsmen. ${ }^{13}$ Remarkable regional differences did not exist yet, only certain larger cultural zones can be pointed out.

The stylistic development of folk culture and costume was largely due to the economic and social processes and the consolidation of lifestyle (as a result of multiple factors) in the $18^{\text {th }}$ and $19^{\text {th }}$ centuries. The prestige consumption of the peasantry began to grow gradually in the late $18^{\text {th }}$ and early $19^{\text {th }}$ century. Like an opening pair of scissors, more and more representative objects were purchased or produced at home. Following the elite custom of salons in noble mansions and town houses, an extra room, the socalled clean or front room was added to the dwelling house, where representative objects (furniture, textiles, pottery, etc.) were displayed and used only for festive events. Ceremonies and rituals became more complex as events were accompanied by poetry, ceremonial gestures and sayings, "dramatic plays," music, dance, exchanges of objects with symbolic meanings, and a more elaborate dress code.

There was a deep social chasm between the classes, and although there were certain opportunities for social interactions, social mobility, and trickle-down effects, on the whole, the culture and costume of Hungary's rural population started to get modernized much later and remained more autonomously "peasant" than in Western Europe. ${ }^{14}$

The new style of folk art evolved during the Age of Reform (1830s-40s) and romantic national awakening. The newly politicized, more democratic concept of nationhood set off a debate on the inequalities of the system and brought about the emancipation of

11 Thus, peculiarities and changes in the clothing system can be interpreted as part of, and in relation to, the other genres of folk culture - i.e., representative decorative objects, architecture, dance, music, and oral folklore. On the stylistic periodization of folk art see: HOFER - Fél 1979; HOFER 1980a.

12 The cut of the garments followed straight lines and used the entire width of the linen provided by the loom. Leggings and sleeves were narrow so as not to waste material. For summer, a single layer of linen was worn, while for winter and representative occasions, an additional layer of leather and/or woolen (woven or felt) upper garment was added. Some of these medieval-style, straightcut, homespun garments were retained as specific work clothes for harvesting up until the mid$20^{\text {th }}$ century. Archaic solutions were often preserved in children's costumes and specific burial garments as well. In some peripheral regions of the Hungarian-speaking territory (in the Gyimes Valley in Eastern Transylvania and among the Hungarian-speaking Roman Catholic Csángó people of Moldova), this archaic costume composition was preserved until very recently. More on the oldstyle folk dress, see FüLEMILE 2010:169-170.

13 Decorated objects were mostly produced in a few important urban centers and circulated in larger circles through fairs and long-distance catering and peddling.

14 In Western Europe, where an earlier and more integrative embourgeoisement and a smoother transition from rural to urban had occurred in the early modern period, the dress of common people was not so strongly independent of general fashion influences as in the case of East Central Europe. 
serfs $(1848,1853)$ and thematized ideas of equality before the law. The new style was an expression of the new, proud, self-aware social identity of peasants freed from the feudal yoke. Peasantry and folk art, which until then had been a social and cultural "terra incognita', was discovered by the upper classes as a treasure trove of "national values" and became a source of inspiration in the process of "inventing" national cultures. ${ }^{15}$

This was a major flourishing period in folk art, characterized by intensified local production and art activity, balanced, harmonious compositions, and the use of clear, basic colors. Variability, diversity, and creativity in every branch of the decorative arts and folklore led to regionalization. ${ }^{16}$ Many local styles were elaborated. Almost every distinct community created something typical, especially in costume, which began to serve as a conscious marker of local identity. Nuances of local specifics in dress, which to outsiders often appeared as minuscule differences, were especially important to members of the community, who verbalized differences in an "us" vs. "them" comparison. Internally, this increased self-awareness, while externally it emphasized boundaries. Costume thus became an important means of boundary-marking between localities and regions.

New-style peasant art became more autonomous. Individual artists started to take on leading roles in the community. A more self-aware artist identity was expressed through texts and monograms (on personally embroidered garments as well). Not only talented craftsmen, musicians, dancers, and storytellers were winning acclamation but so were dexterous, creative seamstresses and embroiderers as well. (While guild masters were usually men, becoming a local specialist dressmaker was a chance for women to gain fame and extra income.) Every community had its so-called "famous girls" (another strong female role) who introduced fashion innovations, dressed the most creatively, and thus shaped the taste of the female community as (role-)"models."

The high period of peasant costume in Hungary was the second half of the $19^{\text {th }}$ and first half of the $20^{\text {th }}$ century. By that period, many rural communities had developed a rich, expressive, variable clothing system with an elaborate array of sartorial symbols expressing rank, social status, family status, the age (and even the mood) of the wearer, as well as the occasions for wearing a certain outfit.

The increase in prestige representation reached such a level that decorated objects with representative, ritual, and symbolic functions doubled and tripled the number of everyday functional objects in an average household. At the beginning of the $19^{\text {th }}$ century, a woman might have had only a few pieces of garments and only one outfit for feast days. (More expensive, factory-produced materials were used only for a few

15 See, HoFer 1980b, 1984, 1991.

16 On the other hand, regional differences often originated from the fact that they preserved various stages of historical development. Regions and communities, even families or individuals, were characterized by their different attitudes toward and dynamics of accepting innovations and/or retaining conservative solutions. Roland Barthes, citing Fernand Braudel about the relativity of historical periodization, writes that histories of parallel phenomena "do not necessarily have the same tempo" and rhythm and pace of development (BARTHES 2013:6, 16). Original citation by Braudel: "Though we must of course be clear that social time does not flow at one even rate, but goes at a thousand different paces, swift or slow, which bear almost no relation to the day-to-day rhythm of a chronicle or of traditional history." See BRAUDEL, Fernand: Ecrits sur l'histoire, Paris: Flammarion 1969. 15-38. p. 24 (Translated by Sarah Matthews in Braudel, Fernand: On history, Chicago University Press, 1980.) 
small, material-sparing pieces of vests, aprons, or headscarves.) By the late $19^{\text {th }}$ and early $20^{\text {th }}$ centuries, a marriageable girl might possess a much larger ensemble of garments than it was imaginable in earlier times. That is why insistence on the permanence of the prevailing style and dress code increased within a generation. With the rejection of rapid changes, lagging behind fashion was counterbalanced with the elaboration of lavish local solutions with a high rate of adaptivity, resulting in strongly independent, very "peasant-flavored," "peasant-oriented" clothing styles. This created an increasingly obvious difference between a local peasant dress and a fashion-conscious city dress. The increased number of articles allowed for more elaborate meanings and symbolism and a greater variability of 'habillement', which also provided more opportunity to express individual taste and talent within the system. ${ }^{17}$ (Figure 1)

While regional costumes in Transylvania preserved more archaic features, ${ }^{18}$ the majority of regional costumes in central Hungary belonged to the so-called multi-skirted type of dress, or peasant crinoline. The style was a peasant interpretation of contemporary fashion and reflected the fashionable line of voluminous skirt shapes of the $1830 \mathrm{~s}-60 \mathrm{~s} .{ }^{19}$ Shirts had shorter puffed sleeves with laced fringes, also imitating the sleeve fashion of the 1830s-60s. Cashmere shawls (the great fashion accessory of the time) had also found their way into peasant dress (in a smaller size) from the mid- $19^{\text {th }}$ century, but by the late $19^{\text {th }}$ century, large cashmere and silk shawls (products of the European textile industry) became indispensable prestige items for all the multi-skirted costumes. There was also a definite emphasis on headdress. ${ }^{20}$

Multi-skirted costumes came with boots, ${ }^{21}$ alternatively with shoes from the 1920s-30s. The many heavy skirts swayed gently when walking, and girls learned how

17 In the case of Hungarian peasant dress, in regions with a rich costume tradition, there were hundreds of items in the wardrobe of a peasant woman (30-40 outer skirts, 20-40 festive aprons, 60-120 headscarves, etc.), from which many variations of outfits could be produced, pairing the materials, colors, embellishments according to certain rules.

18 In addition to the above-mentioned simple straight-cut "medieval"-type linen dress, another structural composition typical of Transylvania has retained Renaissance features: slimmer, elongated, anklelength skirt with apron, laced bodice or vest with Renaissance-cut embroidered shirt, red and yellow boots, a distinctive headband for virgins, tuille veil for newlywed women, etc. See, FüLEMILE 2010:171-172.

19 The voluminousness of the skirt was achieved not with hoops but with several layers of petticoats. The length of the skirt varied, falling more or less between the ankles and the knee. Aprons, especially in the $19^{\text {th }}$ and early $20^{\text {th }}$ centuries, were also wide. The petticoats required an enormous amount of fabric (made possible by the use of finer cambric) together with the wider apron and the skirt. Fashionable fabrics in the late $19^{\text {th }}$ century were red-patterned - called oily Turkish - and bluedyed printed cotton.

20 A good example is the folk costumes of the Palóc ethnographic region, a large territory in NorthEastern Hungary encompassing three counties, with many specific sub-regions. Palóc costumes are characterized by complex multi-layered headdresses with numerous variations for different age groups and occasions. Young married women wore different kinds of bonnets; older women used 3-4 layers of kerchiefs. With starched headscarves, they "sculpted" peculiar shapes, lending a distinctive local flavor to the look and making them immediately recognizable.

21 The boot fashion changed substantially. Instead of the older red, soft, knurly, folded bootleg, the new boot had a heavier, harder bootleg and employed the accepted western technique of sewing the sole. Black became the preferred color. (Generally, the more widespread use of black was an urban influence.) The more fashionable girls might require that the bootmaker make the sole creak. The sound of the boot could be amplified by copper "horseshoes" on the heels. 
to move the skirt rhythmically when promenading. Besides the new look, new styles of music and dance also became fashionable in these more innovative central regions in the $19^{\text {th }}$ century. The new musical styles, the csárdás (a couple dance accompanied by a gypsy string band) and the verbunk (a lads' recruiting dance), ${ }^{22}$ achieved widespread popularity across the entire kingdom, even influencing the music of non-Hungarians. ${ }^{23}$ This new type of dance, with lots of vertical movement, jumping, and leaping, was a perfect match for the heavy skirts. ${ }^{24}$

The style of peasant art in the period of capitalist industrialization and urbanization of the late $19^{\text {th }}$ and early $20^{\text {th }}$ century is referred to as the newest or latest style. Rural society was becoming increasingly stratified and impoverished, the people disillusioned. The agrarian poor mobilized and left their homes. Men worked as wage laborers on gigantic landed estates, did pick-and-shovel work on big railway constructions, became mining, industrial, or construction workers in the growing cities and went back and forth or emigrated to the New World. Unwed girls often served as domestic servants with middle-class families. Economic problems gave rise to individualization and inwardturning tendencies. Art became more secularized and took on increased entertaining functions. In this late, declining period, the compositions on painted furniture, textiles, and garments were dense with tiny motifs, and the continuous ornamentation covered the entire surface (e.g., on embroidered leather vests). The coloration changed, too, as factory-made dyes were more intense and vibrant, and instead of just primary colors, many shades of colors were available.

In women's wardrobes, the proportion of homespun material was radically decreasing, and the majority of textiles were factory-made: cambric, batiste, dyed printed cottonlinen, sateen, silk, cashmere, brocade, velvet, and even tulle. They keenly kept pace with the fabric supply. From the 1890s onward, the taste in fabric changed about every five years, and these fabrics could be found everywhere in the countryside. The difference was in how these fabrics were adapted to the local dress code. Jacquard-patterned ribbons, beads, sequins, machine-knit lace - products of the French, Austrian, Moravian, and Czech light industry - were used lavishly. ${ }^{25}$ At the same time, their own richly-applied handiwork, silk, cotton, and wool embroidery with specific local motifs, gave an extra 'couleur locale' to the attire.

22 The sound of the boot is an important "ingredient" of male dances, the rhythmic clapping on the hard bootleg along with the sound of the steps being an essential element in the interplay of music and dance.

23 A romantic interpretation of the csárdás-verbunk music by Liszt, Brahms, and others reached European concert halls; together with the Polish polka and mazurka, these essentially Hungarian dances were welcomed in elite European salons and even at the Viennese court balls.

24 In the culturally more conservative Transylvania, more archaic Renaissance style couple dances that incorporated a lot of turning and spinning were preserved. The women's smoother, more horizontal, even movements were aided by their longer, lighter skirts, which opened up like a flying circle, the centripetal forces of the skirt assisting the movement of the dancer perfectly. This type of spinning was unimaginable in the newer style multi-skirted type of heavier costumes.

25 By the late $19^{\text {th }}$-early $20^{\text {th }}$ century, every village had its own grocery store, run by local Jewish shopkeepers who shrewdly brought the needed fabrics to the locality. 
Padded, tailored, waist-length jackets, often with a ruffle around the waist, began to replace earlier furrier works. Jackets and blouses (replacing earlier shirt types) adapted and reinterpreted the cut of 19th-century fashionable pieces. The sewing machine became an important means of producing the more complicated tailored garments. ${ }^{26}$

The monetary value of the materials needed to compile the growing dowry increased by an almost unbearable rate. Along with the heavy burden of representation (grand dowry and grand wedding), families were pressured to choose birth control. ${ }^{27}$ With the introduction of female inheritance of land came an even more grandiose spending on the family's only daughter, whose extended wardrobe reached unprecedented limits. The ever-growing pressure of prestige competition created an exaggerated representation. This was a "suicidal" strategy that led either to bankruptcy or to the demographic depopulation of entire regions.

However, at the same time (around the first half of the $20^{\text {th }}$ century), a more urbanized dress began to replace the previously more peasant-oriented costumes in most regions. At the head of this process were the economically more innovative regions, Transdanubia in the West and the Great Plain area in particular. This more fashionforward dress, in most cases, still remained provincial: it continued to communicate the rural social background of the wearer and still carried the identity expression of "our costume." (Figure 2)

So overall, the frequent opportunity to meet with the "urban entity" had a bilateral effect. Urbanization and the abandonment of traditional costume started rapidly, while some of the insular regions continued elaborating their "peasant dress" 28 even in the interwar period. Encounters with urbanity, the possibility of seeing themselves in comparison, and the realization of the qualities of "otherness" sharpened their consciousness and intensified artistic production and the invention of the "self." Their increased social self-pride was expressed in the sophisticatedly elaborated sartorial system. It is like a magnifying glass. Before stepping forward and leaving tradition behind, they consciously manifest what they are; only then comes the avalanche-like change - a cultural logic which contradicts our general stereotypical vision of the effects of urbanization.

Of the declining number of communities that still chose to retain traditional dress, many could not afford to buy the expensive fabrics and accessories. What they could not afford, they supplemented with their own creativity and handiwork. From the early $20^{\text {th }}$ century, but especially since the 1920 s, a new style of needlework emerged in these communities on white cotton cambric with white and/or colored mercerized cotton yarn, often using an open-work technique. Flowers, using many shades of colors, covered more and more of the surface of the fabric of aprons, vests, and bonnets. As a result of this very inventive period, characteristic regional late styles evolved

${ }_{26}$ The sewing machine also became a tool of decorating the flowing contours of embroidered motifs with colored twisted cotton yarn.

27 Strict birth control and one-child system as an economic strategy was practiced especially in Reformed Presbyterian regions, i.e., Ormánság, Sárköz, Kalotaszeg. (In 1910, two-thirds of Hungarians were Catholic, one-third Reformed Presbyterian.)

28 Peasant dress is the expression preferred by locals when speaking of "our costume," which they consciously contrast with "urban fashionable dress." 
(Kalocsa, Sióagárd, the Galga river valley near Budapest), out of which Kalocsa gained the greatest tourist fame. ${ }^{29}$ (Figure 3 )

In this last period, men often abandoned their traditional costume and changed to urban dress earlier than women. On account of a lengthy service in the army, World War I "swept away" the traditional male clothing of many regions. On the other hand, women's clothing remained in the focus of the prestige aspirations of male society, and men continued to express their social and local identity through their wives and daughters. From this time on, clothing became more and more a gendered expression, as men's and women's style of clothing diverged. (Figure 6, 7, 10,37) A moral double standard became more prevalent as men had more mobile, outward-turning lives, while the women's role in preserving traditional values became more emphasized. Other aspects of life under female authority (clothing, household furnishings and textiles, kitchen, child rearing, practices and beliefs concerning spells, health, and birth) remained traditional for as long as women retained their traditional dress.

On the other hand in some cases it can be seen that although women stayed within the traditional framework of expression, they gained enormous mobility by commuting, trading, and traveling to more distant places in order to sell home-craft products, for example. Women thus controlled the extra income, which often increased their scope of authority within the family itself.

29 Despite its relatively short history in the $20^{\text {th }}$ century, Kalocsa's embroidery is popularly considered to be the essential Hungarian style. By the second half of the $20^{\text {th }}$ century, patterns taken from needlework were applied on kitschy gadgets of "airport art" chinaware in industrial quantities as well. These objects are also at the core of the nostalgic souvenir collecting of older generations of heritage communities. 


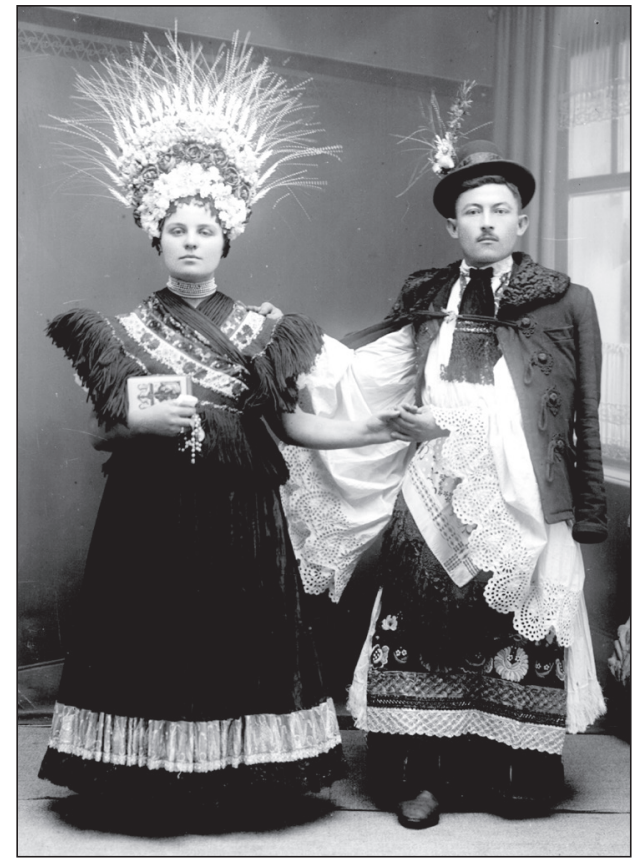

Figure 1. An example of a peasant-style, typically local folk costume from Mezökövesd, famous for its folk art. Matyó groom and bride, early 20th century, Mezőkövesd (Borsod county) (Photo Collection of Museum of Ethnography, Budapest, inventory number: NM F 27650)

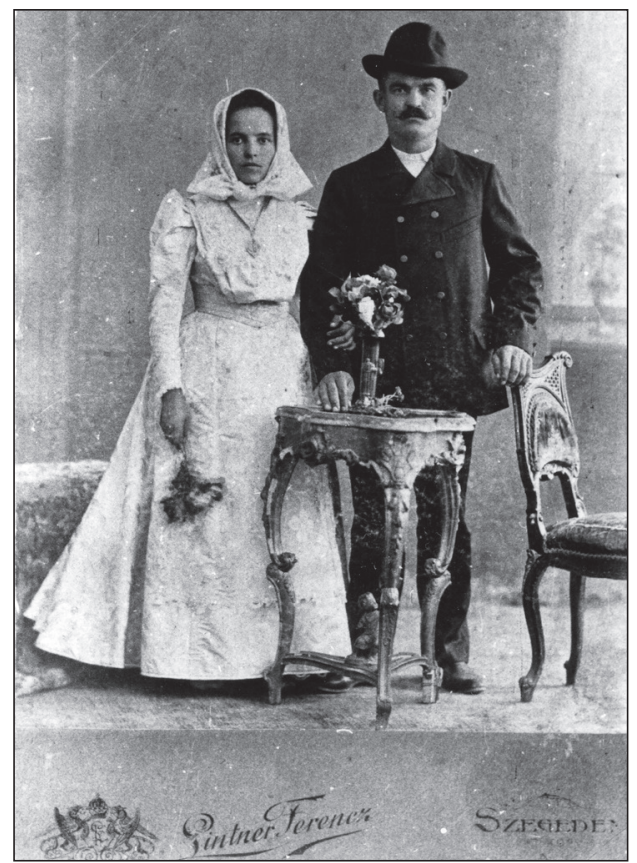

Figure 2. An example of a peasant-burgher style dress of market towns on the Great Plain. Young couple, early 20th century, Szeged-Alsóváros, (Csongrád county) (Photo Collection of Móra Ferenc Museum, Szeged, inventory number: 14265)

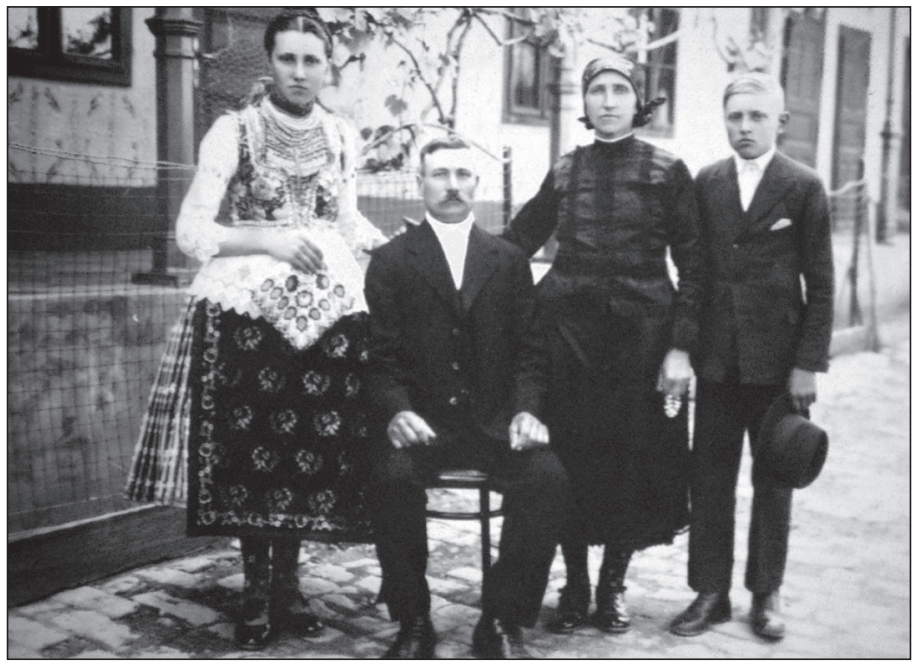

Figure 3. Peasant family in Sióagárd (Tolna county), second half of the 1930s. (Photo privately owned) 


\section{LOCALITIES STUDIED, RESEARCH SOURCES AND QUESTIONS}

After this brief overview of the development of peasant clothing in Hungary, I would like to turn to the description of my fieldwork-based research method, because only with the knowledge of the above can one understand the aspects that guided my choice of collection sites and the issues I focused on.

Between 1983 and 1988, I collected in about thirty-five Hungarian villages as part of the research project. ${ }^{30}$ (Figure 4) There is a village in northern Hungary, Kazár in Nógrád county, where I kept returning over a ten-year period to continue my fieldwork. I also kept returning to a village in Transdanubia, Sióagárd in Tolna County, for about three years. In addition to these, I also carried out more thorough collecting in several villages because they proved to be of model value in some respect (Apátfalva, Bag, Bogyiszló, Madocsa, Mezőkövesd, Regöly, Szakály, Szebény, Szeremle, Varsány, Zengővárkony, Zsámbok). In the remaining settlements, I carried out a few days' worth of exploratory collecting, partly to find examples that stand out with their model-like nature, and partly to ensure that the diverse data obtained from many places provide a reliable basis for comparing and classifying the phenomena. Knowing these, I was able to recognize and formulate certain seemingly more general characteristics or unique specifics. Although I tried to capture the tendential phenomena, I must emphasize that reality is diverse, no two models are identical in every detail, and the process of change has taken on a unique character everywhere.

Observations of live situations, conversations, the articles of individual local wardrobes, and family photos provided a wealth of information. Descriptions from museum repositories, sporadic data from decades-old collections of others, findings gleaned from photographic materials, as well as some archival sources have expanded the diachronic historical dimensions of the research. ${ }^{31}$

${ }^{30}$ Ethnographic fieldwork: Bogyiszló, Csibrák, Decs, Dúzs, Madocsa, Regöly, Sióagárd, Szakály (Tolna county); Hosszúhetény, Martonfa, Szebény, Zengővárkony (Baranya county); Érsekcsanád, Szeremle (Bács-Kiskun county); Acsa, Bag, Galgahévíz, Galgagyörk, Galgamácsa, Hévízgyörk, Szada, Tura, Vácszentlászló, Zsámbok (Pest county); Galgaguta, Hollókő, Kazár, Mátraszele, Mátraszőlős, Mátraverebély, Nógrádkövesd, Varsány, Vizslás (Nógrád county); Mezőkövesd, Szentistván (BorsodAbaúj-Zemplén county); Apátfalva, Szeged-Alsóváros, Tápé (Csongrád county).

In addition to the mentoring of Edit Fél, Jolán Borbély, Márta Kapros, and Mária G. Vámos also assisted me in finding my way in the field. Márta T. Knotik shared with me the findings of her data collection on the clothing of Szeged-Alsóváros. Hereby I would like to thank them again for their assistance.

31 Research in historical archives and museum textile, photo and data repositories: Baja, Balassagyarmat, Budapest, Eger, Pécs, Salgótarján, Szeged, Szekszárd. (Figure 4) 


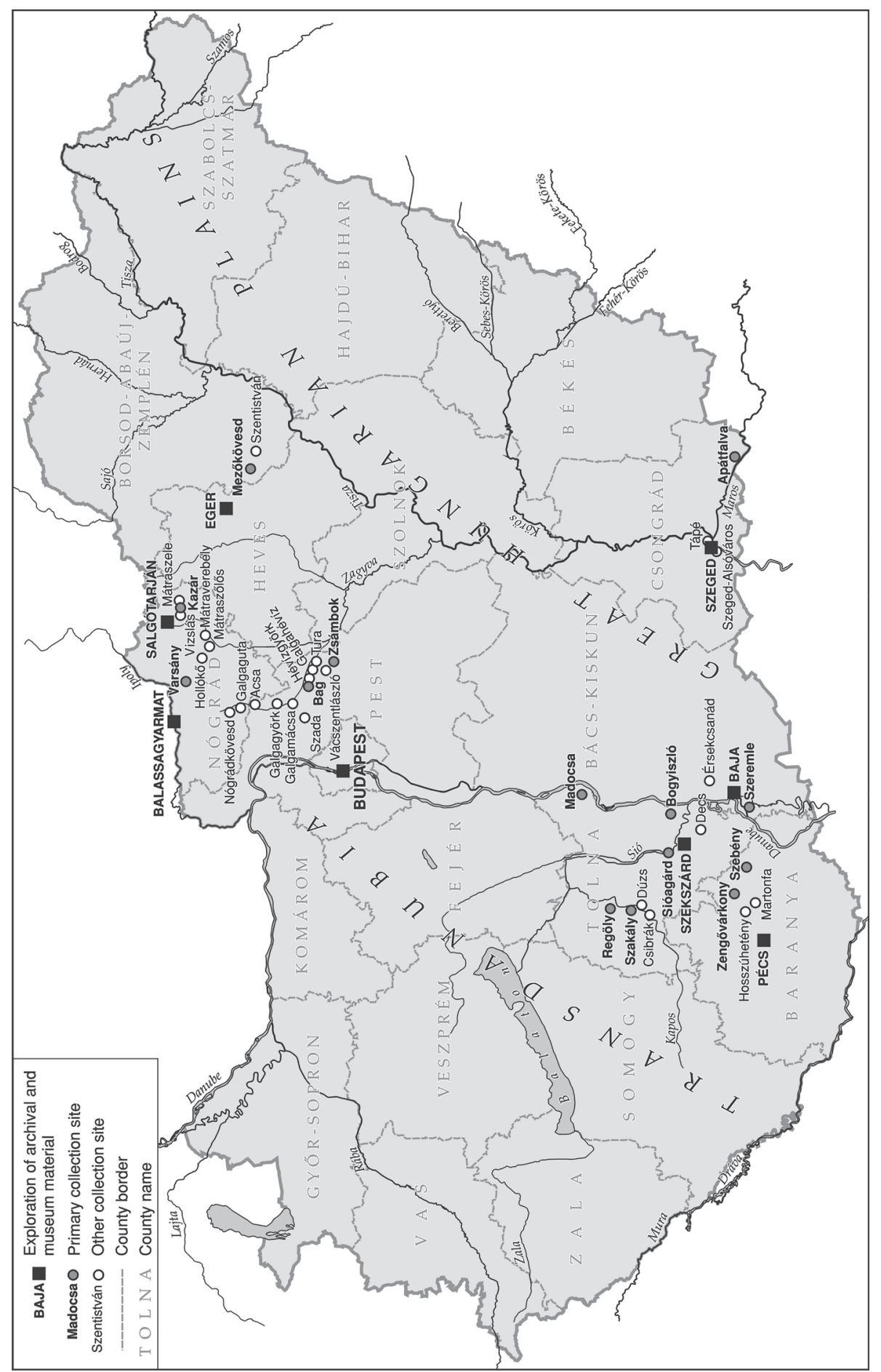

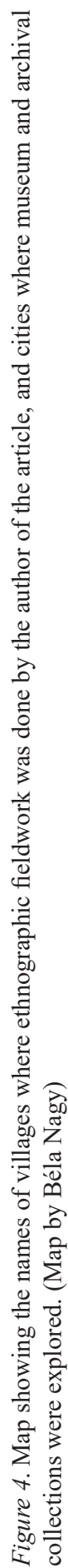


In the 1980s, I visited the areas of neighboring Romania inhabited by Hungarian minority groups quite often, especially in Transylvania. During the restrictive period of the Ceausescu era, when border traffic was strictly controlled, I attended weddings, dance parties, community and church events in many villages where traditional dress was still worn and observed traditional clothing practices and attitudes toward tradition. Therefore, I had more thorough impressions, but I couldn't start a systematic collection at that time due to the political atmosphere and the anti-Hungarian administrative regulations at the level of the state apparatus. ${ }^{32}$ Due to the different political and economic environment, the different logic and motivations of preserving traditions, ${ }^{33}$ it was not even my goal at that time to compare Hungarian and Transylvanian examples - I primarily sought to model and understand the logic of processes in Hungary.

The studied communities could be classified into certain types and models in terms of their social stratification, livelihood, economic strategies, and mentality. In most cases, the local costumes acquired a special formal character and an elaborate system of meaning (costumes of the Palóc, Sárköz, Matyó ethnographic groups) in the late $19^{\text {th }}$ early $20^{\text {th }}$ century, during the late peasant flowering of folk art (see above). There were some examples among the studied villages whose multi-skirted costume and embroidery culture (colored cotton embroidery on white cotton canvas, covering almost the entire surface) represented the so-called "latest" $20^{\text {th }}$-century style of folk art (Sióagárd, Galgamente), and whose costume flowered in the interwar period.

In each of the villages I studied that still had typical wear in the 1980s, there was a special economic base in the past which allowed the typical dress culture to flourish: coal mining in Kazár; railway work in Bag and Tura; ${ }^{34}$ intensive horticulture and selling produce in the city's foodmarkets in the Galga river valley near Budapest, or in Sióagárd near Szekszárd, the county seat. "A relatively late economic differentiation facilitated the rise of these villages from the average peasant existence of the surrounding regions and at the same time made them more prosperous than their surroundings through their horticulture and vegetable production. Their way of life that involved frequent visits to urban markets has increased their mobility and urban connections..." (HOFER - FÉL 1975:52-53).

In addition to these examples of markedly "peasant taste", I also examined the process of dress change in the more fashionable peasant-bourgeois type dress of some of the formerly prosperous villages (Apátfalva in the Southern Great Plain, Madocsa on the Danube, and two settlements in the Kapos river valley). Although the abandonment of local costume took place during the study period, the nature of the process differed from the changes mentioned above for the costumes of specifically "peasant taste." In

\footnotetext{
32 I commenced more regular fieldwork in Transylvania in 1991, which I and my husband, Balázs Balogh, still continue today, mainly in Kalotaszeg and its wider surroundings, as well as around Cluj-Napoca, where we have collected in about 100 settlements in the last 30 years. See for instance: BALOGH - FÜlEMILE 2004, 2006, 2012.

33 There are regions of Hungarian minority groups in Transylvania where several communities preserved a more "archaic" stage of folk dress, along with lively cultural practices, elaborate functions and occasions, rich symbolism, and an array of recent manifest meanings of ethnic costume. Revival phenomena are often stronger among them, and ethnic dress was and still can be used as a conscious marker of recent minority, ethnic, and national identity.

34 For the latter, see FÉL 1937:96.
} 
these villages, the relationship to costume was fundamentally different, substantially more rational than in communities with characteristically "peasant" folk costumes. (In Apátfalva, for example, women did not embroider, as in many other places. It was considered "a waste of time, without value," "we've lived in it, we don't want to see it.")

Ethnographers with relevant field experience studying Hungarian peasant society and culture are aware of the phenomenon that certain communities can also be characterized by the place of clothing in their value system. "The structure of the local system of objects (household articles and tools) is the result of choices and decisions about what's important, irrelevant, worth sacrificing or deploying the limited reserves of one's own energy and material resources for" (FÉL - HoFER 1969/a:34). Bertalan Andrásfalvy also drew attention to the same in his study on the costume of ethnographic groups in Southern Transdanubia. "Monetary value and apportioning are only one aspect of clarifying the place of something in the order of values; it is much more important and allows us to get to know the studied ethnic group better if we look for how much other content the costume is meant to express and carry" (ANDRÁSFALVY 1979:213-214). ${ }^{36}$

\section{An example of a specific locality and the fieldwork method}

Regarding the methodology of the research, it is worth mentioning a specific example in more detail. Kazár in Nógrád county belongs to the Palóc ethnographic group famous for its folk art. The village is located $7 \mathrm{~km}$ from Salgótarján, an industrial and mining center that was rapidly industrialized around the turn of the $20^{\text {th }}$ century, gained city status in the 1920s and county seat status in socialist times. Kazár also entered coal mining early on. A mining colony was built on the outskirts of the village in the first half of the 1920s. The urbanized miner population of the Telep (Colony) aroused aversion, resentment, and disassociation in the peasant inhabitants of the village. For the villagers, the extra income from mining allowed their folk costume, which reflected a markedly peasant taste, to flourish and manifest their peasant status and identity.

This costumed village became an archetypical case study for me, a site of intensive learning. (Out of the 35 villages examined in the framework of the research, I spent the longest period in Kazár. This is where I got acquainted with the topic of peasant clothing and within it the modernization and abandonment of traditional costume, and where I developed my research questions and methods of collecting.) My co-author and

35 A value system means conscious decisions about what is considered important, which aspects of life money, energy, time, and resources should be spent on, and what areas of culture should be pursued and emphasized. In general, when it came to personal comfort, there was a high rate of selfdenial, although generous sums were being spent on prestige representations. Hungarian peasants laid particular emphasis on everything external that was visible and justifiable to the community. The quality of a horse-team and its harness were as much a matter of prestige and self-pride for the head of the family as was a large wedding (lasting three days and with hundreds of guests). The most important means of prestige representation was clothing.

36 Bertalan Andrásfalvy's outstanding work on peasant values and mentality is the study in which he juxtaposes the elements of the strongly divergent values of the Hungarian peasant community of Hegyhát in Southern Transdanubia and the neighboring Swabian German peasant community, pointing out the underlying historical social and economic reasons (ANDRÁSFALVY 1978). 
I approached the entire age group of women in the village who wore folk costume, about 100 women who were then over 50-55 years old.$^{37}$ We knew all of them personally, interviewed them, surveyed their wardrobes, tried to reconstruct the processes of the dress change, the motivations, emotional charge, and narratives of retaining tradition. Additionally, we also discussed the circumstances, motivations, and reasons behind the decision to abandon folk dress by the female age group who were born into peasant costume but abandoned it as a young adult, their attitude towards the "ideology" of innovation and towards the abandoned folk dress.

Nevertheless, we also tried to develop an optimal form for a local dress monograph in which we tried to capture the entire complex knowledge and material world of clothing in this community with a rich costume tradition in diachronic and synchronous sections, in its social stratification. ${ }^{38}$ We did not begin our description with the oldest reconstructable period, but rather captured the richest, most complete period of the symbology of folk costume - the interwar period - in its own complexity, and used it as a basis of comparison to present the characteristics of the preceding and subsequent periods. In addition to the encyclopedia-like knowledge base of types of articles attached to the main text, tables presented the variations of pairing types of articles, textures, and colors, i.e., the specific governing principles of outfit configuration, the transition process for integrating innovations, the ideal (middle peasant) dowry that characterizes each era, the sources of acquiring costumes, and the ways of caring for and storing the garments.

We tried to interpret the clothing system not only in its local context but also in its wider social context, and to understand how and why the abundantly rich system of women's costume was encouraged and maintained (even financially) in a peasant community where the men began working in the nearby coal mines opened in the late $19^{\text {th }}$-early $20^{\text {th }}$ century - albeit as seasonal workers - and therefore abandoned the style of

37 The co-author of the Kazár collection was Judit Stefány, my university classmate. The ethnographic material of our Kazár collection provided the basis for our MA thesis and later doctoral dissertation, which was also published as a book (FüLEMILE - STEFÁNY 1989).

38 In the case of regional folk costumes, public opinion is influenced by the schematism that lay people develop because of the unavoidable didactic simplification of museum displays and popular publications. Many people have a stereotyped, fixed image (a certain landscape $=$ a flashing image $=$ a certain kind of costume), and they have no idea of the variety of form, of the range of possible variants the dowry, the wardrobe provides for an individual to wear throughout their lifetime, not to mention the gamut of variations in the local community.

The sociology of costume readily employs the concepts of structuralist linguistics as a metaphoric parallel in approaching the traditional clothing systems of premodern hierarchical societies. Roland Barthes examines the methodological relevance of applying the Saussurean model on the study of dress in the chapter "Langue and parole, dress and dressing" in History and Sociology of Clothing: Some Methodological Observations (BARTHES 2013:8-11, originally published in Annales 3 (JulySept.) 1957, 430-41). As he states: "Since Saussure, we know that language, like dress, is both a system and a history, an individual act and a collective institution...” „Langue is the social institution, independent of the individual; its a normative reserve from which the individual draws their parole, 'a virtual system that is actualized only in and through parole'. Parole is the individual act, 'an actualized manifestation of the function of langage', langage being a generic term for both langue and parole. It seems to be extremely useful, by way of an analogy to clothing, to identify an institutional, fundamentally social reality, which, independent of the individual, is like the systematic, normative reserve from which the individual draws their own clothing..." (BARTHEs 2013:8) 
dress expressing their peasant status much earlier, after World War I. ${ }^{39}$ How the colorful folk costumes of their wives and daughters served as a continuing means of expressing their peasant social identity, of social representation - markedly contrasted with urban and mining/industrial life - and as a kind of illusion of the "world" which the men were forced to abandon. ${ }^{40}$ (Figures 5, 6, 7)

That structuralist pair of terms is an excellent tool to illustrate the complexity of the richly differentiated clothing systems of the local peasant communities of East-Central Europe in the late $19^{\text {th }}$ and early $20^{\text {th }}$ centuries. The "langue', the "normative reserve" of the dress system involves vocabulary (objects) and grammar (knowledge). Words in the "dictionary" of costume are the totality of possible consentaneous articles in an ideal wardrobe (garments, fabrics, colors, patterns, embellishments). The "grammar", the complex knowledge and practices in a local dress culture, includes the "syntax", the rules by which these elements are arranged by the wearer into outfits - depending on the occasion, age, gender, marital status, rank, and other special content one wishes to express - as well as all the wealth of information related to the acquisition, production, cleaning, and storage of clothing, and the care and aesthetics of the body. 'Parole', the spoken text, the speech of dressing, the set of clothes worn by the individual for a particular occasion, is situation-dependent and contingent, the content, rhetorical devices, and style of which depend on many things - the background of the speaker/wearer (social affiliation, education, age, gender, taste, etc.) as well as the specific occasion, purpose, and medium of speaking/appearance. The physical, material, theoretical, and bodily knowledge needed for clothing, as well as the variations and the implementation in situation-dependent social practice, together with the meanings that can also be decoded in social communication, all make up the general phenomenon of 'langage', the complex whole of the clothing system.

39 In Kazár, for example, traditional men's wear disappeared in the first half of the 1920s. The people of Kazár believe that the men's wear was "swept away by the mine." (The most dynamically changing period in Kazár men's wear was around 1890-1900, when several types of clothing were present side by side in the older and younger generations, but at the same time the initial signs of costume abandonment were already showing. In Kazár women's clothing, it was the 1930s that were characterized by a similar complexity.) The dissonance between men's and women's clothing was clear to them, too. "Short wide skirts and pantaloons do not go together," they said. In the interwar period, the situation was similar in most of the villages studied.

In Apátfalva in the Southern Great Plain, which is of the peasant-bourgeois type, the situation was reversed. Here, women's abandonment of folk costume started around 1920 (the latest in Csongrád county) and ended quickly, within 10 years. On the other hand, the clothing of men over the age of 40 had conspicuously traditional characteristics even in the 1980s. Different generations wore different types of clothing, and the older the men, the more they preferred traditional garments. (Interestingly, until the 1980s, a Slovak tailor from Orosháza would show up at the market in Apátfalva every two weeks with serge and wool Sunday suits and corduroy and blue linen casual and work clothes that appealed to local farmers with more provincial tastes.)

40 Even after finishing the costume monograph, we kept in touch with our informants for years and worked on new projects. One of our main informants, a woman who had been widowed early and had an exceptional wardrobe and knowledge, not only assisted in writing the monograph on the attire of her village but was also the main subject of a documentary produced by the film studio of the Museum of Ethnography (László Lehel - János Tari - Ágnes Fülemile - Judit Stefány: Women's wear in Kazár. A film from the Ethnographic Film Studio of the Museum of Ethnography. 45 mins). Later on, at our encouragement, Aunt Panni, who was blessed with irresistible humor and was an excellent raconteur, wrote an autobiography, along with the stories of the village community and her family - a striking account of the peasant world and its values - which we edited and had published in several editions (TőzsÉr KAPCSOS 2004). (Figure 7, 24, 43) 


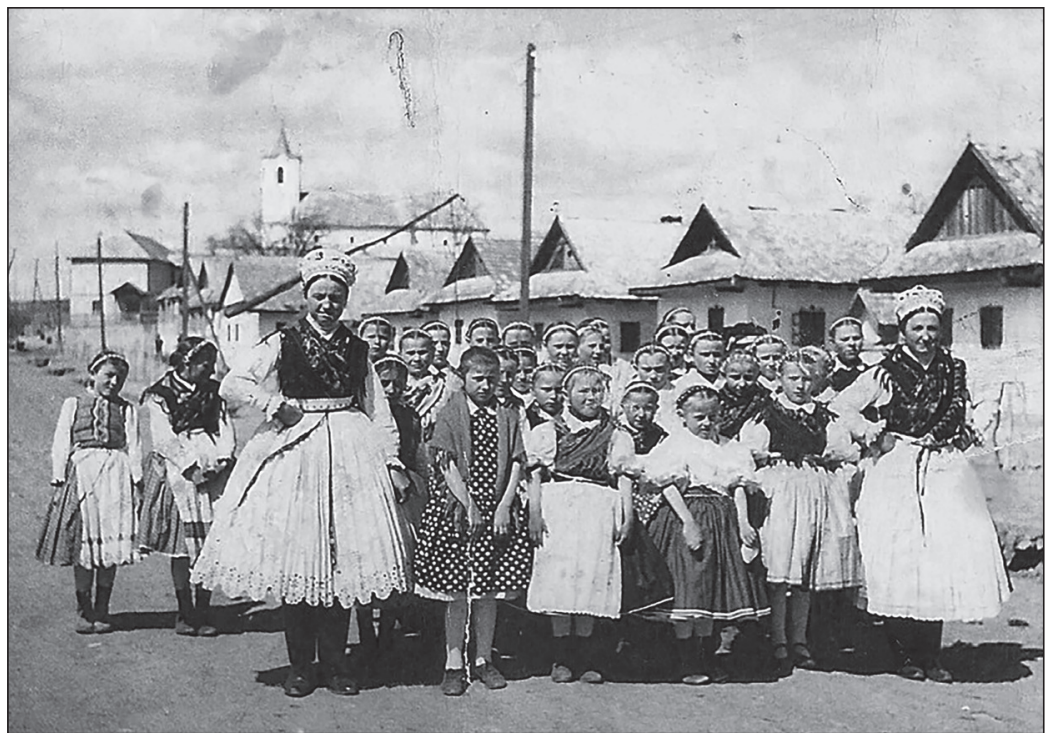

Figure 5. Elementary school students, main street of Kazár (Nógrád county), mid1930s, (Photo privately owned)

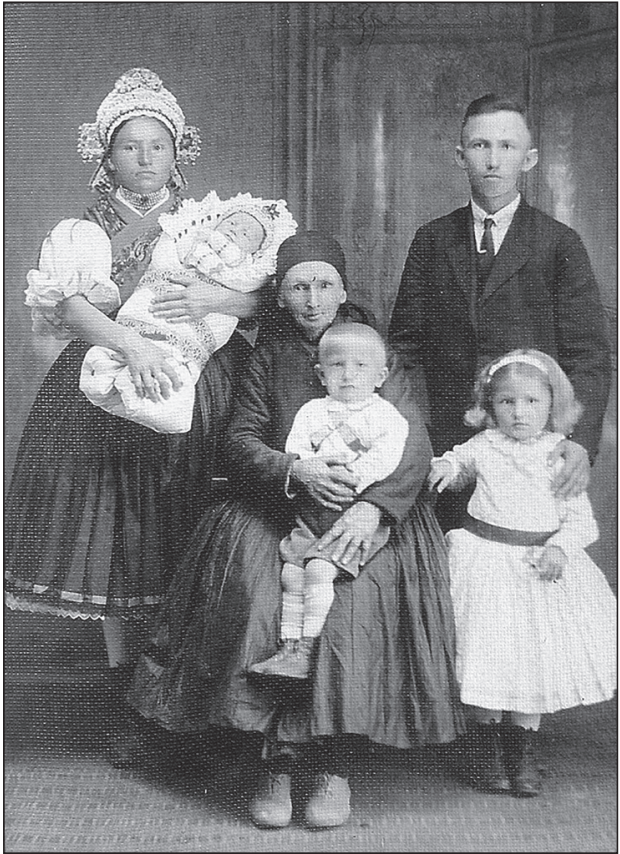

Figure 6. Family in the 1920 s with women in costume and husband and children in urban clothes, Kazár (Nógrád county) (Photo privately owned)

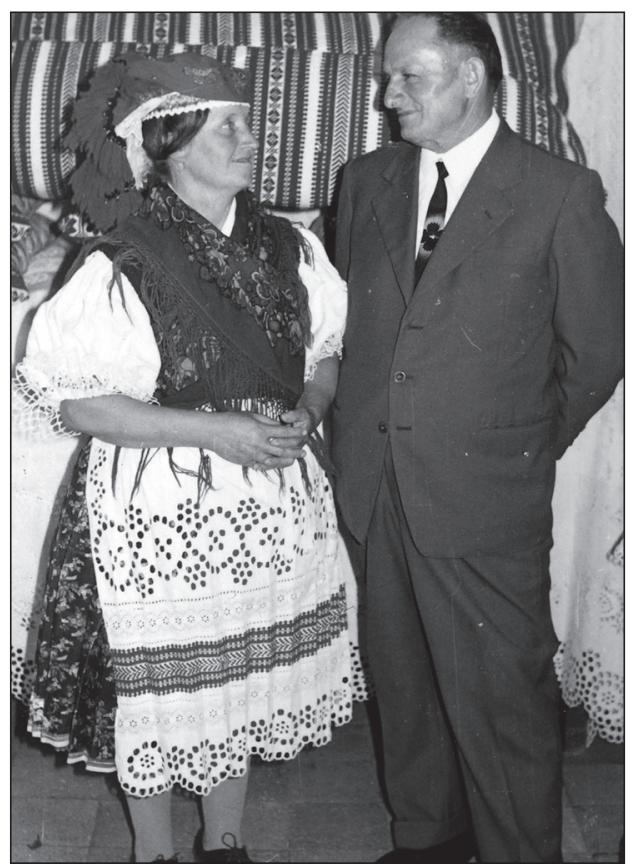

Figure 7. Ernő Kovács Palya and his wife Aunt Panni in the clean room of their house. Kazár (Nógrád county), second half of the 1970s, (Photo privately owned) 


\section{MAJOR PERIODS OF FOLK COSTUME ABANDONMENT}

\section{Period: 1920 s and 1930 s}

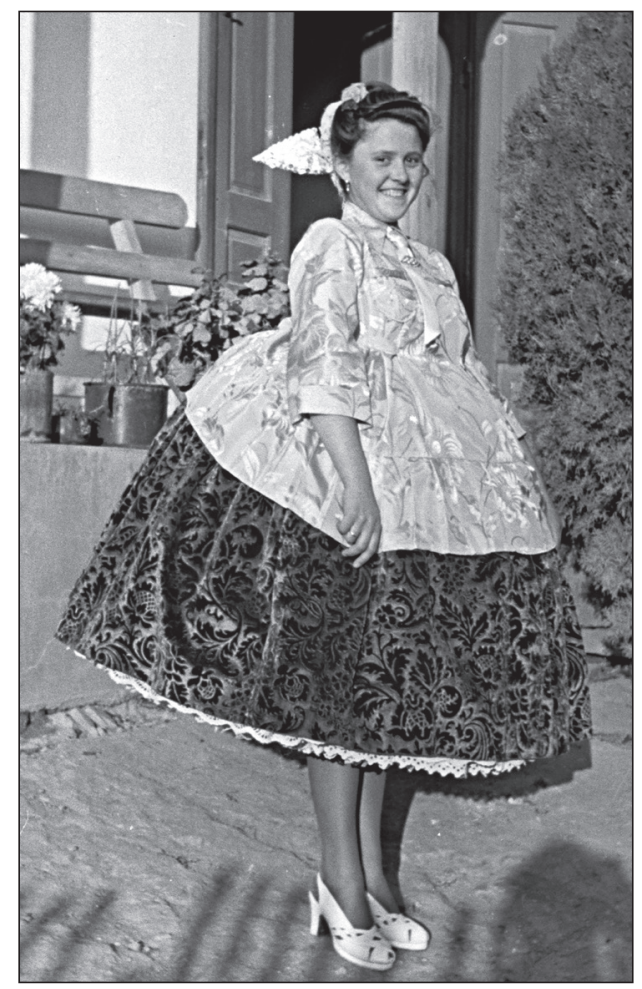

Figure 8. Multi-skirted costume from along the Kapos-Koppány. Young bride in her Sunday best and a pille (butterfly) headdress, 1953. She was still in costume, even though the village had largely abandoned folk dress by 1953. Bedeg (Tolna county) (Photo by Tamás Hofer, Photo Collection of Museum of Ethnography, Budapest, inventory number: NM F110094)
The 1920s and 1930s played a key role in the stylistic development of the clothing of peasantry. Several processes were present simultaneously. On the one hand, in villages where traditional peasant dress was in its high period, the costumes flourished, became colorful and overly embellished. At the same time, the idea of abandoning folk dress also emerged in these places by this time, although only in the form of sporadic cases, individual experiments. In other, more embourgeoised areas, where the local character of clothing was not so robust, this is the main era of shift in style from local traditional wear to urban fashionable dress. Thirdly, there was a wave of general fashion change across the country in villages with peasant folk costumes, manifested in the pursuit of a new aesthetic, new silhouette, the proliferation of new garments, and, at the same time, the displacement of certain oldfashioned garments and styles. Changes in clothing, whether seen from the perspective of pursuit of fashion trends or the fact of costume abandonment, nonetheless indicate the spread of the urban model.

The major periods of simultaneously emerging changes in the style of peasant clothing that could be interpreted as effects of fashion and were observable throughout the country included the turn of the 20th century, the 1920s-1930s, and the 1950s. Changing fashions also left their mark on the "famous" folk costumes, albeit in less consequential ways. Fashion trends, however, were more pronounced, more homogeneous in areas (and most of the country could be considered as such) where typical "peasant" folk costumes did not develop, but clothing, although less tied to place, nonetheless reflected peasant tastes.

The essence of the fashion change of the 1930s was the following: colourful tailored blouses were favored over old-style linen or cotton shirts, bodices and shoulder shawls; knitted cardigans and sweaters over fur- and cotton-lined waist-length jackets. Boots may get replaced by shoes, the intricate, multi-layered headdresses and Biedermeier 
hairstyle by pulled-back hair and simple buns instead of braids. The apron may have been omitted from the festive attire. ${ }^{41}$ Most important was the radical change of the silhouette. The slimmer, long-skirted, bell-like silhouette of the turn of the century was replaced by a silhouette that emphasized shoulders and hips. In some places, shoulder and bum pads were used, which made it possible to "sculpt" an ideal silhouette and exaggerate anatomical proportions to an extreme. The skirt became shorter and wider. ${ }^{42}$ (Figure 8) The new type of clothing and silhouette was most prevalent in the costumed villages of Southern Transdanubia (Kapos river valley, Sárköz). (Figure 9)

The above tendencies of change can be observed in typically "peasant" costumes as well, albeit more uneven, more or less successful. For instance, the blouse may have appeared as a fashionable garment in some places, while in other villages it may have been considered a "rational/practical," "cheap", or "substitute" solution, without gaining momentum. ${ }^{43}$

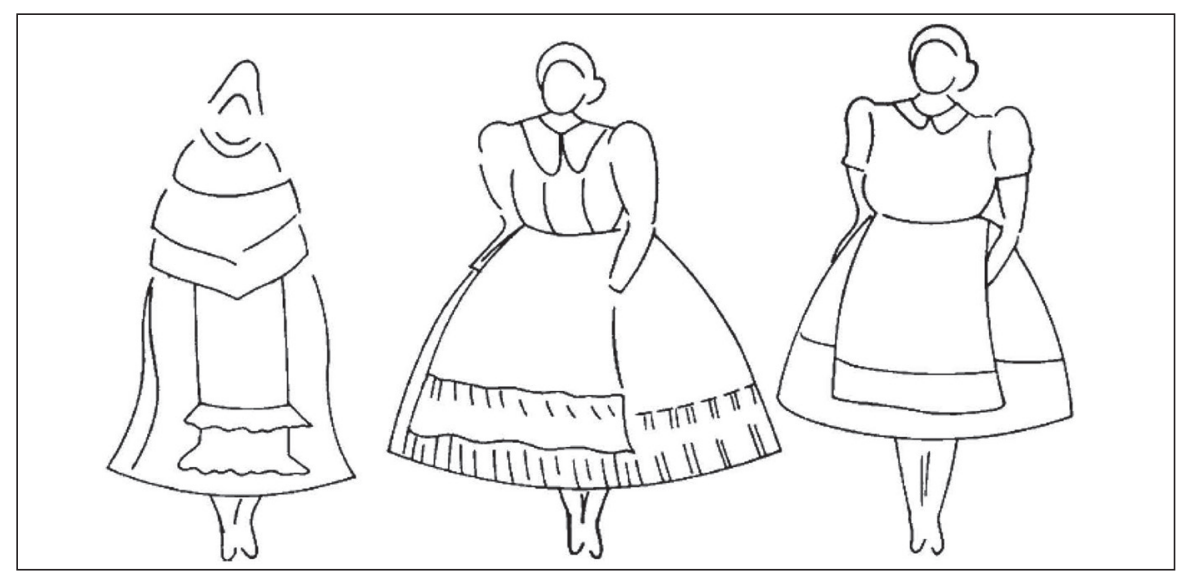

Figure 9. The development of the silhouette of the Zengővárkony (Baranya county) costume, based on family photos: 1910s, cca. 1935, 1950s. (Drawing by Ágnes Fülemile)

41 For example, in Örhalom (Nógrád county) FéL 1962:30, on the Kapos river valley, G. VÁmos 1977:8-9, 21-22; 1979:242-45.

42 Many regional Hungarian women's dresses emphasized wide shoulders, wide hips, and strong legs, signs of the sturdiness of a healthy body. If a woman was somewhat slim, she added (without admitting it) extra padding at the hips and some extra layers of petticoats. The folds of the skirt accentuated the bottom and the sides, never the front. The belly had to be flat. While shoulders were emphasized, the form of the breasts was not meant to be displayed. In line with the general work ethic, strong and ablebodied boys and girls who were supposed to be hard workers and able to give birth to healthy children were valued. Round-faced, rosy-cheeked girls met the beauty ideal, and brown hair (anthropologically dominant within the Hungarian population) was considered pleasing. Pale, blonde girls of a slim and fragile stature were teased as "weak, finicky urban girls" unfit for hard work.

43 The blouse has captivated the entire community in some villages, e.g., Mátraszele, Hosszúhetény. In Hosszúhetény, they say "we switched to lighter wear." Elsewhere, the blouse was raised only as an idea, which was not accepted by the community as a whole, but proved to be a "substitute" solution for certain strata; in Kazár, for example, the blouse was worn only by the poor and orphans, "who had no other choice." Because it was considered "cheaper," it had no prestige, it gained no traction. In Bag, it was also the poor girls and women who worked on the railway or as farmhands that were the first to abandon the shawls, boots, and traditional hairstyles and headgear. In Bag as a whole, this solution spread only later, in the 1950s, but in Kazár, for example, it was never adopted. 


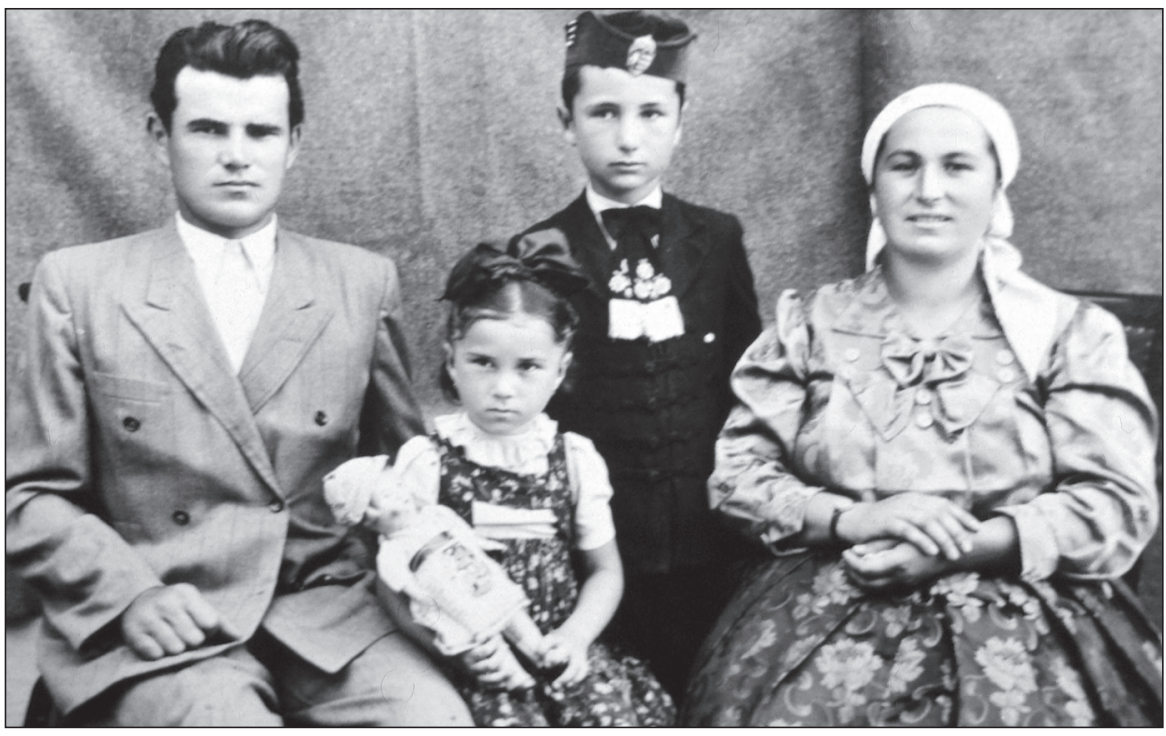

Figure 10. Family around 1946 in Zengővárkony (Baranya county). Wife in costume, husband in suit, little girl "halfway" - the ruffle, floral fabric, and ribbon still reflect a costume style, but the tailoring of the dress is already urban. Boy in a Hungarian "Bocskai suit" with the old historical coat of arms on the shako, which was no longer worn as a school uniform after the communist political turn of 1948, and the use of the coat of arms also changed in 1949. (Photo privately owned)

The 1950s marked a critical period in the history of peasant costume. Surprisingly, it was not World War II that was the main reason for the abandonment of folk dress. (The destruction of physical objects was more of a problem in the immediate vicinity of the front line, where civilian settlements were exposed to more damages.) Although World War II was a cataclysmic upheaval, it did not bring about a direct change in social structure, mentality, or culture. The post-war economic situation, financial and raw material shortages - albeit pre-existing - were neither the triggers nor the primary causes of the abandonment of peasant costume. On the contrary, with the agrarian reform of $1945,{ }^{44}$ a "re-peasantization" phenomenon emerged. (Figure 10) In fact, due to the post-war land reform, the material base of the smallholder peasantry as well as

44 One of the biggest problems that came with the social tensions in the interwar period was the unresolved issue of land. The Land Reform bill was introduced in Hungary in the last weeks of the war, in March 1945, under the tutelage of Soviet troops, and the process was completed by the fall of 1946. (Alongside the radical land reform of 1945, they wanted to involve the peasantry in the restoration of war-damaged production.) The holdings of large landed estates were confiscated and split into smallholdings - one third of the arable soil in total. (Allowances were limited to 100 acres for previous landowners, 200 for peasants, and 300 for confirmed antifascists.) 
classical middle peasant values and mindset were somewhat reinforced. ${ }^{45}$ If there was abandonment of folk dress in the second half of the 1940s in some places, it was a continuation of a process that had started before the war.

In the 1950s, however, a solid process of costume abandonment commenced. The robust wave of acculturation is not, or not primarily, due to the changed living and working conditions -, after all private ownership of peasant land still prevailed - yet a contradictory cultural process began nonetheless, the root of which can be found, directly or indirectly, in the peasant policies of the era.

After the brief democratic period between 1945 and 1948 came the harsh dictatorship with the oppression of the prosperous peasantry. The political change of 1948 with the communist takeover of power immediately introduced soviet-type, intolerant, antipeasant policies. ${ }^{46}$ Persecutions, kulak blacklists, imprisonment, deportation to labor camps, political trials, and coercive requisitions marked the period. (Figure 12)

As part of the communist turn, for political reasons, a forced collectivization based on the Soviet model commenced in the second half of 1948, which was met with major disapproval among farmers who had just been reinforced in their sense of ownership by the land reform. The Communists tried to force entry into cooperatives by all possible means. ${ }^{47}$ The escalating agitation was accompanied by demagogic press propaganda and economic and physical coercion. The increased tax burden on the peasantry and the compulsory contribution of crops was a heavy burden. ${ }^{48}$ The unattainable quota system and the "intensifying class struggle" brought about the incorporation of criminal law instruments into agricultural policy. ${ }^{49}$ One instrument of fearmongering was the increasingly shameless "dekulakization," which sought to eradicate the best of a successful, highly respected farming society. ${ }^{50}$

The land reform provided 650,000 claimants with support (creating 400,000 new individual holdings and supplementing 240,000 existing holdings). Poor families (mostly landless wage workers and farmhands) were given a smallholding not exceeding 5 acres. Compared to the 1941 statistics, the proportion of landless people decreased (from 46 to 17 per cent), and the dwarf and smallholder stratum within the peasantry became dominant (increasing from 47 per cent to 80 per cent).

However, the intolerant implementation of the process led to many conflicts and grievances. These newly-created dwarfholdings were not even enough for self-sufficiency, and a lack of animals and adequate tools and machinery often made cultivation of the land difficult. With the forced disintegration of larger agrarian enterprises, the fragmented land structure did not lend itself to sensible, rational farming but instead reinforced the old, traditional methods.

45 The sociological literature also deals with the "re-peasantization" characteristic of 1945-48. Füstös et al. 1982:329.

46 For the peasant policies of the late 1940s and 1950s, with a critical voice already during the Kádárera see, for example, Donáth 1977; SimOn 1984; BAlOGH - PÖLÖSKeI 1975.

47 In 1949-1950, practically all members of production cooperatives came from the poorest of the village populations, which is why the early kolkhoz-type cooperatives held no prestige. After Stalin's death in 1953, the personal cult of Mátyás Rákosi became compromised, and during his first term as prime minister, Imre Nagy allowed people to leave these early, rather unsuccessful cooperatives; in 1955-56, however, forced collectivization returned, which partly motivated the rural events of the anti-soviet revolution of 1956.

48 On the value of work, quotas, contributions, prices, see Chapter 7: "Administering Coercion" in: LAMPLAND 2016:325-380, in Scribd online edition.

49 Between 1949 and 1955 , more than 400,000 peasants were convicted of "endangering public welfare."

50 In the early fifties, the kulak list had about $60-70,000$ names. 
As a result of political and economic pressures on peasants, land flight (leaving behind the recently acquired holdings) became a widespread phenomenon in the early 1950 s, with some 300,000 people leaving agriculture temporarily or permanently. In 1957, the number of individual farming families where one or more family members were kétlaki "dual residents" - commuting between work in industry and home because of attachment to the land - was estimated to be 650,000 . They constituted $35 \%$ of all individual farmers and $40 \%$ of the total workers' class. The politicians labeled these new industrial workers of peasant origins as the least valuable, least educated, and (from an ideological point of view) most untrustworthy elements of the labor force, incapable of shedding their out-dated, conservative landholder mentality (VARGA 2012:40-41).

The ruling ideology labeled peasants (more than half of the population) as a reactionary vestige of feudalist clericalism and capitalism, a class targeted for elimination. Communist demagogy sharpened conflicts between towns and villages. Newspapers, schoolbooks, products of the new socialist movie industry, the ten-minute newsreels (shown before movie screenings) aimed to illustrate the bluntness and shrewdness of those who clung to outdated traditions, the "haunting shadows of the past," in juxtapposition to the enlightened modern socialist heroes and heroines of the new age. ${ }^{51}$ On the other hand, a Janus-faced rhetoric began to exploit a falsified vision of "folk culture" in socialist realist "art." Gigantic frescoes and monumental statues in public spaces and staged choreographies of state folk ensembles all advocated the myth of friendship between "happy" peasants and workers. (Figure 11)

However, the demagogic pseudo-appreciation of folk culture did not prevent the peasantry from being socially shunned and deprived of its human dignity. Villagers recall the way they were humiliated for their traditional dress in their everyday encounters with city dwellers on streets, in shops, or on public transportation in the cities in the 1950s. This breach within the peasantry, its awareness of its devaluation, the feeling of "it's not good being a peasant" was expressed in shocking confessions everywhere. "We were the lowest of the low in the city." "We were pushed around in the city, they didn't even speak to us." "They would trip us, burn us with cigarette butts." "I'm poor, this outfit is not kulak, that's what I told them when I was called a kulak in the city." "Because of our wide skirts, they thought we were peasants." "Because peasants were put down like this, everyone wanted to become an urbanite instead [i.e., wear city clothes]. This was the attitude." my informants said. ${ }^{52}$ In some places, the grievances of the 1950 s flared up even after three decades, such as in the prosperous Apátfalva on the Southern Great Plain. ${ }^{53}$ Elsewhere, for example in the poor peasant Palóc villages near the mining and industrial centers of Nógrád, this period did not bring up such dramatic grievances.

The political and ideological stress and the burden of devaluation and deprivation of self-pride urged peasant communities to cast off their traditional dress, which was

51 Young boys and girls of agrarian proletarian background who were educated in newly established People's Colleges with the aim of transforming them into loyal cadres of the regime were in fact turned against their own past.

52 LosonCZI 1977:215-222. The chapter titled "The Peasant-Worker and Worker-Peasant Contrast" provides examples of traditional stereotypes of mutual recriminations.

53 On the persecutions of the 1950s in Apátfalva, HaLísz 1975:29-31. The grievances of the 1950s were also mentioned by my informants in Apátfalva a lot. 
construed by this hostile environment as a badge of "kulakness." Communities responded differently, and this was partly related to the intensity of the persecution: some "broke" and the 1950s became an era of mass folk dress abandonment; others "persevered" and only the 1960s brought a real turn from them. (Figure 13) The third reaction was a "strategy of hiding." Those who chose this packed away their colorful silk and velvet attires and put on a "gray," neutral, cheap dress, which still consisted of a skirt, blouse, apron, and headscarves. This dress was not provoking, but still gave them the sensorymotor feeling of traditional costume.

An example of the latter is Regöly in the Kapos river valley, where until the 1950s essentially everyone wore the costumes of the prosperous peasant-bourgeoisie. ${ }^{54}$ The last surviving festive clothes are from the 1940s, they were no longer made in the 50s, "kulaks would not dare renew or flaunt their clothes." Encouragement to abandon traditional folk dress came from the top through teachers, disseminating it through the children. Some of the women of Regöly took off their rich velvet and brocade peasant attire, but instead of an urban dress, they adopted a "gray," nondescript dress that ultimately reflected peasant taste, even if it had little to do with their heritage. "We put this on when others took off their peasant costume," the women said. In that neutral dress, they hid in dullness, but ultimately stuck to a peasant ideal. They could remain peasants in it, and it still gave them the familiar feeling of the intimacy of "our costume." 55 (Figure 14-16)

${ }_{54}$ Regöly was a market town until 1872, then a large municipality, and since 1900 a municipality. The construction of railways and roads bypassed it, it was not involved in the production of goods. It is a community with a special self-awareness due to its historical past and horse-keeping traditions. By the 1980s, it was a village with a rapidly declining population due to its one-child tradition, with no retaining force.

55 'Our costume' is a term often used by the locals. A Morva-Slovakian paralell by Petr Bogatyrev written in 1937: "The folk sometimes designate this general function with the term 'our costume' (naš kroj) - which indicates not only the regionalistic function, but some kind of special function... Mother tongue and 'our costume' derive their priority from the fact that they are closest to us of all languages and costumes. The general function is most akin to the regionalistic function, but there is a fundamental difference between the two..." While based on the regionalistic function we compare a costume to that of other regions, in the case of 'our costume' we are not primarily talking about such a juxtaposition, but rather that it is this costume of all kinds of clothing that is the closest to the wearer. This characterization may also apply to clothing that has no regional or national function at all. "In analyzing the concept of 'our costume', we observe that there is a strong emotional element expressed in it" (BOGATYREV 1971:96). 


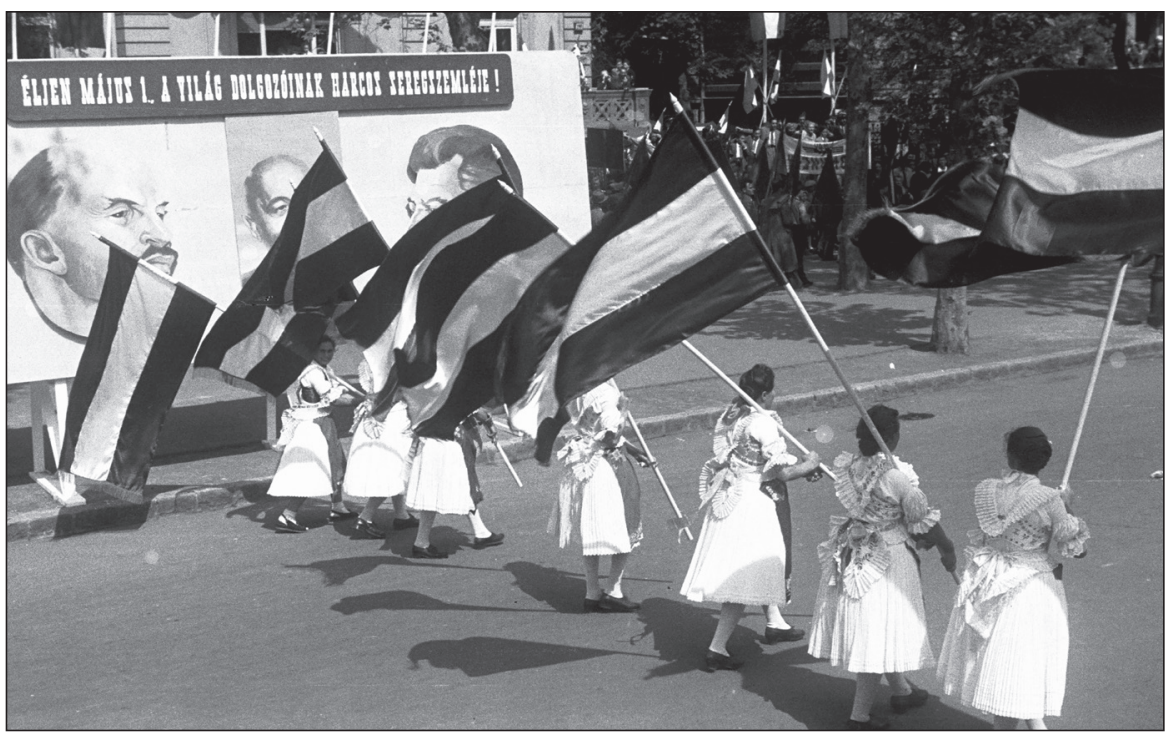

Figure 11. May Day parade in Budapest on Népköztársaság avenue in 1949. In front of the images of Lenin, Mátyás Rákosi, and Stalin, peasant women from the countryside, dressed in their folk costumes, march with national flags, demonstrating the worker-peasant friendship. The sign reads: "Long live May 1. The parade of the workers of the world!" (Photo: Fortepan 142710, donor: Chuckyeager tumblr, downloaded Aug 10, 2020, http://fortepan.hu/_photo/ download/fortepan_142710.jpg?rand=1597075673)

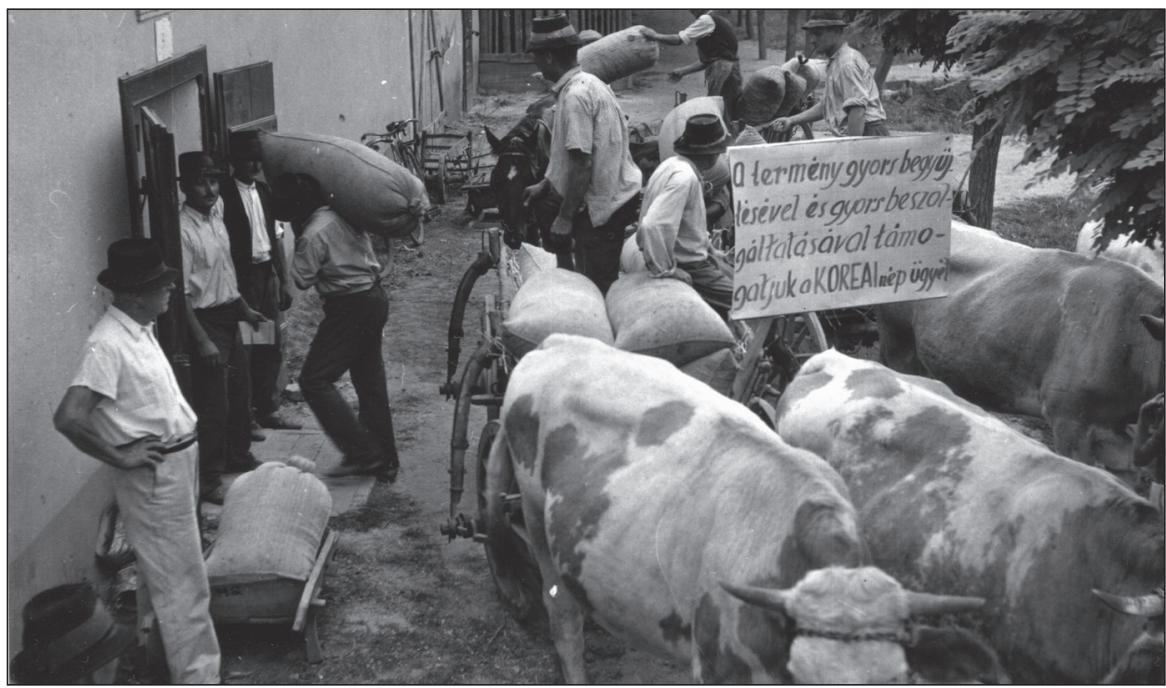

Figure 12. Requisition of crops, 1950. The banner bears the following slogan: "Supporting the cause of the KOREAN people by the rapid collection and delivery of crops." (Photo: Fortepan 128495, donor: Sándor Bauer, downloaded Aug 10, 2020, http://fortepan.hu/_photo/download/ fortepan_128495.jpg?rand=1597077024) 


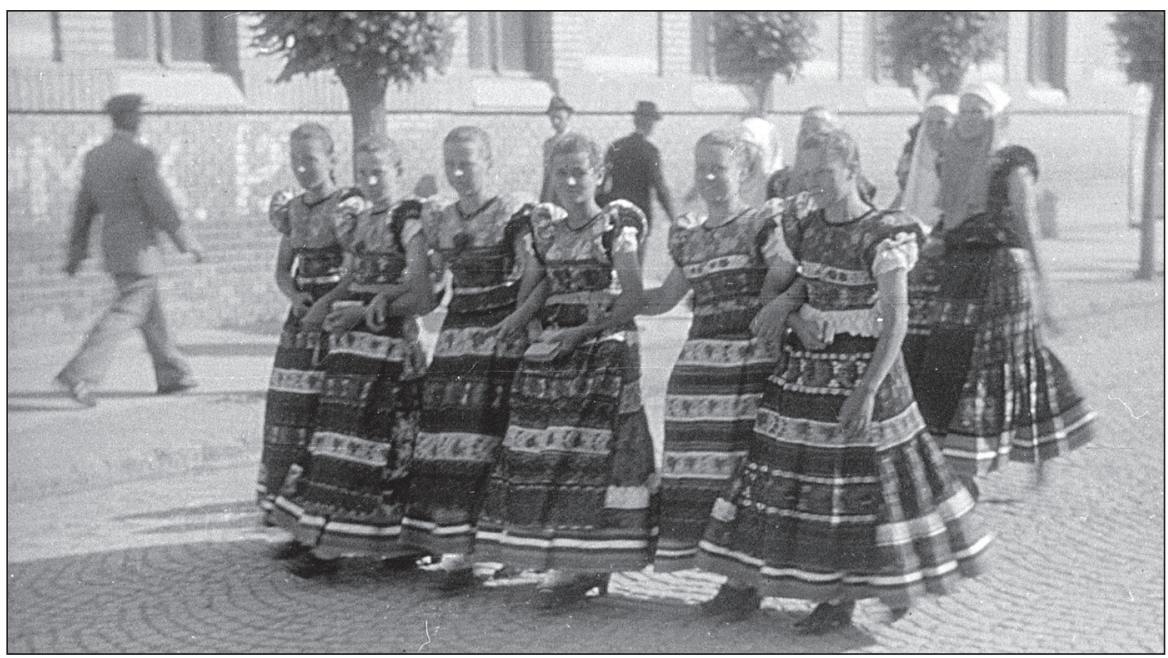

Figure 13. Karulás (linking arms), girls promenading on Sunday on the main street of Mezökövesd (Borsod county), May 1948. The picture was taken around the time of the communist takeover in Hungary. On the wall of the building, the white letters MKP reads Hungarian Communist Party. According to the description of the photo: "On Sundays and public holidays, the girls of Mezökövesd link arms in groups of 6-8-10-12 and walk along the main street in countless such lineups. This picture was taken before the morning mass, but the real 'karulás' usually takes place in the afternoon, after litany service. Only girls dressed in costume participate. The few who had already cast off their old clothes and put on new ones would not take part in the 'karulás'." (Photo by László K. Kovács Photo Collection of Museum of Ethnography, Budapest, inventory number: NM F 95225)

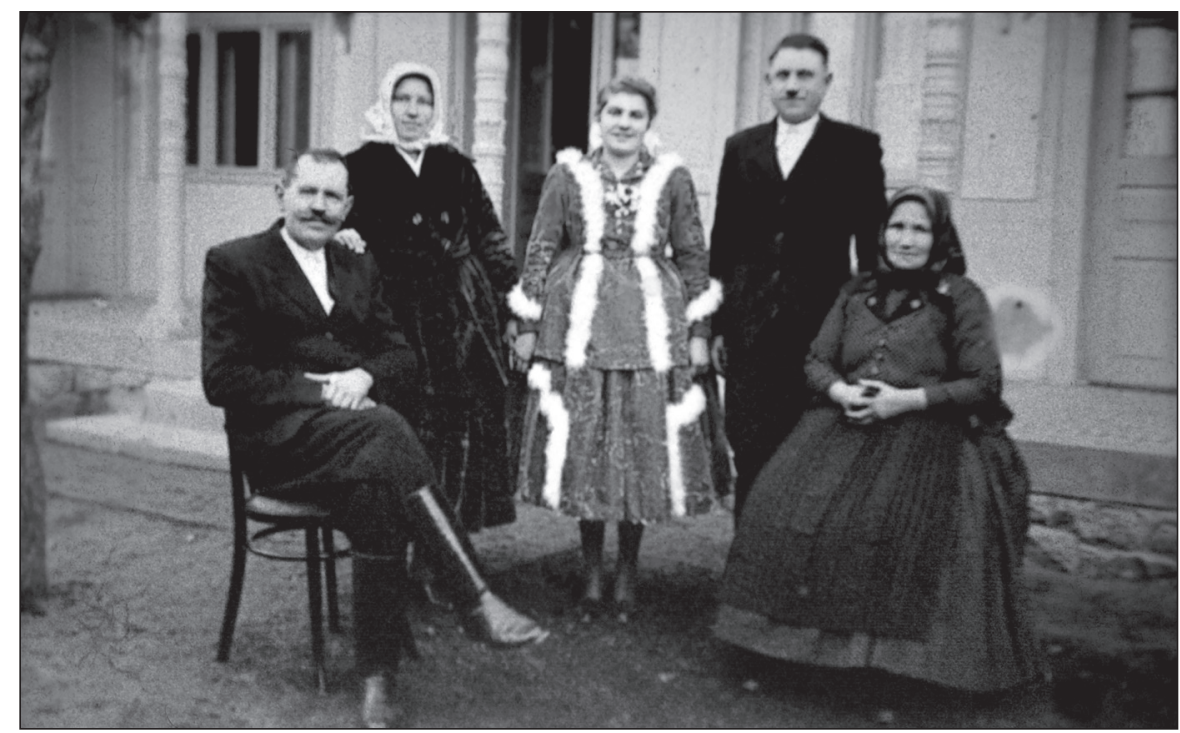

Figure 14. Family of a big farmer in 1946 in Szakály (Tolna County) (Photo privately owned) 


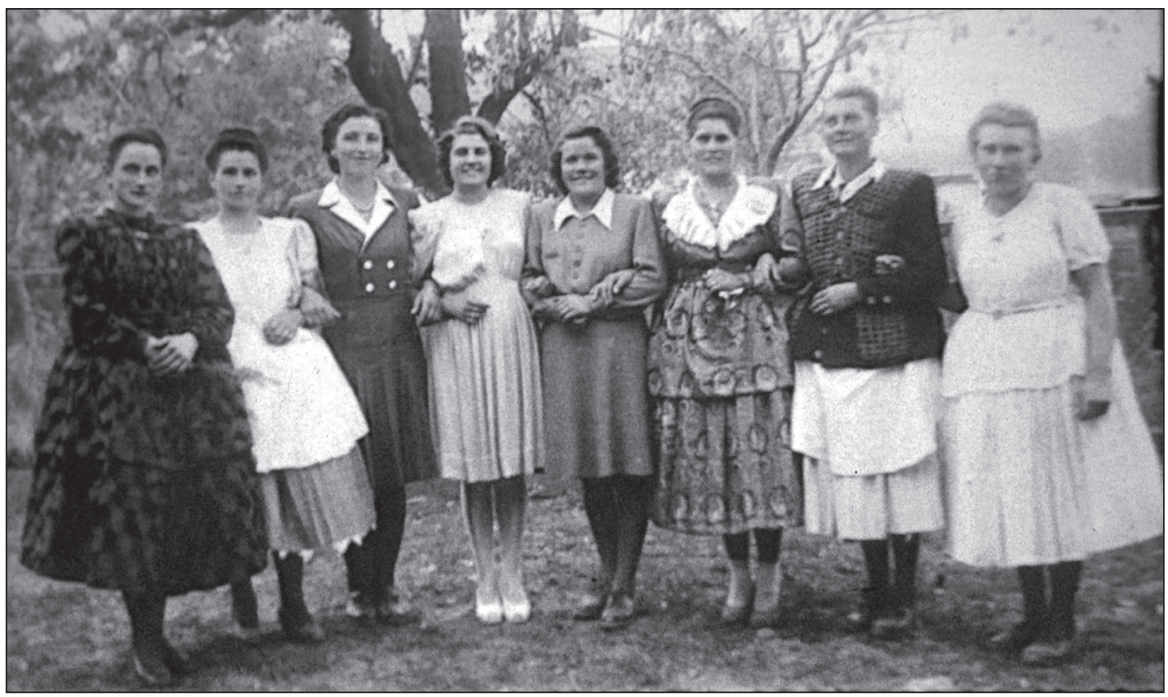

Figure 15. The young woman wearing folk costume in Figure 14, standing in the middle in a light-colored urban dress among her girlfriends in 1946 in Szakály (Tolna County). The picture is a good illustration of the diversity and simultaneity of ways of dressing during the transitional period of costume abandonment. Similarly to the example from Átány described by Edit Fél and Tamás Hofer, in the case of more embourgeoised costumes, after a period of dressing trendy in her youth, this woman wore a costume until her old age. (Photo privately owned)

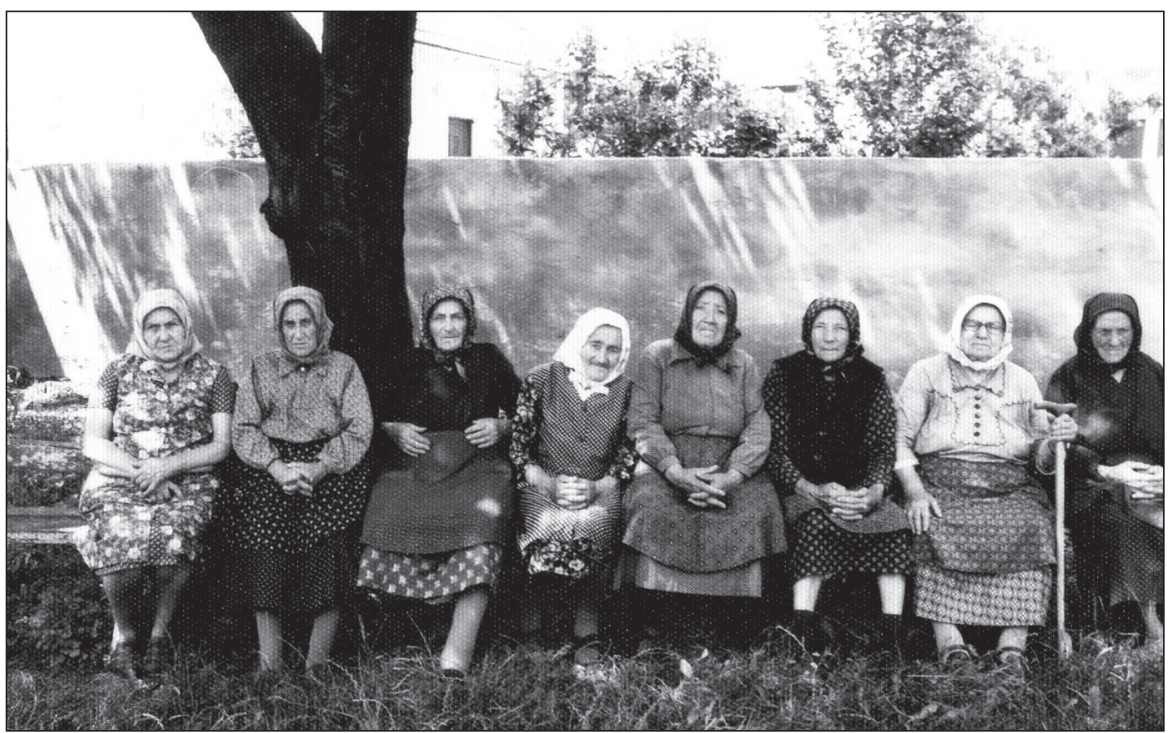

Figure 16. Residents of the nursing home in Regöly, a settlement adjacent to Szakály and part of the same costume group, in 1987 (Tolna county). Variations of their elderly wear (skirt, blouse, apron, headscarf) can be well observed on the women. However, even those "un-costumed" women in their otthonka (housecoat) wear headscarves. (Photo: Ágnes Fülemile) 


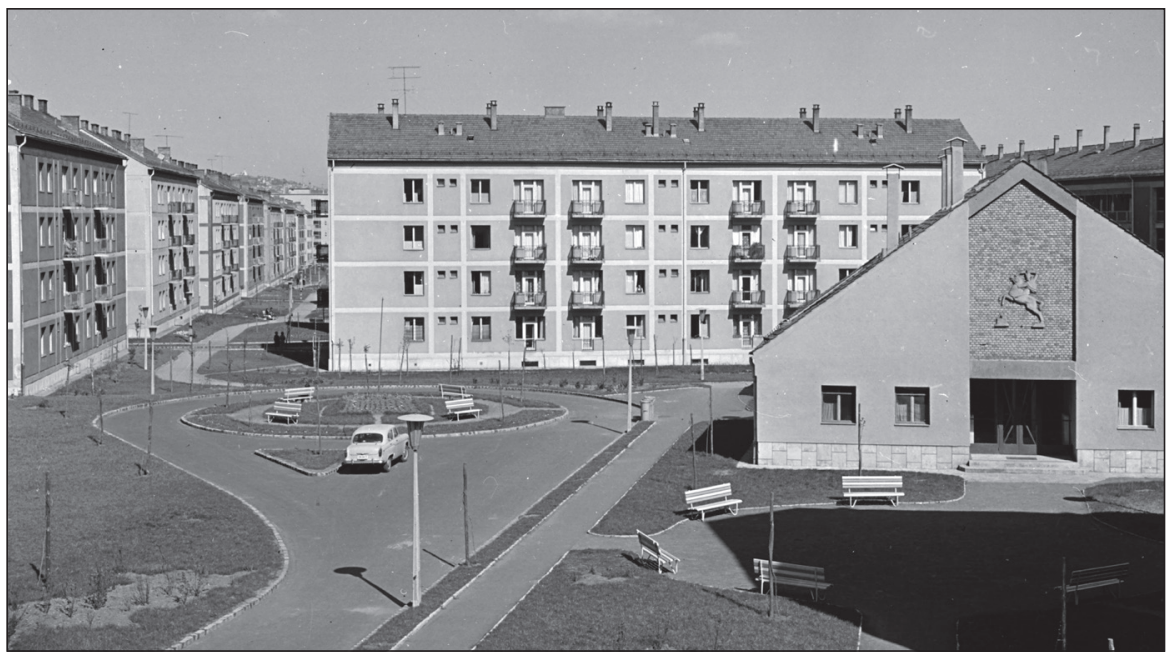

Figure 17. Newly built housing estate in Uránváros (Uranium city), the working-class district of county seat, Pécs (Baranya county); to the right is the kindergarten building, and the car is a Soviet-made Moskvitch. 1960. (Photo: Fortepan 29179, donor: Lechner Nonprofit Kft. Documentation Center / photo by VÁTI, downloaded Aug 10, 2020, http://fortepan.hu/_photo/ download/fortepan_29179.jpg?rand=1597079023)

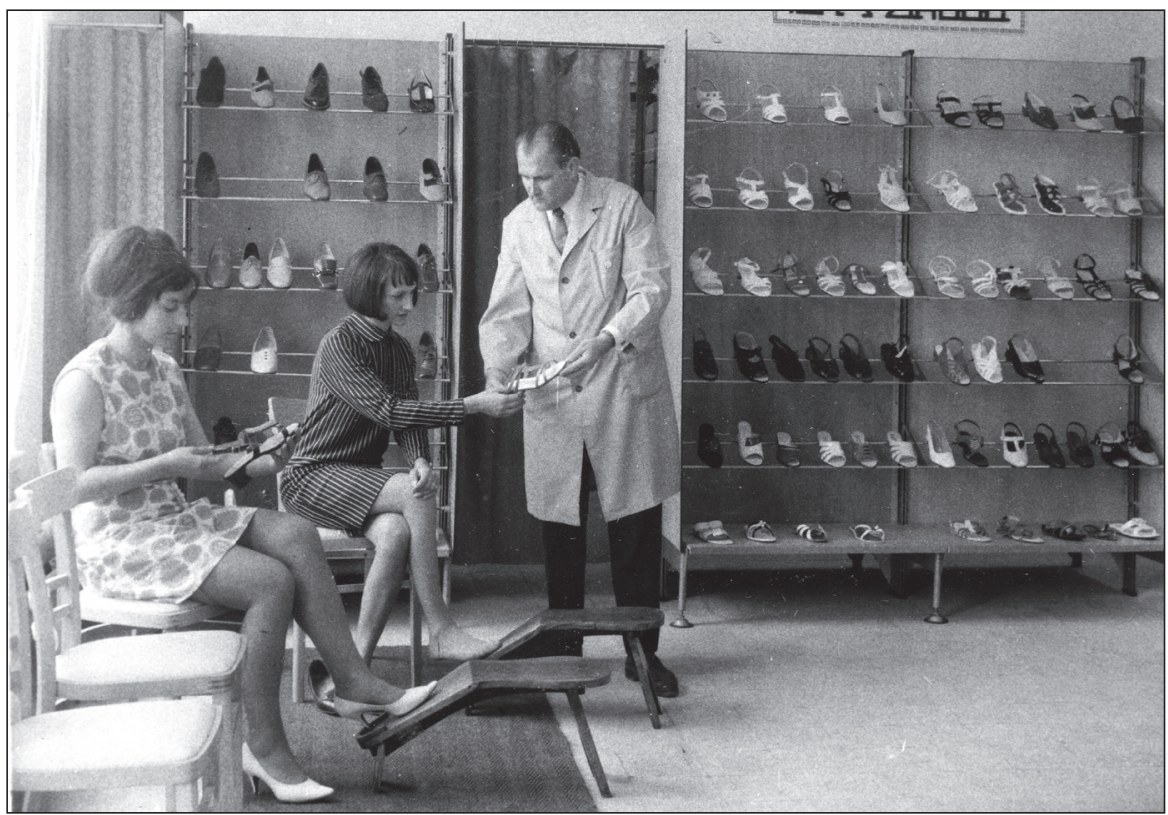

Figure 18. Marketing photo from 1967. Shoppers in minidresses in a shoe store, on the shelves products of the light industry of domestic and allied socialist countries. (Photo: Fortepan: 69896. downloaded Aug 10, 2020, http://fortepan.hu/_photo/download/fortepan_69896. jpg?rand=1597074118) 


\section{Period: 1960s}

The 1960s were the last significant era of the abandonment of traditional wear. For those few local peasant communities that continued to stick to their traditional outlook and customs, the decisive momentum to assimilate was triggered by the period of the third wave of collectivization in 1958-61, which was consistently carried out after the crushed anti-soviet revolution of 1956. The wide-scale collectivization was essentially the "collective punishment" of the peasantry. ${ }^{56}$ Practically, it targeted for elimination and termination the autonomy of peasant existence. The land ${ }^{57}$ (along with the expropriated animals and tools), which was the basis of subsistence of the family household around which values and institutions were organized, was pulled out from under the feet of the peasantry. As a result of collectivization, individual farming almost ceased to exist. (The number of about 1.6 million private farmers decreased to less than 100,000 by the mid1960 s. $)^{58}$ The typical strategy was that the woman or an older family member joined the cooperative, ${ }^{59}$ while the more vigorous men and young people commuted daily, became "dual residents" or moved to the cities.

Following forced collectivization, the hitherto traditional culture of the villages began to dissolve with extraordinary speed. The profound changes could be listed at length, from the overturning of the system of division of labor, norms and hierarchy of prestige to the transformation of village architecture with the so-called cube houses replacing the old long peasant houses everywhere. In the 1960s, not only was it desirable for the rural populations to abandon the appearances of being peasant but there was also a large-scale abandonment of the village and peasant world as well, with all the consequences of mobilization. ${ }^{60}$

An avalanche of rapid changes ensued. Between 1948 and 1965, two thirds of society was socially mass mobilized. In fact, this was a long-awaited and much-needed mobilization process after the frozen, hierarchical, semi-feudal social system of the preWorld War II period. It is also true that for many poor people, the 1960s was the first period in their lives during which there was adequate food to alleviate their hunger. But the social changes were too fast-paced, too dynamic, and, above all, engineered from above at the initiative of an absolute regime that shattered the core of real democratization. The high rate of intra- and inter-generational mobility had all the negative side effects of forced rapid mobilization: suicides, alcoholism, negative birth rate, split families,

56 For the injuries and coercive measures used in this last course of collectivization, see: BALOGH 2009; Ö. KovÁcs 2008, 2009, 2012; Kovács 2013.

57 The defining axis of traditional peasant life was the self-sufficient family farm based on the private ownership of land. Land was therefore not only about social rank but also a guarantee of independence and freedom.

58 For data on the process of collectivization, see VARGa 2001, 2009; VALUCH 2000, 2001, 2003 b.

59 The conservative allegiance to their life experiences of the women who stayed home and worked in the cooperatives is expressed through language like "I would never go, I love the land, I would suffocate in a factory".

60 BALOGH 2009 discusses the fate of the male generation in a Transdanubian village, from the time of collectivization to the time of the study. This was the first generation of men, unable to take over their father's/grandfather's farm in their young adulthood, to whom it became clear that they must break with the hitherto inherited practice of individual farming. 


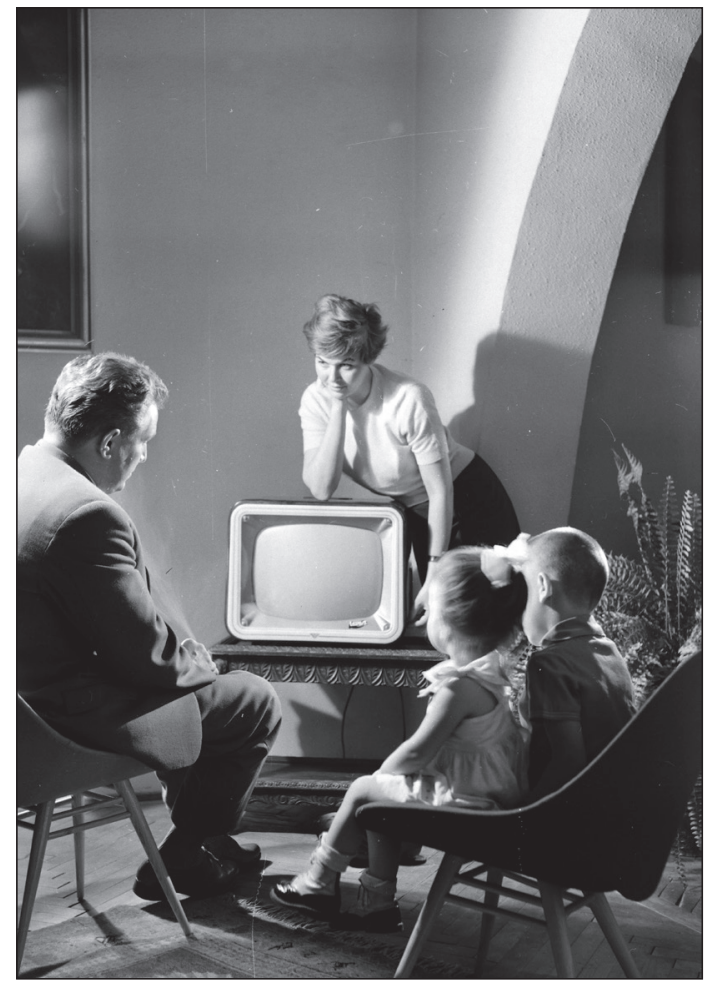

Figure 19. Advertisement for the Tavasz T 4303 television set, 1960 (Made at the Hunting Ammunition Factory, the predecessor of the VIDEOTON factory in Székesfehérvár.) The ideal of a modern family with two children and a pretty mother with a bob. (Photo: Fortepan: Fortepan 19113, donor: Antal Kotnyek, downloaded Aug 10, 2020. http://fortepan.hu/_photo/ download/fortepan_19113.jpg?rand=1597074787) divorces - social trends in which Hungary is regrettably among the forerunners in Europe. ${ }^{61}$

Children of the 1960s were brought up in a general climate that lacked appreciation for and looked down on the countryside. Pejorative stereotypes were part of everyday communication and public discourse about the peasant village. The negative epithets were definitely milder than the "kulak slogans" of the 1950s anti-peasant propaganda, but this tamer image was still sharply sarcastic. School books and children's storybooks showed images and stories in which prosperous peasants appeared in negative connotations while the agrarian proletariat and workers in positive connotations as the ideologically correct segment of society. Teachers and nurses often expressed their dislike of "old-fashioned" everyday customs and practices to families of peasant origin (or families with more than one or two children) in a patronizing manner. School children willingly bullied each other with mockery that represented the public thinking of the time. The hierarchy between cities and villages, as well as the overexaggerated superiority of "water-head" Budapest, often led to inferiority complexes. ${ }^{62}$

At the same time, consolidation and a considerably better standard of living have also made the urban model attractive, which became more and more appealing to the young generations of the rural countryside. From around 1963-64, a more pragmatic, milder form of economic planning was introduced. Instead of exclusive focus on heavy industry, light industry was being developed as well. Socialist consumerism evolved,

${ }_{61}$ On the social mobility of the period and its negative consequences from a contemporary sociological point of view, see ANDORKA 1979, 1982; VÁGVÖLGYI 1982. The changes imposed by the "socialist reorganization of agriculture" also caused serious psychological injuries. From the early 1960s, the phenomenon has been called "cooperative-neurosis" and led to psychiatric examinations. JuHÁsz 1964, 1965, 1970.

62 The uneven distribution of administrative, economic, cultural, and educational institutions headed by the all-encompassing principle of centralization remained a real structural developmental problem in the entire country during socialism. 
and a network of shops and warehouses was established. (Figure 18) The construction of large modern housing estates in the new socialist urban quarters was a dynamic project, and obtaining such an apartment (for reliable workers and comrades) entailed prestige and a rise in living standards. (Figure 17) The advertisement of modern furniture and household electronics complementing the apartments promoted new female ideals. The increase in the number of active workers included one million women entering the workforce, which challenged the traditional concept of family and household structure. An improved network of nurseries, schools, and health services was needed. The idea of leisure was born, with a network of vacation houses for workers. Work collectives and school classes began to go on excursions or visit theater performances. The development of transport and education, as well as mass communication and the media helped to convey the new models (STEFÁNy 1986). Magazines and the start of television broadcasting (in 1957, although owning a television set only became widespread in the mid-1960s) provided strong role models through speakers and actresses. (Figure 19)

Furthermore the collectivization of the sixties provided a loophole, which was the distribution of backyard holdings of limited size to the members of cooperatives. The importance of household gardening grew after 1968, when a reform policy called New Economic Mechanism introduced a series of liberalizations, including limited market mechanisms. As a result of the beneficial effect of the NEM, the nature of farming on the backyard holdings has changed from self-sufficient to commodity-producing. Crop yields were measurable at the level of the national economy. ${ }^{63}$

Incidentally, a significant proportion of aspiring small farmers with market incomes came from formerly rich and middle peasant families. In the prosperous socialist village, which even the city-dwellers envied, pluriactivity and overtime provided the basis for the part-time second economy (or even semi-legal third), with women playing a significant role. ${ }^{64}$

Examining the small farmers of the 1960s and 1970s, sociologists began to write about "depeasantization," the disappearance of the peasantry in its historical sense. ${ }^{65}$ The dual-resident semi-laborer/semi-peasant families who preserved certain elements of their former way of life and culture lived essentially in a kind of transitional state, in the torrent of an irreversible, "self-eradicating" process. ${ }^{66}$ The Hungarian rural world

${ }_{63}$ In several intensive sectors (pigs, grapes, fruits, and vegetables), the household economies were generating $50-60 \%$ of the production, and even $80-90 \%$ in the case of early vegetables grown in poly-tunnels, as well as some small animals (MoLNÁR 1996:631-643).

${ }^{64}$ See, Harcsa 1991; Huseby-Darvas 2000.

${ }_{65}$ Several articles have been written on the "depeasantization" phenomena (the social, economic, and cultural consequences of collectivization), including the debate in the journal Századvég; see Valuch 2003a; Kovích 2003; LaKi 2003; HaRCSA 2003.)

66 Rural sociologist István Márkus considered the term "peasantry" irrelevant in their case. Perhaps partly inspired by Henri Mendras (MenDRAs 1970), he uses the term "post-peasantry" and in terms of 'longue durée' (long-term processes), he considers the 1960s and 70s to be the end of an era and the beginning of a new one. Of the radical changes, he writes: "In the sixties and seventies, we are dealing with an agricultural society that had been substantially restratified, first by land policies, then by the eradication of a wide stratum of rich and middle peasants, and finally by collectivization carried out in several waves. These are villages and farmsteads from which hundreds of thousands 
of the 70s and 80 s, with its "post-peasant" ${ }^{97}$ villages with prosperous cooperatives also attracted the attention of social sciences. (Varsány, Tázlár, Cserépfalu, Sárosd, Táp were research sites of British, American and Hungarian anthropologists and ethnologists. ${ }^{68}$ )

Altogether by the 1960s, a change in lifestyle, social mobility, and female employment were clearly the triggers of the abandonment of folk dress as well. The above-mentioned forces of modernization and urbanization sped up the process of the disintegration of peasant culture, which became unstoppable at this point.

The same forces that are behind the disintegration of traditional endogamous marriage circles, which defined mate selection for hundreds of years, are also behind the disintegration of "peasant dress." The network of regional marriage circles ${ }^{69}$ among people of the same religion, ethnicity, and social standing usually included a few settlements in the closer or more distant vicinity with whom mate selection was socially preferred or accepted. The long-time kin connections created "islands" of people with similar anthropological and cultural features. People sharing the same religion, festive and ritual occasions, identity, and culture developed similar costume expressions as well. In other words, these marriage circles were the basis for and coincided with the boundaries of the regional costume variations. Young villagers working and studying in the urban-industrial centers in the 1960s who started to secure mates from outside the traditional marriage circles found the divergent cultural expressions increasingly uncomfortable. Often the time of the last wedding in traditional costume coincided with the years around collectivization.

I cite two examples of the watershed role of the 1960s. Zengővárkony and the nearby Reformed Presbyterian villages in Baranya, along with Reformed villages from the Sárköz region in Tolna county, had its last St. Luke Ball, "Maiden's Market" (i.e., "marriage market"), and Harvest Festival in which traditional dress was worn in the early 1960s.

commute to work in the city, to industry, construction, or offices, and where the two generations since 1945 have graduated from at least elementary school, but most even vocational schools. By now, the typical family is a family making a living from several types of work - semi-laborer, semipeasant, sometimes semi-intellectual families. This so-called post-peasantry - which we know is still a broad category - is given the opportunity after 1960 to make money from, among other things, small-scale agricultural production. And the earnings are not insignificant compared to previous peasant earnings or even industrial wages or local teachers' pay of the same timeframe. This is where a new factor comes into play... There was an explosion of ambition. Huge masses of the Hungarian peasantry - including millions of former poor peasants - were given the opportunity in the 1960s-70s, after several false starts, to throw off the shackles of being a peasant. They erected hundreds of thousands of urbanized houses with bathrooms on the sites of the - out-dated or livable, but definitely peasant-style - old houses, which were then furnished according to urban fashions. In their dress, foodways, evening TV viewing, children's clothing, and later car buying and garage building, they sought to catch up to or even surpass their city-dwelling neighbors" (MÁrkUs 1991:200-201).

${ }^{67}$ For Márkus' "post-peasantry" category, sociologist Iván Szelényi uses the term "peasant-worker" in his model called "interrupted embourgeoisement." SzELÉNYI (1983) had an inevitable impact on the historical, sociological, and ethnographic discourses on socialist enterpreneurialism and embourgeoisement (as the "third way").

68 E.g. SÁRKáNy 1983; HanN 1980; Huseby-Darvas' dissertation in 1980; LAMPland 1995; Hollos MADAY 1983, etc. Further details, see SÁRKÁNY 2019.

69 A detailed analysis of the regional network of marriage circles in a particular region (in Kalotaszeg, Transylvania, Romania) and its role in the formation of regional structure and identity, see BALOGH - FÜLEMILE 2012. 
This fact is interesting not only in terms of costume. The "marriage market" held during the weekend of the St. Luke's Day fair in October, after main agricultural work has ended, provided a traditional occasion for meeting and courting for the young people of the Sárköz ethnographic group, which ensured endogamous marriages between geographically distant sporadic Reformed Presbyterian villages in the dominantly Catholic Southern Transdanubia, thus preserving the cultural homogeneity of the ethnographic group. The discontinuation of endogamous marriages began a process that led to intermixing, the loss of a specific culture, and ultimately the complete dissolution of the regional ethnocultural group. Several informants brought it up that with the first "mixed marriages" in the early 1960s, when one of the spouses came from outside the traditional marriage circle, reconciling the different wedding customs with their own was problematic. The same was observed in Galgaguta (Nógrád county), for example, where endogamous marriages between neighboring Slovak villages ceased also around this time.

In most of the villages studied, where the abandonment of traditional dress had started earlier, it came to a close by the 1960s. Elsewhere, the hitherto sporadic abandonment became widespread at that time. After the 1960 s, only a certain percentage of the middle and older generations continued wearing traditional dress, and in most cases they had done so until their deaths. In essence, the generational chain of the transmission of the clothing culture has been broken, the traditional process of handover has ceased, and the traditions preserved by only a minority group have necessarily changed. In the last communities still wearing peasant dress, a generation gap started to develop in this period. After this split, the subsequent younger generations dressed the urban way.

\section{THE COURSE AND LOGIC OF COSTUME ABANDONMENT}

At the beginning of the abandonment of traditional clothing, several age groups can act as initiators. Girls' abandonment is more typical where there are economic reasons behind it. The change of dress took place even before the dowry was assembled, since for whomever the family was able to assemble a dowry - a wardrobe for a lifetime continued wearing those clothes for the most part until the rest of her life. ${ }^{70}$ In such places, the initiators were poorer families or families with many daughters. (The eldest daughters, who inherited clothes from female relatives, generally continued wearing

70 The dowry consisted of the costumes of the bride for her entire life cycle, from adulthood to death, along with the furniture to store the dowry in and the bridal bed and bedclothes; household textiles for every functional purpose and representative occasion; and a parcel of hemp field (inherited through the female line) for providing for the future family's basic textile needs. According to the traditional system of inheritance customs, while all sons shared the inheritance of the parental real estate equally, daughters received their share in the form of a dowry. Female land inheritance was gradually introduced by a modern legal system only in the late $19^{\text {th }}$ century, but the custom of the bridal dowry was preserved well into the second half of the $20^{\text {th }}$ century.

Since the dowry provided the bride's wardrobe from head to toe for every occasion (new items were rarely purchased after the wedding, except for some functional everyday pieces), the "fashion" at the time of the wedding was thereby conserved by consecutive generations of contemporaries. The quantity and quality of articles in the dowry (albeit with variations according to period, region, economic and social background) aligned with the local community's ideal of clothing at the time. 
traditional costume, while the younger ones were already forced into urban clothes. Their emotional attachment to the costume usually remains strong for the rest of their lives.) Since the dress change was a stopgap measure here, not triggered by upward social mobility, the process of abandonment was slow, protracted, as the new style of dressing had no prestige value.

Young women first started abandoning local costume in places where the abandonment was not necessitated by financial considerations and often was motivated by social mobility (hypergamy). Young women had relatively more freedom in the village society, thus had more independence in their clothing choices. The husband rarely got involved in the details of clothing, but he raised his voice on the issue of abandonment of traditional clothing. While with girls it is the social status of the parental home that is decisive, with married women it is the social rank of the husband's family that is decisive. The husband's social status and the nature of his work usually determined the way the family dressed. (This is not true for hypogamy.)

It is worth noting here that since the abandonment of traditional dress is typical for young women, the date of the last costumed wedding may be a pointer for the researcher. Changes in the traditional care and dressing of newborns and babies follows the dress change of young women within a few years but may also be delayed. After all, the adoption of the urban model of dressing does not mean an immediate change in the traditional knowledge of childcare. ${ }^{71}$

The readiness of the middle peasantry to preserve tradition is clear. The initiators of change in dress style were typically not the middle peasants but the daughters (or "some of the daughters") of the rich peasant families. In other cases, it was the more mobile daughters of poor peasant families working as seasonal farmhands or maidservants who pioneered the changes.

Thus peasants thought in terms of creating and composing ensembles of articles, conservatively maintaining the system over a long period of time - at least for the lifetime of their own generation and they often disallowed (or were slow to accept) changes.

The compilation of the dowry was a long process that lasted many years. During the childhood of her daughter, the mother first produced the less valuable everyday household textiles and more valuable pieces were produced only after the girl reached a certain age. Girls began to learn textile techniques at the age of five or six and by the time of their wedding, they would have mastered the finest techniques they needed to exhibit by making some special pieces. As part of the wedding ceremonies, the dowry was ceremonially transported from the bride's house to the bridegroom's, displayed on a carriage. The community "inspected" it, commenting on the quantity and quality, and also judging the bride's merits based on her embroidery skills.

Among the most valuable pieces of the dowry were the festive garments inherited from the mother, grandmothers, aunts, and godmothers. Through these articles, an entire female lineage, family history, and genealogy were preserved. Retelling the personal stories behind these articles to younger family members was a means of maintaining memories. (An exemplary analysis of the above from Méra, [Kalotaszeg region, Transylvania, Romania], see TöTszeGi 2009:99-110, chapter: „A viseletdarabok életútja. Családi emlékezet a viseletdarabok tükrében” [The life course of costumes. Family memory in the light of costumes.])

${ }^{71}$ Not from Hungary, but very typical example is from the Moldavian Klézse (Cleja) in Romania - where I attended a Catholic baptism two months before the outbreak of the Romanian Revolution in the autumn of 1989 - where women in their 20s and 30s (i.e., of childbearing age) had abandoned traditional dress in their teens, or had never worn costume at all, and folk costumes were reserved for major holidays only. Yet baby care and dressing remained uniformly traditional in all families, 
The social prestige and significance of the new dress code chosen after the abandonment of traditional dress should always be assessed in the light of specific local development. Wearing city clothes can be either a sign of prosperity or impoverishment, depending on what social group initiates the change, who chooses it as a model to follow. ${ }^{72}$

Some situations required individual initiative and a stronger desire for involvement. It should also be mentioned here that the initiators of the abandonment needed the same amount of initiative and individual courage and were just as much in a minority position as those towards the end of the process who were the last to stay in costume.

The flip side of the phenomenon is that in the $1980 \mathrm{~s}$, it was not just the more conservative middle peasants that spearheaded the retention of folk dress but often those from poor peasant and servant families, taking advantage of the late, anachronistic opportunity for self-realization to finally gain acceptance with their peasant look into a social class that they always aspired to. ${ }^{73}$

even for those working in the city. Infants were swaddled up until the age of one, with their hands and feet bound, and beliefs about infancy and bewitching were also very much alive. From the age of one, however, the children were dressed in urban children's clothes available in stores. Here, even a decade or two after the abandonment of traditional clothing, the knowledge of infant care remained traditional. The generational distribution of traditional knowledge is also characterized by the fact that when I was there, the grandparents spoke Csángó-Hungarian and could barely speak Romanian, the middle-aged mixed Romanian with bad Hungarian, and the children mostly used only Romanian.

A regional ethnic group calling themselves Csángó that has lived at the foot of the eastern slope of the Carpathians since the Middle Ages, has been Roman Catholic (unlike the Orthodox majority Romanians surrounding them) and Hungarian-speaking until their linguistic Romanianization in the $20^{\text {th }}$ century. The language of the Csángós, characterized by pre-modern group identity, is an ancient dialect that preserves medieval linguistic features from before the modern Hungarian language reform (with some dialect differences even within the settlement area), and in terms of their intangible folklore, music, beliefs, and folk religiosity, it is one of the most archaic ethnographic groups of Hungarians. (For the language use and identity change of the Moldavian Csángós, see: TÁNCZos 2003; PozSONY 2006; ILYÉs et al. 2008.)

72 Mária Kresz drew attention to the same in 1950 during a lecture, with fresh contemporary eyes. KRESZ, Mária: A népviselet és a parasztság osztályhelyzete [Folk costume and the class position of the peasantry]. 1950. Manuscript, Museum of Ethnography, Ethnological Database: EA 3442.

73 For example, a woman from a poor peasant family in Kazár was forced to wear a cheaper version of the local costume with a blouse, a so-called "Szele" version. (Mátraszele is a village in the KazárVizslás-Mátraszele costume group that saw a different costume development. In contrast to Kazár, which dictated the fashion within the group, it is characterized by a costume of lower prestige, considered poorer.) The woman said of her dress: "It was by necessity that I liked the Szele version better, but my heart always belonged to the Kazár version." In 1960, when her financial situation finally allowed it, she "switched" back to the Kazár costume. "I felt so poor in the old version," she explained the switch.

The same socio-psychological factor is the reason for former servants' clinging, attachment to the land and individual farming even after the turn of 1960s collectivization, as they had a hard time letting go of the few acres received in the post-World War II land reform. In the economic and market conditions of socialism, individual farming was mostly an opportunity for a politically pilloried, anachronistic, struggling self-sufficiency. A typical example is an individual farmer couple of servant origin from Sióagárd; the woman as a writing woman (drawer of embroidery patterns) and the man as a primás (lead violinist) are truly bearers and custodians of the disappearing local peasant culture. At the same time, the disordered state of their farm, and especially the neglected 
The decisions of women facing the dilemma of costume abandonment are influenced not only by their social status or the roles required by their own work ${ }^{74}$ but also by their individual receptivity to identifying with a role. ${ }^{75}$ For example, former so-called "famous girls," who at the time dictated (and modeled) fashion trends and were central figures in the community, having adapted to the changed circumstances, emerged from the 1950s in new roles as female activists, congressional delegates, campaigners, members of heritage "showcases." "76 Involvement may be affected not only by one's actual situation but also by yet unfulfilled desires. (I am referring again to the self-realizing aspirations of former servants and poor peasants.) The folk art revival of the 1970s also saw its share of people who took advantage of the movement and emerged as custodians of folk art: a former wine merchant as a naive painter; the village's first renouncer of folk dress who later sold made-to-order dolls in folk dress, etc.

The first attempts to abandon folk dress were usually made in smaller groups. The most vocal ringleaders would organize the "transition" among their relatives, girlfriends, or schoolmates, and thus several people would come out in public at the same time, which gave them strength. ${ }^{77}$

When only a few choose to abandon traditional clothing, it usually provokes resentment from all generations of the community. As dress change becomes more frequent, public rejection also weakens. As abandonment becomes more widespread, the process itself accelerates. The fear of falling behind the majority's position quickly puts an end to change.

Adoption of the position of the majority is often not admitted, rather disguised with pseudo-ideologies. Justification is often inconsistent, whether about abandonment or retention. All changes are ideologized. Rationalizing abandonment was easy as selfjustification. What they hadn't found uncomfortable before suddenly started to become

interior of their dwelling, clearly shows that they lack a kind of established order of things seen with middle peasants, which shows that they still lack a certain knowledge, unable to completely shed the mentality and experiences carried over from their poor peasant past.

In her study on Varsány, Katalin Jávor writes that many of the former servants belong "to the peasant type in terms of their desires." "The previously poorer strata want to establish the prestige values of a former peasant life that had been unattainable for them from their current income from non-agricultural work. (Rich folk costume, large wedding, own vineyard.)" (JÁvor 1978:333).

${ }^{74}$ I am not just thinking of women's jobs available to the poor peasantry at the beginning of the century and between the two world wars, but also of the "employment" of women from the 1960s by the socialist state in general, especially after the establishment of cooperatives, the placement of some portion of rural women in industrial and service jobs, and the education of young people.

75 For example, a woman (in her 60s at the time of the study) from Bag continued wearing folk dress throughout her 16 years working in the cooperative. When she became a cleaning lady at the Railway Directorate in Budapest in the mid-70s, she switched her dress to urban. Photos taken at her old and new workplaces among colleagues clearly indicate how perfectly she identified with the roles, how well she followed the models in all external features and behaviors.

76 For example, in 1951, the vice-president of the town council in Acsa was the same writing woman who introduced colored embroidery in the village in 1948. (Report on the Ethnographic Study Tour of Textile Factory Designers. 1951. III. Kispest Textile Factory - Acsa, manuscript, Museum of Ethnography, Ethnological Database: NM EA 2492.)

77 We need to stress though, that even before group abandonment began, there were sporadic examples of individual abandonment of folk dress. Marrying outside the village or marrying up, as well as working outside the village, especially in the city, provided an opportunity for this. 
such: "it's heavy," "it's unhealthy," "I can't get the fabric for it," and a list of other excuses. A woman from Bag, for example, in justifying her abandonment in 1978, blamed her gallbladder surgery from 1965 - obviously not admitting the real reason. Others, also in Bag, justified the abandonment with the cheapness of urban clothing. One woman, on the other hand, put it this way: "It wasn't actually cheaper, and a lot of old clothes just went to waste. It was like an avalanche, it started and took everyone with it." In Sióagárd, a "slogan" was even made for the return to traditional dress in the 1970s-80s: "new fashion wears out, the Agárdi outwears." (Of course, there is some veracity in these arguments. But typically these aspects did not exist before or were not primary to them.)

It often seems that one of the reasons for abandoning traditional dress can be found in the difficulties in obtaining the materials needed to make it - at least this was often reported by the informants as the most important factor. In fact, the difficulty of sourcing was only a secondary factor. ${ }^{78}$ Where the process of abandonment had already begun and was in its final stages, this could have been a real reason. But where costume was still so much alive that it was able to accommodate and adapt new materials, the lack of material was never the direct trigger for abandonment.

In the past, in the late $19^{\text {th }}$ and early $20^{\text {th }}$ centuries, factory-made materials were seamlessly incorporated into folk costumes. Almost every decade had its own factorymade materials fashionable among the peasantry and found all over the country, used and adapted according to local wear. Moreover, in some villages, such as in Zsámbok, near Gödöllö, even the fashionable synthetic materials of the 1960s and 1970s had been successfully incorporated into the costumes that were still capable of renewal, just like other factory-made materials that were now accepted as traditional. ${ }^{79}$

I do not consider the incorporation of new elements into the costume system to be abandonment. In some of the villages experiencing the late flourishing of folk costume, blouses, shoes, knitted sweaters and cardigans, new materials, colors, and shapes have been incorporated into peasant clothing as organically as, for example, previously the

$\overline{78}$ Lack of materials was a real problem in villages that were directly on the front line during World War II and the material destruction was great, such as in the Galga river valley. But here, too, this was a problem rather for certain individuals and not for the community as a whole.

79 Incidentally, the intellectual contemporaries were just as repulsed and alarmed by these materials (e.g., silk, brocade silk, velvet) at the time as they were at the sight of a jersey blouse or imitation leather bag in the 1980s. An interesting group of sources are the mini-monographs made in the 1930s, preserved in the Ethnological Database of the Museum of Ethnography, written by local cantor-teachers and pastors at the commission of the Royal Hungarian Inspectorate on the folklife of their own villages. The quality of the papers is variable, but what they have in common is a nostalgic intellectual approach: a benevolent, helpful realism on the one hand, and on the other hand, an almost cartoonish search for a past, cast in a naive, wistful, flowery language. Every one of the authors waxes nostalgic about the old linen clothes, boots, and bodices, which they consider to be typically Hungarian, and are averse to the new materials and garments: "Our people were happy in their own simplicity. Today they have been corrupted by silk rags...". "Both in levente performances and in church, we condemn the imitation of foreign fads and encourage our sensible godly people to stay in their original happy, pre-war (i.e., World War I) lives and customs," writes the cantor-teacher of Edelény in 1930 (NM EA 4728). "Girls and young women in bodices and boots have disappeared from our village completely, instead we have girls masquerading in crepe de Chine, sweaters, and silk stockings in front of the church." "Everything has become new, foreign" - writes the teacher of Maconka in 1932 (NM EA 4698). 
aristocratic mente or bourgeois outer garments had been. This is one of the reasons why I do not agree with the interpretation of the abandonment of traditional clothing found in the ethnographic literature, which, focusing on the formal aspects of clothing development, describes the process as beginning with shoes and ending with headscarves a few decades later. ${ }^{80}$

Based on the examples of the villages I studied, I consider a different interpretation of abandonment to be correct (at least in the case of newer costumes whose high period was in the late $20^{\text {th }}$ century). I consider it abandonment from the conscious and radical act of an individual consciously deciding to adopt a new style of clothing. In my experience, abandonment is not an inconspicuous series of gradual, slow, small changes in the life of either the individual or the community. There is a conscious role reversal behind the change in the clothing structure. ${ }^{81}$ Women who once wore traditional costume refer to their abandonment of it as a "big decision," a major milestone their lives, a "baptism of fire" whereby a new phase in their lives has begun.

A clear example of this is the tombstone of a woman from Kazár who died young in the 1970s. Her family considered it important to have two photographs on the tombstone: one from the young woman's life in folk costume, one from her life after her abandonment of it. It characterizes the family's value judgment that the front of the tombstone has her image in costume, while her post-abandonment photo is on the back. It is as if they erected a memorial to two different people.

I consider it a separate issue whether the clothing perceived as peasant by their wearers before the consciously undertaken radical act of abandonment had any bourgeois features (shoes, blouse, etc.), and, conversely, whether the urban attire chosen upon abandonment had any features reflecting a provincial taste (headscarf, etc.).

\section{Niche market for cast-off traditional garments}

As for the difficulties of the procurement of supplies, in addition to the above-mentioned possibility of adaptation, there is another remarkable phenomenon which indicates that a lack of supplies cannot be accepted as a true reason for abandonment (only as a motive). As long it is important to a community to procure the materials needed for the making of costumes, they will find all "hidden" ways of sourcing. An accompanying phenomenon of the abandonment of traditional clothing is the emergence of a niche market for cast-off traditional garments. Pieces of the wardrobe of those who changed dress were not wasted.

80 E.g. Alice Gáborján interprets the sometimes decades-long process of the embourgeoisement of clothing as the abandonment of traditional dress: the dress change begins with the footwear, continues on the upper body, followed by the skirts and trousers worn on the lower body, and finally the hairstyle and headdress. She considers the "complete victory of factory-made materials," a curved cut line replacing straight cut lines, and the use of tinted and muted colors instead of pure, bright colors to be the criteria for abandonment (GÁBORJÁN 1976:9-10). However, Edit Fél considers the latter features, and even the use of shoes, to be characteristic of the "newer costumes" in their anachronistic late bloom in the $20^{\text {th }}$ century (the costumes of Kalocsa, Vác, the Pest area, and the Galga river valley) (FÉL 1962:26).

81 Bogatyrev 1971:93-94 also describes the process as "A Change in Costume as a change in the whole Structure of Life." 
The truly valuable pieces of clothing were sold. (The less valuable ones were partly converted, partly repurposed for use in the household, some of the articles - footwear, headscarves - continued to be worn.) The ones who chose to cast off their costume were thus able to satisfy the demand for traditional materials of those who retained their costume for some time to come. The ambiguity of the process is thus characterized by the fact that those who abandoned folk costume have paradoxically contributed to the preservation of it for a period of time. The change of traditional garments in many villages and costume groups could take decades even after abandonment became widespread, lasting well into the 1980s and 1990s.

Another aspect of the issue is that the inhabitants of the villages were aware of the changes taking place in their narrower or wider surroundings. They always knew where and how much abandoning was taking place, what you can get and where to get it. There was buying and selling of used costume pieces that bypassed the usual commercial avenues. Surprisingly, even geographically distant costume groups became aware of changes taking place elsewhere, possibly hundreds of kilometers away. For example, the wives of railway workers in Bag brought delaine and silk skirts from Mezökövesd and crepe de Chine fabric from Transylvania during the material shortages of the 1950s. In the 1970s, the people of Kalotaszeg bought cashmere skirts and shawls in several Hungarian villages of Nógrád, Pest, and Tolna counties, where costume abandonment took place recently. ${ }^{82}$ The examples could be listed at length.

It is a testament to the adaptive behaviors and "will to survive" of some of the ethnographic groups that, for example, enterprising Matyó women specialized in the production and sale of various pieces of costume in the 1930s and 1940s. These Matyó goods even made it to Transdanubia. Each woman had her own district encompassing several villages that she visited at regular intervals to fill orders. This is how the Matyómade shawls, bodices, aprons, and blouses found their way into the contemporary costumes of many villages. In some Palóc villages, for example, the so-called Matyó shawl became part of the contemporary festive attire. The Matyós tried to design their goods according to the tastes and wishes of the given village, and even met the needs of different strata. With their goods, they served not only the costumed peasantry but also the ones who cast off their costume, as well as the village craftsmen and intellectuals. ${ }^{83}$

82 To the knowledge of my informants, the Hungarians from Kalotaszeg were not just buying for their own needs; they also passed on the costumes brought from Hungary to the surrounding Romanian villages for good money.

Kalotaszeg is a Calvinist Hungarian ethnographic group of about 40 settlements, famous for its folk art, in Transylvania, near Cluj-Napoca, Romania. After the construction of the railway at the end of the $19^{\text {th }}$ century, the women of some of the villages of Kalotaszeg earned extra income through more mobile, savvy, peripatetic trading activities.

83 I collected the data in Mezőkövesd, Kazár, Varsány, in the Galga river valley, in Sióagárd, and Szebény. I also wrote on the topic in more detail in a separate study (FüLEMILE 1991a). The commercial embroidery activity of the Matyós is also mentioned in HOFER - FÉL 1975:51; FÜGEDI 1997:59, 118, 2001b:57; and KAPROS 2004:225-238. Research also clarified the role of the Jewish merchants of Mezőkövesd in the management and organization of embroidery activities (SZARVAS 1990). 


\section{ALTERNATIVES AND THE SIMULTANEOUS PRESENCE OF DIFFERENT STYLES OF CLOTHING}

The dress culture of the inhabitants of a village was not necessarily uniform even before the abandonment of traditional wear started. Individual strata and groups of a stratified rural local society may have followed different styles. ${ }^{84}$

During the abandonment process, there may have been alternative solutions for those who wanted to change. In the 1930s-40s in Kazár, for example, one of the options was the earlier mentioned Szele style or blouse costume in which only a few elements of the traditional costume were replaced. ${ }^{85}$ (This solution was cheaper, more accessible to poor or orphaned girls who wanted to retain peasant dress even in this form.) The other option was the so-called pleated skirt style, which, despite its urban look, actually served as a costume supplement. Its wearing did not mean that its wearer no longer wanted to look peasant. The emotional, identifying tenor of "our costume" thus survived partially. "Our costume was the pleated skirt, the colonists (i.e., the urbanized miners of the Colony) dressed differently, they wore dresses." The pleated skirt style was in fact a transition between peasant and urban clothing. Many pieces of the costume were altered to go with it, its relatively still fixed set of rules in many ways linked to the traditional costume. The tastes and knowledge needed for dressing of those who changed dress in this way did not go through fundamental changes, which also explains the success of this solution. In this era, few have yet opted for the third solution, urbanized dress and the "one-piece dress" - primarily those who came into direct contact with the city because of their work or marriage. This, according to their own admission, required more prosperity. In fact, it was an intentional expression of the new social rank of those who left or wanted to leave the peasantry. In the wave of costume abandonment between the two world wars, this kind of distinction between the "pleated skirt" and the "one-piece dress" can be observed not only in Kazár, but elsewhere, until perhaps in the 1950s.

The staunchly Catholic town of Mezökövesd, where many poor people earned money through seasonal harvesting jobs on big landed estates, was "famous" for its costume and embroidery. There was an oft-repeated saying among the peasants of Mezökövesd: "Don't care if the tummy growls, as long as the outfit vows." The discovery of the Matyó (a regional nickname) folk art of Mezőkövesd put the town in the focus of intellectual, middle-class, and tourist interest at the turn of the $20^{\text {th }}$ century (FüGEDI 2001a). Typical of the success story of Mezőkövesd was a 1912 event, an opera ball organized in Budapest, where aristocrats and elites dressed in Matyó peasant outfits. Middleclass traders organized a well-functioning network of cottage industry and merchandised Matyó embroidery not only in Hungary but in Europe and the States as well. To this day, Matyó "dolls" and embroidery motifs on miniaturized "gadgets" are some of the most marketable tourist souvenirs in folk art shops in Hungary.

${ }^{84}$ It goes without saying that the local landowner and everyone around him, as well as the intellectuals, the craftsmen, and the merchants dressed according to urban fashions before World War II. But there may also have been differences between certain groups of the peasant population. For example, if there was a manor in the settlement, alien, migrant servants also stood out in the way they dressed. In the case of religious and ethnic divisions, the local peasant population could also wear a variety of costumes. (A good example is the case of Érsekcsanád on the left bank of the Danube, where the Calvinists married into the villages of the Sárköz on the other side of the Danube and their costumes were related to those of Sárköz, while the Catholics living in the same village wore costumes that were different than those of the Calvinists.)

85 It is mentioned in footnote 43 too. 
Part of the truth is that nowhere has the process taken place in the same way. In some places the distinction between the 'pleated skirt' way of dressing and the 'one-piece dress' style that is truly urban is very much a conscious one. Elsewhere it did not occur in such a differentiated way, and it was just individual taste that determined who opted for which solution. Women who abandoned costume have certainly shown preference for wider (pleated) skirts and two-piece outfits long after abandonment. ${ }^{86}$ (Since the 1960s, however, a more direct adoption of urban fashions has been typical.)

In Kazár, each way of dressing encapsulates an independent structure of fixed rules. This is also supported by the fact that each clothing style includes a different dowry and funeral shroud. (I am referring here to the linens of the hope chest as well.) Clothing for the body is in line with the festive textiles of household furnishings. From this fact follows one of the characteristics of dress change, namely that "the two styles could not be mixed, you picked one or the other" (Mezökövesd), and "if you wanted to switch, you did not commix your costume with the urban clothes, you acquired what you needed and switched immediately, and then never wore the old ones" (Kazár).

Clothing style also required a certain kind of behavioral culture. Smoking, makeup, cycling, and other urban behaviors were alien to costume wearers, and could only be taken up after costume abandonment. Propriety determined what was permissible in costume and what was not. It was inappropriate, among other things, to smoke or ride a bicycle in traditional costume - things they began to practice in urban dress. ${ }^{87}$

Consistent adherence to the principle that the elements of each dress style should not be commixed is especially characteristic of villages that had typical, often "famous" peasant wear. While in some villages it may have been allowed to wear urban clothes one day and costume another, they still knew clearly what was appropriate to wear with each style of dress. For going to see a doctor, to the hospital, to the city, doing business in these places, they usually wore city clothes - so as not to subject themselves ridicule but within the village, or for certain occasions (e.g., holiday, wedding), they wore traditional costume. So the functions of the two ways of dressing were differentiated.$^{88}$

By the 1980s, in some villages, owning two types of wardrobes - urban and traditionalwas a sign of prosperity. Thus, the traditional costume becoming a status symbol can in some cases strengthen the desire to revive it (e.g., in Sióagárd).

In fact, it is also only by knowing the local development that one can determine whether the simultaneous acceptance of urban and peasant dress style and their differentiated use

86 See, e.g., Petánovics 1971:329.

87 This was true in the past at the time of costume abandonment, but it did not necessarily apply to the costume retention practices of the 1980s. Some of the women still wearing traditional costume at that time have accepted some elements of the urban lifestyle, e.g., in Zsámbok. More on Zsámbok costume, see PÉTERBENCZE 1990.

88 An interesting way of the simultaneous presence of peasant and urban dress is described in FÉL - Hofer 1969b:277. In Átány, while older women wore costume, marriageable girls and young women dressed in contemporary urban fashions. The dictators of fashion were the daughters and wives of prosperous farmers who had their clothes made by seamstresses in the city. Once their youth - when they followed the fashion of the capital - passed, they put on the dark-colored peasant clothing that was customary in the village. This way of dressing of young women, what they call stylin', has been observed since the late $19^{\text {th }}$ century. 
according to function is still part of costume abandonment, or more about today's rural lifestyle, the new possibilities of costume retention, or the new functions and meanings of the retained costume.

\section{CHARACTERISTICS OF 'UN-COSTUMED' WOMEN'S CLOTHING IN THE 1980S}

The relationship of 'un-costumed' women to clothing has retained many traditional features. In villages where the costume worn by the older generations still retained its richness of form and expression, those who abandoned costume still had strong ties to it, and local taste left its mark on their clothing (e.g., in Bag). Their use of materials and colors, their choice in fabric patterns, and their holding onto the wardrobe they once assembled was reminiscent of their peasant costume. Many still wore the collared, button-down shirt dresses fashioned from the overskirts of costumes as everyday wear upon their abandonment of the costume. (Figure 20,21) They still clung to certain traditional pieces of clothing (headscarf, apron for housework). ${ }^{89}$ They did not follow fashion - their clothes were discarded only when they became worn out. The characteristic elements of their attire represented a more conservative style of the urban fashions of the 1960s-70s (i.e., when they were abandoning their costume). (Typical pieces of clothing included: "one-piece dresses" made of synthetic materials, two-piece suits, blouses, housecoats, trench coats, fabric coats, knitted blouse-cardigan sets, a couple of basic leatherette bags.) They purchased some garments that went with their urban attire (bra, nylon stockings), but since these were alien to them, they did not wear them at all or only rarely, e.g., to a doctor's appointment. But at the same time, they showed off their wardrobe, which seemed meager by city standards, just as proudly as costume wearers who were accustomed to the fact that the dowry was subjected to public scrutiny.

Theoretically, they were also aware of the differences in forms of movement, walking, posture, gestures. Women recall how they learned the proper body technique in their youth. While wearing a costume required a firm, straight posture, restrained movements and gait, or a certain hand position, movement in urban dress was more laid-back, more relaxed. I was told that before costume abandonment, village girls or young women exercised how to move and walk in urban clothes in small groups of friends or neighbors. However, in spite of all their efforts, the movements and motor habits of the women who took off their costume did not change much, and their posture and gait, despite their intentions, remained the same as when they were wearing it. "They didn't understand how 'genteel' clothes were supposed to be worn, they were born into the other kind," said a woman from Mezökövesd. ${ }^{90}$

It might be added that 'un-costumed' women become more laid-back as they age, pay less attention to their appearance, and automatically return to certain old habits. This

${ }_{89}$ In Kazár, for example, the typical Palóc load-carrying equipment, such as the hamvas (a type of tablecloth) or the four-legged satchel (a crash cloth satchel that can be worn as a backpack) were still used for certain types of work by those who no longer wore costume.

90 Here we refer to the fundamental study on body technique by Marcell Mauss 1973. It is also worth noting here that Edit Fél pointed out the differences between traditional movement and gestures necessitated by costume and urban movement after abandonment of costume in Mezökövesd, also 
can also be said for their hair style. In Kazár, for example, most of the 'un-costumed' women wore short, permed hairstyles at a younger age, but as they aged, they adopted a simple bun almost without exception. One of the emblematic elements of this rural, provintial dress for middle-aged and aged women was the otthonka (housecoat), an everyday garment commonly worn from the 1960s and 1970s, which was a sleeveless or sleeved straight line housedress that buttoned at the front (BALI 2010). ${ }^{91}$ (With this, the elderly women would even wear a headscarf not only on the street but also at home.) (Figure 23)

All in all, a general uniformity characterized this first generation of "dissidents of tradition," and in most cases they were unable to develop a unique, individualized taste. Despite their desire to assimilate to the city, the first generation to abandon costume remained fundamentally peasant in taste and provincial in appearance. Provincial dress after the abandonment of traditional costume is no longer tied to a cultural group in the ethnographic sense, but it communicates the social affiliation and education of its wearer at first sight. ${ }^{92}$

draws attention to the fact that theoretical knowledge of ideal movement does not necessarily mean its perfect execution. "Even though we have abandoned our costume, we can still be recognized." "We were born Matyó, the Matyó people will never be city folk", she cites her informants, and adds, "That is, they are very much aware that their 'urban' posture and movement are still different from those of real urbanites, and do not even believe that they can catch up to it in modernity, but remain midway to it, looking ahead with constant nostalgia. But they also keep looking back with nostalgia" (FÉL 1952:410). Katalin Gergely's observations also confirm that the forms of movement required by costume "survived for a long time after taking off the costume," "the usual motor movements do not serve to display the new style of clothing, but to draw attention to the disharmony between the two" (Gergely 1981:231). PetánOvics 1971:329 also observes the same phenomenon.

91 They may have had it specially made, but most often they bought it as a ready-made garment, or on the black market. (In the second half of the 1960s, first half of the 70s, there was a specific black market for housecoats, too. The select few who had the opportunity to travel west so early on imported these much-sought-after, in-demand, brightly patterned housecoats made of synthetic materials, from the sale of which they could supplement their meager earnings.) To this day, it can be found in the offerings of clothing vendors frequenting rural fairs and weekly markets.

92 However, my collection experiences in Madocsa on the Danube and in Apátfalva on the Southern Great Plain (as well as family photos from the 1920s-30s) are a reminder that there may be other alternatives to the course of costume abandonment and post-abandonment urban dressing in the case of peasant-bourgeois type costumes than the ones described above. The research carried out in Kecel on the Great Plain also seems to prove this. "With the vanishing of an easily adaptable style, which has always been open to urban fashions, there wasn't such a sudden halt and confusion in style, and consequently the adoption of a completely styleless, homogeneous urban style; instead, a tasteful, eclectic, fashion-conscious urban style appeared in Kecel." (Gergely 1984:817). Throughout her collecting (Varsány, Kecel), Gergely pointed out certain persistent traditional features not only in the clothing of the first generation of costume abandoners but also in the urban dress of the younger age groups who have never worn costume, such as the principle of quantitative accumulation in the compilation of the dowry and a preference for home-made over ready-made, by accepting "the mediation of a specialist, the seamstress" (GERGELY 1981:228-229).

In any case, it is certain that in the 1960s and early 1970s, having clothes custom-made by a dressmaker was much more common, not only among peasants but also among workers and urban intellectuals, than in later years. This can be partly explained by the traditional prestige of smallscale crafts and the tailoring industry held over from the past, and the ready-made garment industry being in its infancy. Going to a dressmaker began to peter out only in the second half of the $1970 \mathrm{~s}$ and the first half of the 1980s. 
It should also be mentioned, that there were certain common elements in the dress of both those who retained costume and those who abandoned it. They all wore the same ready-to-wear shoes, sandals, stockings, bag, knitted vest, cardigan (bought from the department store or from clothing vendors frequenting rural fairs and weekly markets) and round bun. Interestingly, these were the elements that at the time of their emergence seemed most detrimental to costume, but instead they became the most invariable, most enduring, almost 'uniform' elements of provincial dress. (Figure 22, 24)

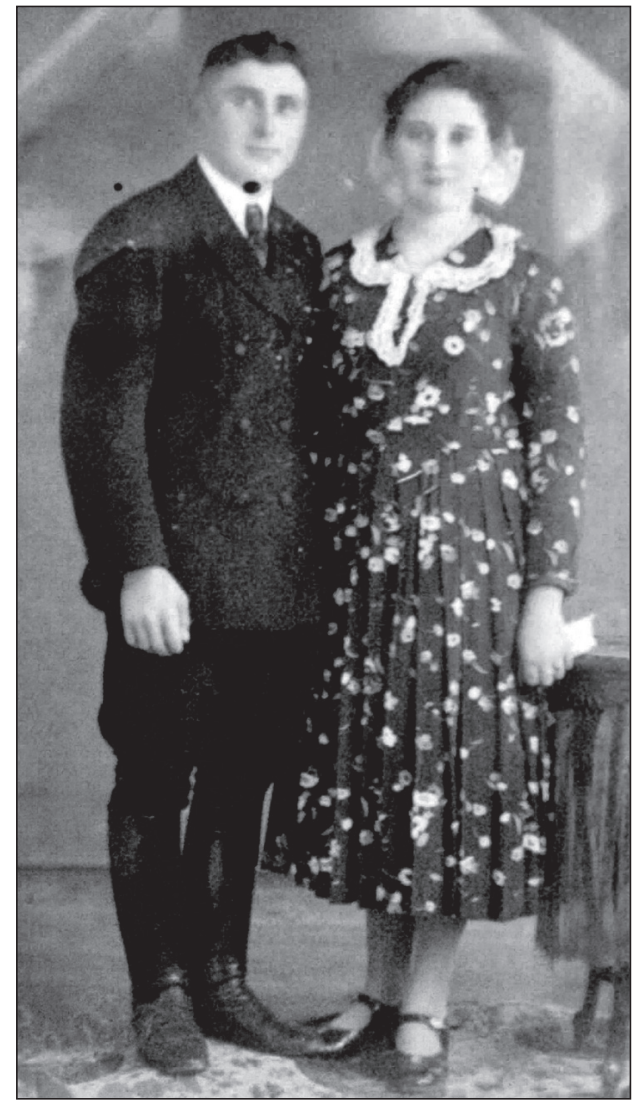

Figure 20. Engaged couple in Apátfalva (Csongrád county) in 1940. Dress with a pleated skirt made of a floral fabric to suit local costume tastes, buckled shoes, and a large bow in the hair of the 18-year-old bride-to-be. (Photo privately owned)

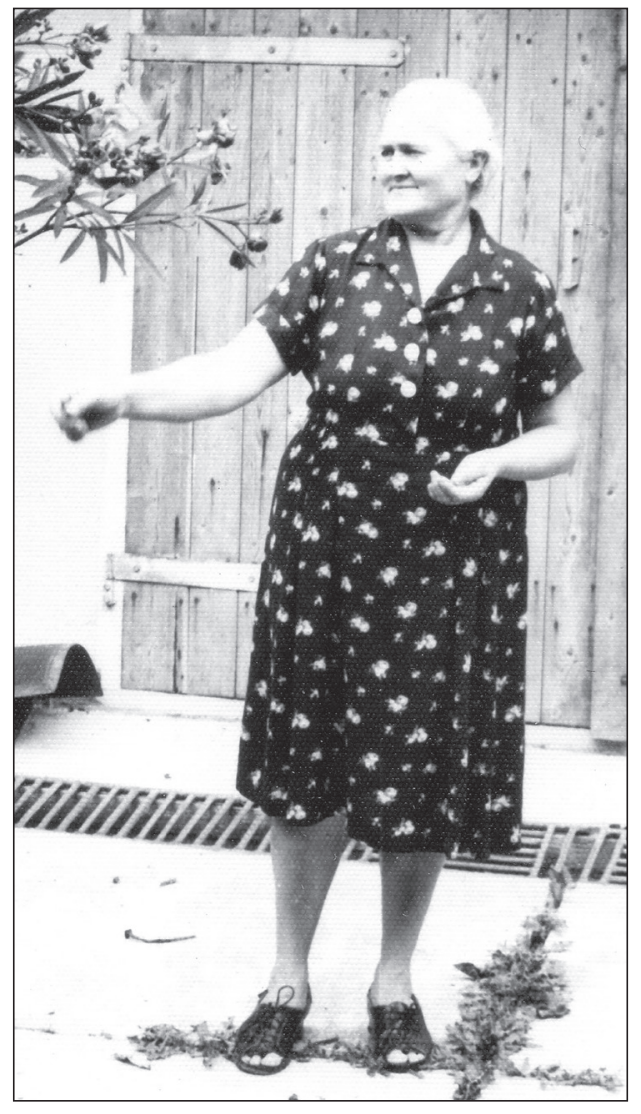

Figure 21. A woman who cast off her costume in the 1960 s, wearing a dress sewn from the remnants of her traditional skirt after abandonment, Kazár (Nógrád county), 1986. (Photo: Ágnes Fülemile) 


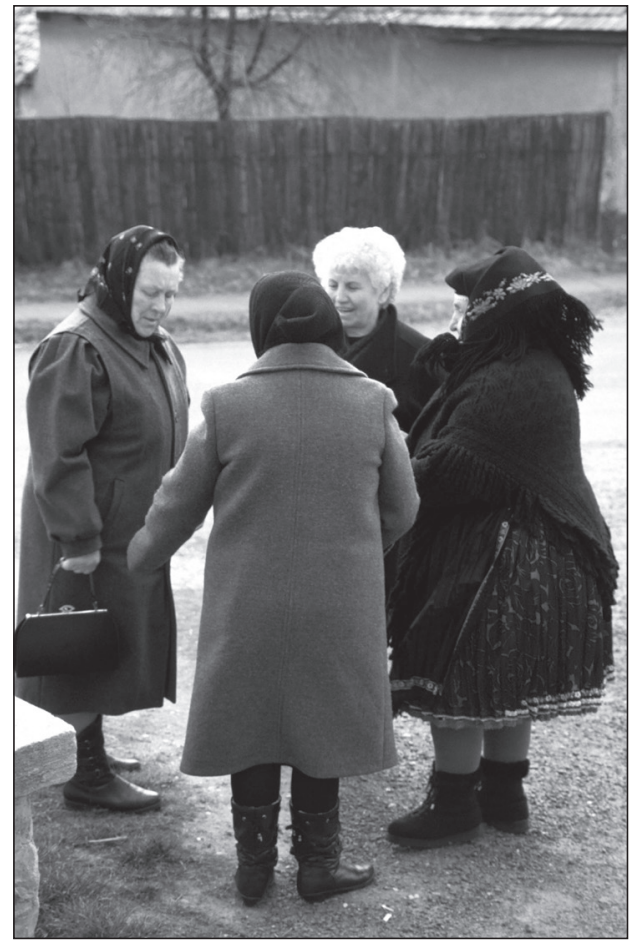

Figure 22. Women in costume and urban dress after Sunday Mass. Kazár (Nógrád county), 1986. (Photo: Ágnes Fülemile)

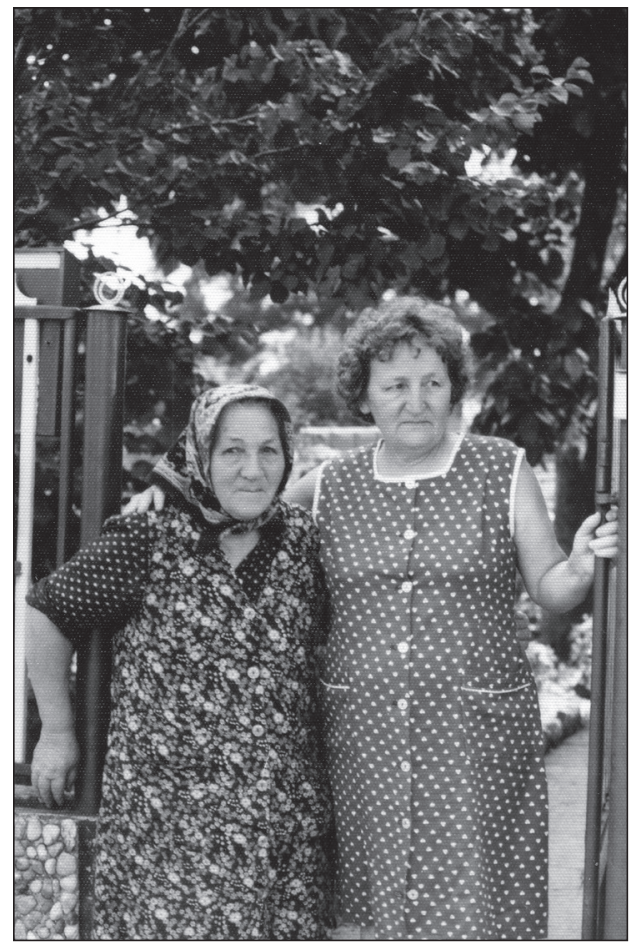

Figure 23. Mother and daughter at their gate in otthonka/housecoats. The older woman's hair is still covered with a headscarf, her middle-aged daughter has a short, permed hairstyle. Dúzs, (Tolna county), 1987. (Photo: Ágnes Fülemile)

\section{THE EVOLUTION OF THE “RETAINED” COSTUME AFTER ABANDONMENT}

After the conclusion of the period of costume abandonment, the development of the costume still worn by the older generations of women did not halt. On the one hand, there is a preference for practical, opportunistic solutions that have facilitated the dayto-day practice of wearing costume and taking care of one's outfits. On the other hand, the age-restricting functions of dress are relaxed, and aesthetic aspects and the role of individuality come to the fore.

The most striking change is that the age limits for wearing youthful colors, materials, embellishments, and garments have been pushed out. The restructuring of the rules was also due to the fact that, as one informant put it, "It used to be that they took off the fancy clothes because they had to pass them down to the next person, but now there's no one to give it to, so we just wear it." Thus, with the younger generations exiting the cycle, the obligation to pass on objects and the process of passing on knowledge ceased. Moreover, community control diminished and the numbers of those who knew the rules shrank. Given the surplus clothing available (Figure 25), the more expensive types of materials 
that used to be considered festive were being worn for half-festive and everyday errandrunning ${ }^{93}$ occasions, too. (Figure 27,29) Another trend-like change is that festive formal wear has been simplified in such a way that the once-ordinary errand-running outifts could be worn to church on major holidays. (It is not about the quality of the material, but the selection of garments needed to assemble the outfit itself.)

The response to contemporary fashion was the length of the skirt getting shorter, which began as early as the turn of the century and continued into the 1960s and 1970s, and in some places accelerated almost to an extreme. At the same time, the skirt flattened out with less and less petticoats underneath to make it easier to wear, not pulling at the waist. (Figure 26)

Under urban, bourgeois influence, undergarments appeared in peasant clothing only in the interwar period, primarily as home-made articles sewn from cambric. This type of underwear was replaced by store-bought underwear in the 60s (undershirts, underpants, tank tops, panties, stockings). ${ }^{94}$

In addition to diminished community control, individuality comes to the fore. According to their personality, mood, knowledge and taste each person paid more or less attention to their clothing and its care. Some favored simpler solutions and practical innovations. Others playfully took advantage of the late opportunity for fancy, youthful dress. Often it led to overindulgence, a distortion of style, even dowdiness. ${ }^{95}$

93 Ide-s-tovamenö / errand-running or jönni-menni / come-and-go costume is a semi-formal attire for running administrative errands, going to the town-hall, school, rectory, doctor, city, market, shops etc. A fine analysis of the wardrobe and dressing practices of a woman from the village of Patak, who happened to be the cleaning lady at the Palóc Museum in Balassagyarmat, written by museologist/ethnographer Márta Kapros, who documented and studied the woman's come-and-go costume repertoire day after day throughout an entire year in 1985. KAPROs 1991, 1994, 1995.

94 Note that in villages, urbanized underwear, underpants with long legs and stockings, started to be worn under the traditional upper garments only from the 1930s-40s. Bras and short-cut pants were worn by women in the countryside only from the 1960s-70s.

95 The best examples of the difference in mentality expressed in clothing are Bag and Zsámbok. The two villages are not far from each other, both located near Gödöllö, and although they do not belong to the same costume group, they have a similar economic and social background. Nevertheless, their dress strategy, their costume culture preserved into the 1980s is different, having retained and highlighted different elements of the costume as the characteristic, significant element of their dress. Zsámbok - where the age of those still wearing costume was the lowest of the villages studied, 42-43 years old in 1987 - was characterized by a spirit of constant experimenting innovation, the acceptance of elements that might have seemed extreme. Their new use of costume may seem more exhibitionistic and provocative compared to the traditional. Costume in Bag, on the other hand, was characterized by restraint and respect for traditional solutions both in the past and in the studied period. There are no radical changes, even the preserved costume is simpler than that of Zsámbok, but it is still definitely local in nature. 


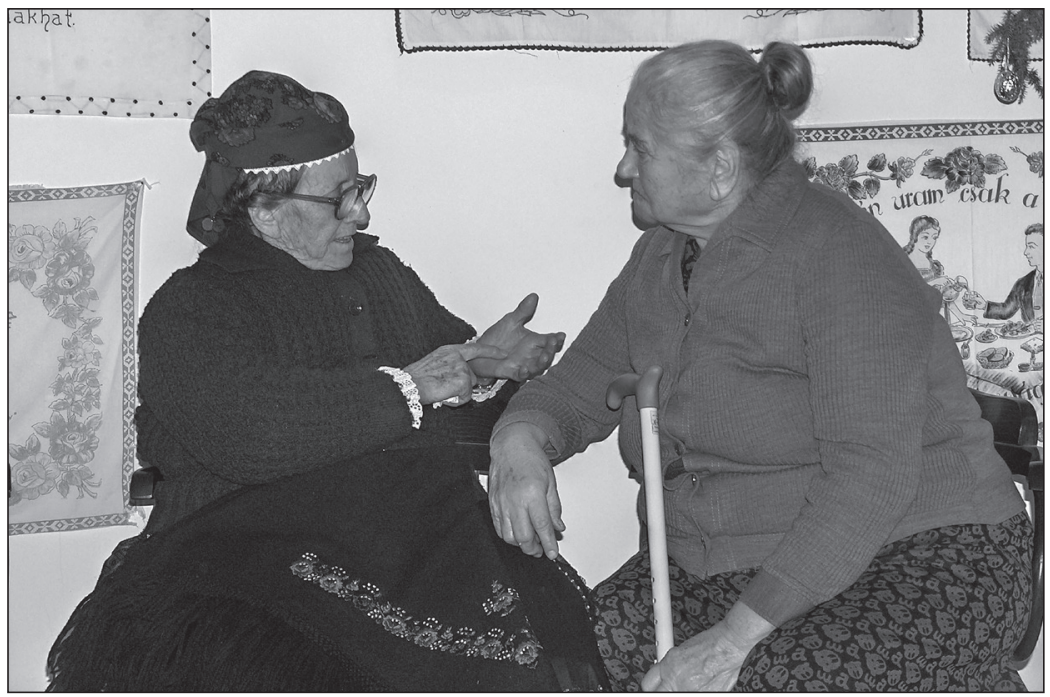

Figure 24. One of the last women, Aunt Panni to wear costume, and her neighbor Aunt Piroska, a good friend a few years her junior who abandoned costume as a girl, at a village ceremony in Kazár, 2005. (Nógrád county) (Photo: Ágnes Fülemile)

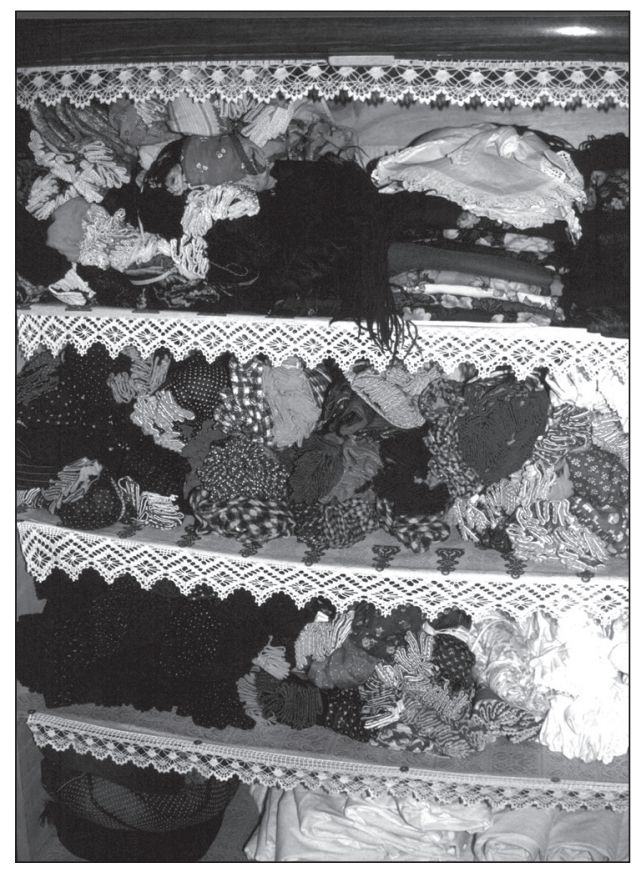

Figure 25. One of three storage cabinets of the rich wardrobe of Aunt Panni. The two middle shelves hold her overskirts. 2002, Kazár (Nógrád county) (Photo: Ágnes Fülemile)

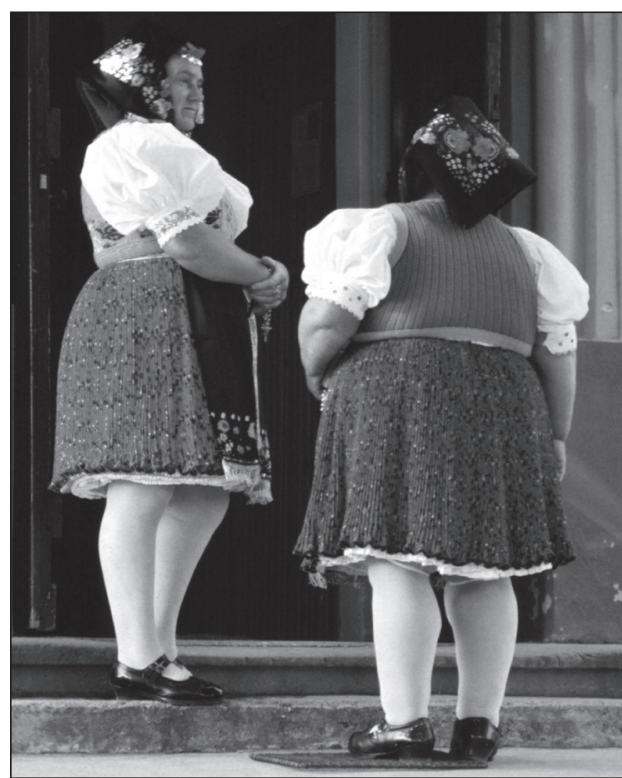

Figure 26. Middle-aged women in costume, dressed in colors befitting younger women and wearing skirts shorter than usual, with fewer petticoats than usual. Dressed for mass on the feast of the church's patron saint, Varsány (Nógrád county), 1987. (Photo: Ágnes Fülemile) 


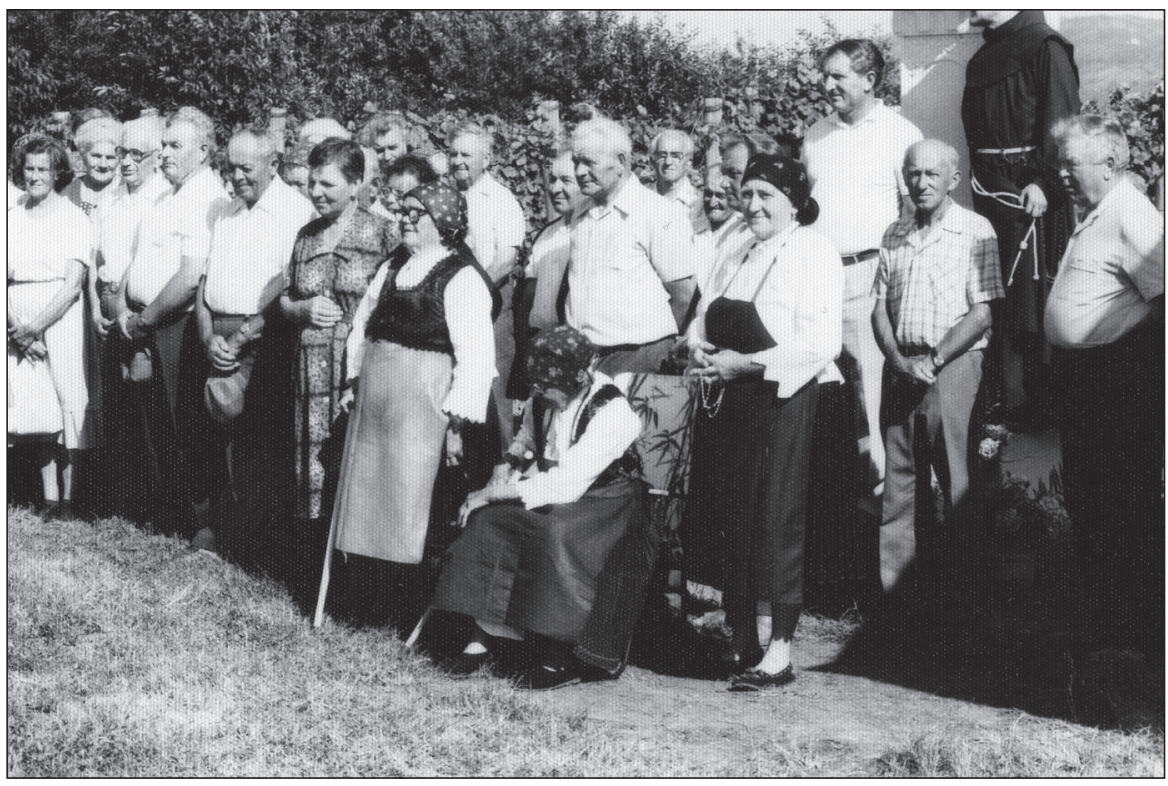

Figure 27. Consecration of a cross in the vineyards on a Sunday afternoon. Sióagárd (Tolna county) 1987. (Photo: Ágnes Fülemile)

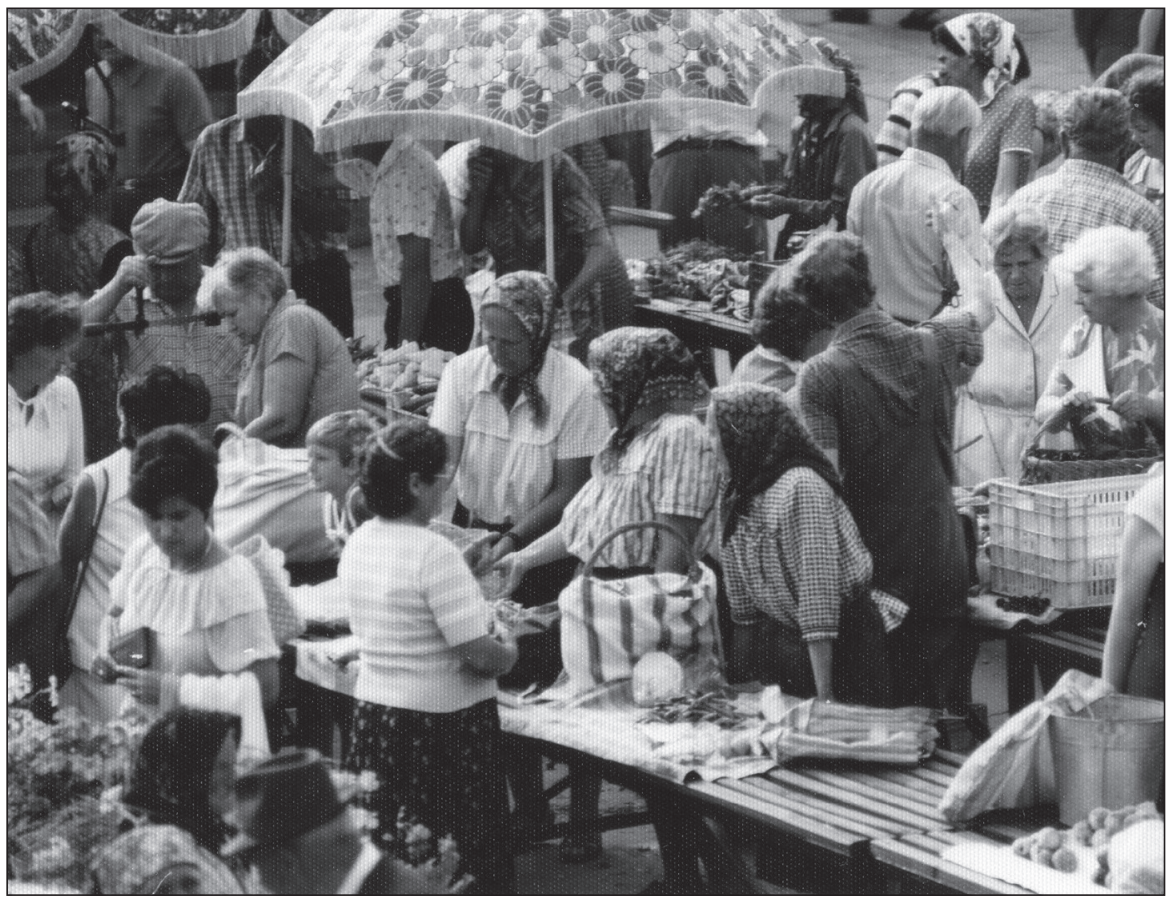

Figure 28. Women from Bogyiszló selling their goods at the weekly market of the county seat, Szekszárd, 1987. (Tolna County) (Photo: Ágnes Fülemile) 


\section{THE “UNIFORMIZATION” OF COSTUME}

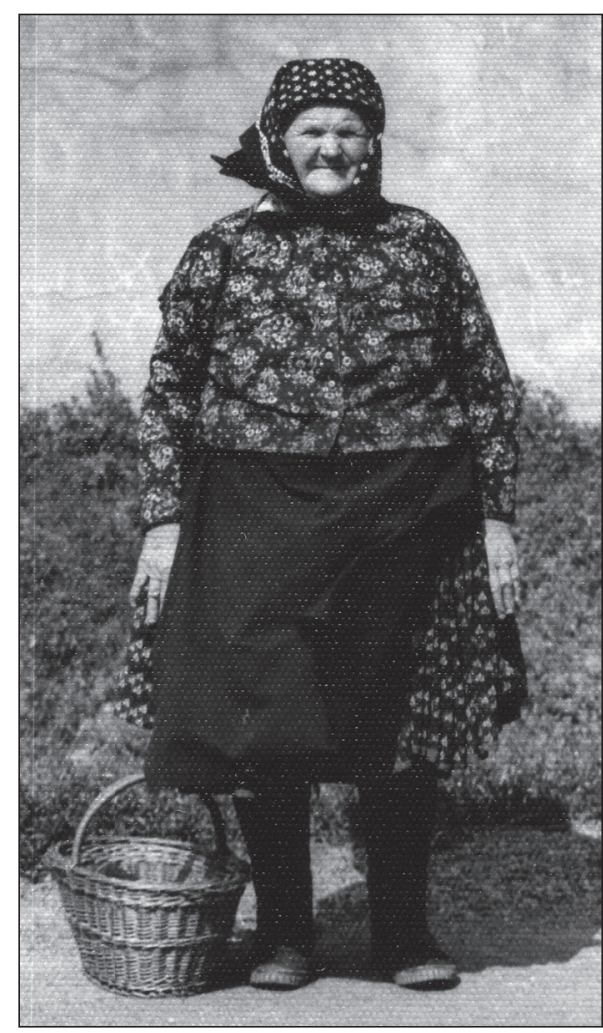

Figure 29. A woman from Váckisújfalu in the neighboring Galgamácsa (Nógrád county) in an ide-s-tovamenő (errand-running) outfit. 1987. (Photo: Ágnes Fülemile)
By the 1980s, the costumes retained in each village were at different stages of becoming "lackluster". This process of becoming devoid of substance and form is what I call uniformization. There is a stage in the process where the local character is still recognizable, with a specific element still identifying the dress. (Figure 29) Another phase is when the costume is already deprived of its expressive power in terms of substance and form, and is cemented in a substance-free, static form, the process of its creative development stalled. The final stage is a nondescript provincial "elderly wear" found all over the country devoid of local character. (Figure 30)

In addition to the group of costumes retained after abandonment that still have a relatively rich expressiveness and peculiar local style (which we outlined in the previous subsection, such as Kazár, Zsámbok, Varsány, Sióagárd), I consider it worthwhile to establish the following additional categories:

- local costume showing signs of uniformization (e.g. Galga river valley, Sárköz, Bogyiszló) uniformized costume with a local character (e.g. Zengővárkony) elderly wear devoid of identifying features (e.g. Kapos river valley, Szebény).

Costumes that had retained their local character at the time of my study had a couple of characteristic elements making the costume unique and recognizable. What they retained as their most characteristic, significant element does not seem to be random. The wide skirt is uniformly everywhere the most important element of peasant dress, along with the apron. The importance of the skirt is demonstrated by the fact that it was the guiding piece, when assembling an outfit. ${ }^{96}$ Costumed women also name different

96 The composition of an actual traditional outfit in the past and still in the time of the study, started with picking the skirt appropriate for the occasion (in material, color, pattern, and embellishment) and then the other pieces of the outfit were matched to it, a proper shawl or vest, and finally an apron and headscarf. Coloring changed with the age of the wearer and the rank of the occasion. Colors were ranked differently; there were more festive and less festive colors. In some regions, even each of the four Sundays in a month had a required color in the order of rank, the first Sunday being on the top of the hierarchy. 


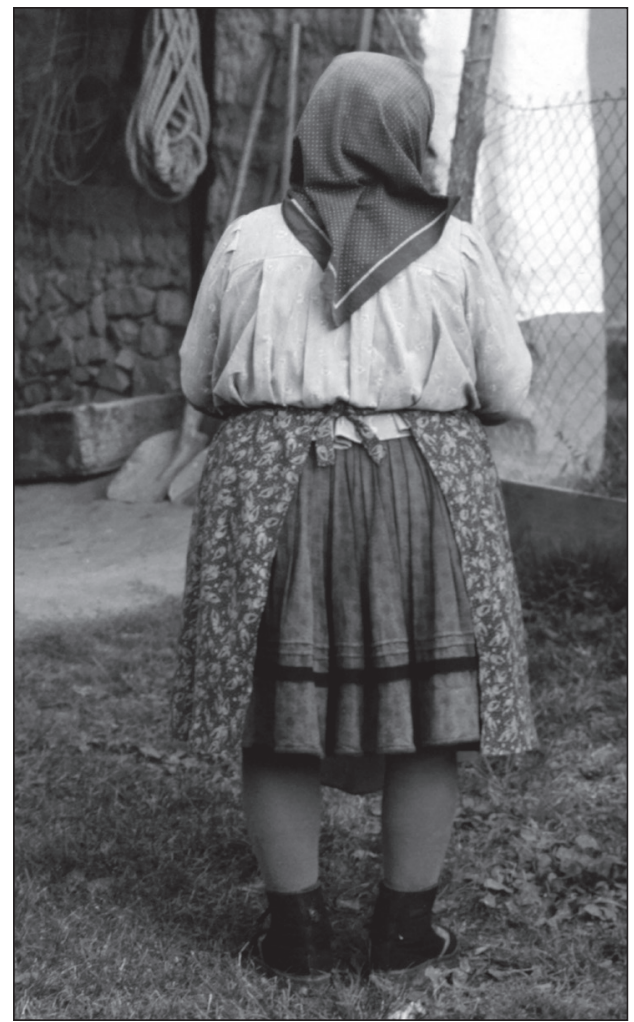

Figure 30. Woman dressed for work around the house in Szebény, 1987. (Baranya county) (Photo: Ágnes Fülemile) dress styles based on the differences in the skirt; wide skirt, pleated skirt, straight skirt, gathered skirt. In addition to the skirt, headgear can be a significant element of attire - see, for example, the distinctive ways of tying a headscarf in Kazár, Bogyiszló, Sárköz, Sióagárd. In Zsámbok, the small cap-like bonnet covering women's buns - which, without exception, is worn by everyone, even with the most spectacular outfits - almost seems to be an attribute of costume wearers. The women of Bag, on the other hand, can be seen without a headscarf, with an uncovered bun (a surprisingly relaxed solution in sharp contrast with former traditional propriety), and besides the skirt, their costume is characterized by the slimmer. This one form of blouse is worn uniformly.

My use of the term elderly wear needs the most explanation. By this I mean that there were standard clothing elements that the elderly wore that could be observed nationwide in rural areas, or among elderly rural people who moved into the city to live with younger family members (e.g., in a housing estate), or even among the residents of nursing homes. A headscarf, a skirt tied at the waist and topped with an apron for holidays, invariably gave them the familiar senso-motor feeling of traditional dress. As these women say, "I like it when the skirt is tied tight around my waist," or "I cannot stand being without a headscarf, I feel cold." This internal attachment to the physical and social patterns of dressing, commensurate with their sense of shame arising from their upbringing and a "what's proper - what's not" behavioral norm (they felt as if they would be ridiculed if they went outside without a scarf or in city clothes), made these reflexes endure even when everything around them was gone already. The process culminated in this stage, this is the end point. There was no more tradition, no more expectations, the medium that may have judged compliance with the norms was gone, there was nothing left but the automatisms of their own narrow inner world. 


\begin{tabular}{|c|c|c|c|c|}
\hline Name of locality & $\begin{array}{l}\text { The youngest age group } \\
\text { still wearing costume }\end{array}$ & $\begin{array}{l}\text { The most intense } \\
\text { period of costume } \\
\text { abandonment }\end{array}$ & $\begin{array}{l}\text { The character of the } \\
\text { retained costume }\end{array}$ & $\begin{array}{l}\mathrm{T} \quad \mathrm{h} \quad \mathrm{e} \\
\text { intensity of } \\
\text { revival }\end{array}$ \\
\hline Zsámbok & $43-44$ & Late 1950 s, early $60 \mathrm{~s}$ & typical local & ++ \\
\hline Varsány & $43-44$ & $1960 \mathrm{~s}$ & typical local & ++ \\
\hline Sióagárd & $\begin{array}{l}\text { General wear for } \\
\text { those around } 70 \text { and } \\
\text { occasional wear for } \\
\text { those aged } 50-70\end{array}$ & early $1960 \mathrm{~s}$ & typical local & ++ \\
\hline Galgaguta & around 50 & Around 1960-70 & typical local & + \\
\hline Bag & around $55-60$ & early 1960 s & typical local & + \\
\hline Kazár & around $55-60$ & early $1950 \mathrm{~s}$ & typical local & + \\
\hline Bogyiszló & $45-50$ & $\begin{array}{l}\text { Between } 1960 \text { and } \\
1970\end{array}$ & $\begin{array}{l}\text { local costume showing } \\
\text { signs of uniformization }\end{array}$ & + \\
\hline Zengővárkony & around 70 & Late 1950 s, early $60 \mathrm{~s}$ & $\begin{array}{l}\text { uniformized costume } \\
\text { with a local character }\end{array}$ & + \\
\hline Szebény & around 70 & $1950 \mathrm{~s}$ & elderly wear & + \\
\hline Regöly & around 70 & $1950 \mathrm{~s}$ & elderly wear & - \\
\hline Hosszúhetény & - & $1950 \mathrm{~s}$ & - & - \\
\hline Apátfalva & between 1920 and 1930 & & - & - \\
\hline Madocsa & between 1920 and 1930 & & - & $\mathrm{X}$ \\
\hline \\
\hline Legend: & \multicolumn{4}{|c|}{$\begin{array}{l}+=\text { revival } \\
++=\text { intense revival } \\
-=\text { none } \\
X=\text { instead of costume, the Hungarian dress is typical }\end{array}$} \\
\hline
\end{tabular}

Table 1. Data on the abandonment and retention of costume from 1987 (select research sites)

\section{THE EMOTIONAL VALUE OF COSTUME}

There may be several motivational factors behind costumed women's emotional attachment to costume: generational situation, respect for traditions inherited from their families, or merely individual inclination. There are examples for each. In Kazár, for example, two generations of women who remained in costume until the mid-1980s could be distinguished according to their relationship to tradition. For those over the age of 65 , who were young before costume abandonment became widespread, it was natural to continue wearing it. Their position in favor of peasant costume could not be changed even by the public mood of the 1950s. "Well, I'm a peasant, I can't be ashamed of my costume. Many times I was ridiculed for it, they said, here come the peasants. Well, if they come, they come. We couldn't dress like the gentry, a peasant could only wear the clothes he was born into". Some women in the 55-65 age group who remained in costume - the young women of the 1950s did not cast off their costumes even during the most intense wave of abandonment. For them, costume abandonment was a real challenge. To undertake a path followed by only a 
few in a time of change required a strong individuality and a deep emotional attachment to tradition. Just how much these women felt the need to wear costume is also demonstrated by the fact that they did not take it off even upon medical recommendation. "I love having my skirt tight. I wouldn't wear it loose, it feels good, far from being uncomfortable."

Even those who took it off out of necessity have a strong emotional attachment to the cast-off costume. Years after abandonment, they still look back on it nostalgically as a missed opportunity, an unfulfilled desire of their lives: "I'm still heartbroken over it today, I loved it so much, I would love to wear it even now" (Bag). "All those folks became like gypsies, we even cried over it. They wept over me, too, when I took it off" (Mezökövesd).

An interesting example of the love of costume is the story of a woman from Bag. She came from a poor peasant family, always striving to help herself in some way. Her husband was a drunk, a wicked man. She endured it silently, until one day she spoke up, asking why they had to live like that. In revenge, her husband set fire to the room where the woman's clothes were, and then he stepped in front of a train at the end of their garden, where the embankment ran. The woman was left alone with her two sons, they had to endure the shame. She has been through illnesses, weddings, funerals since then, all by herself. She had no money to get costumed again. She started a collection. She made life-size dolls and dressed them in the costume of Bag. She is very knowledgeable about the rules and history of costume. Little by little, she accumulated furniture and a complete wardrobe of men's and women's dresses, and over time she set up one of the rooms in her house as a museum. She was motivated by her love of costume and, after her own tragedy, the opportunity for prominence and self-realization. Of her special doll museum, she said: "I poured my sorrow and my joy into this. At night, when I was making them, when I got stuck, I prayed to Mary for help." The "torching", which encapsulates all her tragedies, has grown into a symbol in her life - like a ballad refrain, she would always bring it up. (Figure 44)

The prophetic narrative topos of "torching" and "destructive fire" is often articulated by others as well when I ask older women who cling to their costume about the fate of the costume. The members of this dwindling, small group followed and experienced the displacement of tradition with painful awareness. Their focused attention, experienced with deep emotions, captured every moment deep in their memory. "This is my death, this costume." "I always grieve when I think about the fate of it. It will end up in a bonfire. I am exactly like my mother. I would die for it just so they wouldn't throw it away."

\section{REVIVAL PERIODS AND THE AFTERLIFE OF THE REVIVED COSTUME}

The discovery of peasant culture by non-peasants (elites, intellectuals, artists, scholars, urban middle class, political parties, entrepreneurial agents, tourists, etc.) and the evolution, use, reinterpretations, or exploitation of the concept of the "folk" played an essential role in the "invention" of East-Central European national cultures and ideologies. The complex phenomena of 'folklorism'97 are specific products of

\footnotetext{
97 Folklorism is a conscious value-fabrication process, a result of the interest of other social groups in the folk culture of "peasants". In a nostalgic search for authenticity, certain cultural elements were highlighted, reinterpreted, revived, reapplied, and inserted into other contexts to achieve new meanings and symbolism.
} 
the convergence of 'rurality' and 'urbanity'. As a result of the encounters, there is a sensitive interplay between external image versus internal self-image. Influences (both negative and positive) and encouragements from the outside and the image of the peasantry in official politics, public thinking, and culture naturally affect the wellbeing, self-esteem, and ambitions of the peasantry. Out of the several waves of folk revivals, two should be mentioned which had an important influence on the longevity of folk costumes.

As an example, I cite the Gyöngyösbokréta (Pearly bouquet) movement (19311944) organized by journalist Béla Paulini (PÁLFI 1970). It established and brought village dance groups from all over the country (including parts re-annexed during World War II) to Budapest, in order to present folk traditions to the upper-class audiences of the capital on the stage of the City Theater (today's Erkel Theater) and in the St. Stephen's Day procession. ${ }^{98}$ Perhaps one of the merits of the movement was that it made the young participants, and through them their village communities, aware of the values of their own culture, thereby giving them self-awareness and self-esteem. Not a negligible aspect for ethnography is the fact that the list of villages embraced by the movement in the 1930s was a selection of villages which still had a relatively lively peasant culture at the time (primarily in terms of dance, music, costume, customs). The Gyöngyösbokréta, even if schematized according to the requirements of stage choreography and presentation, nevertheless made them aware of and passed down to them traditional material that would become the basis for the preservation of traditions decades later (DiósZEGi 2008).

Of the villages I studied, 17 were once "bokréta" members (most of them had a costume that was "still alive" in some form at the time of the study), and with one or two exceptions, there was a heritage preservation group or folk dance ensemble in each village. Local folk dance ensembles, on the other hand, were among the initiators and protagonists of the contemporary revival and preservation of tradition as the motivators of the revival.

The effect of the nostalgic folk revival of the 1970s is also detectable. From the turn of the 1970s the nation's attention turned to folk culture, televised folk song contests were broadcasted, folk singing circles and dance ensembles were formed (Fly Peacock

The debates over folklorism in Hungarian ethnography and European ethnology were particularly lively in the 1970s, 1980s, and 1990s. A survey of these - with a useful bibliographic overview from an American perspective - is provided by Šmidchens, Guntis 1999. The elaboration of the theoretical framework of folklorism studies in Hungary was pioneered by Vilmos Voigt, who devoted several works (not listed here) to the issue.

98 Between the two world wars, the romanticized, theatrical, and festival-like showcasing of the countryside - a counterpoint to Budapest as a worldly metropolis - played an important role in the redefined touristic self-image of post-Trianon Hungary struggling with the trauma of significant territorial losses after World War I. (The Trianon Peace Treaty of 1920, which disintegrated the territory of the Hungarian Kingdom, is named after the chateau in Versailles, France where it was signed.) The folk motif use of Hungarian 'Art Deco' artists of the 1930s and '40s, the patriotic Hungarian-style dress movement (marked by the names of Ferenc Ferenczy and and the Budapest Pántlika Salon of the designer Klára Tüdős) and the Gyöngyösbokréta movement, all fit into this trend. 
Movement $)^{99}$, organized and spontaneous revival movements started, and the tangible and intangible products of folk art in general came to be valued more. The táncház (dance house) movement that began (in 1972) at the initiative of urban youth, was named after its effort to reinterpret the tradition of village dance events in an urban environment. The remaining latter-day scenes of peasant culture were reached by the village discovery of the 70s at a time when an older generation possessing traditional knowledge was still alive. The quest for original traditions encouraged the best of the movement to learn the rich set of dance and music motifs, techniques, and performance styles from the last remaining village musicians and dancers in Hungary and beyond its borders, in the villages of lands inhabited by ethnic Hungarians. The folk revival movement that married craft, ${ }^{100}$ music, and dance offered a refreshing alternative to the ideological, controlled socialist youth activities of the 70s and 80 s. The vibrant sound of the newly discovered authentic music, the liberating feeling of improvisational movement, the joy of creative activity, and the social experience of the fellowship of like-minded young people all contributed to a critically minded young generation's expression of rebellious worldviews. The folk art movement as a phenomenon can be interpreted as a nostalgic counterculture to the Goulash Communism of the Kádár era. ${ }^{101}$ (Figure 31)

Partly as a result of the dance house movement there was a growing interest in the revival of local costumes as well. (In their "quest for the authentic," urban young people eclectically mixed original peasant garments with their jeans and urban dress.) Interest from the outside brought to life a conscious preservation of tradition in many villages as well. (It was undoubtedly a positive feature of the process that, although it could not reverse the changes, the nostalgic look back at their past gave the inhabitants of these villages a new sense of self. (There were negatives as well, of course, such as the commercialization resulting from serving tourist interests, or the creation of poor-quality, cheap products.) Depending on the temporal distance from the time of the disintegration of peasant culture, villages were more or less successful in recovering and accurately reconstructing the abandoned costumes as a new expression of rising local identities, used mostly on stage or in quasi-traditional events described as folklorism. (Figure 32, 33)

In the process of reviving folk costumes in the 1980s, there were several different attitudes in the relationship of rural communities to tradition. Where the continuity of

99 Röpülj páva (Fly Peacock) was a televised folk song talent show in 1969-1970. Other Fly Peacock contests were organized in 1973, 1977, 1981, and 1983. With only one TV channel in the country, the sole medium enjoyed enormous publicity. The show accelerated the establishment of several Fly Peacock circles (Pávakör/Peacock Circle) in many localities in the countryside. The show brought "heritage preservation ensembles", choirs and zither bands, middle aged and elderly women and men dressed in the traditional or quasi-traditional costumes of their villages into the spotlight. As a result, people began to see the value in their recently abandoned local folk culture. For more on folk talent shows, see: BALOGH - FüLEMILE 2008:47, 48, 59.

${ }^{100}$ Members of the so-called nomadic generation folk craft movement that was gaining ground around the same time were also motivated by the preservation of the traditional knowledge of vanishing crafts. In contrast to the template-based market production practice of socialist-era cottage industry cooperatives that left the patterns of folk art devoid of meaning, they explored the deeper, meaningful layers of peasant culture, the possibilities of preserving natural artifact creation and traditional complex knowledge.

${ }^{101}$ On the folk art movement of the 1970s and 80s as a form of grassroots resistance of urban young people in socialist Hungary, see BALOGH - FÜLEMILE 2008. 
the costume culture was interrupted, there was no mediating stratum, and the revival had a reconstructive nature. Elsewhere, where knowledge and physical objects were still in place, a stratum of tradition bearers, a generation that had direct knowledge was still around, we can in fact talk about a kind of continuity. By this time, the renewed revival village costume is worn on special occasions. It could be worn by both young people who had never worn costume and older people who had once worn it regularly. The meaning and emotional content of the local costume and the occasions of using the costume may have been different for them, of course. The use of the revival costume as festive attire is typical. Aesthetic considerations have come to the fore, which, among other things, explains the preference for former festive costumes. Prestige can also play a role in revival.

\section{A case study for the revival of the costume}

In Sióagárd (Tolna county) "re-costuming" began in the second half of the 1970s. From the age of four, as they grew, girls were constantly provided with new outfits. An older, adolescent girl may have had a serious wardrobe, depending on the financial means of her family. "Where there's a girl, you have to get it," they said. ${ }^{102}$ In the second half of the 1980s, the girls and young women of Sióagárd wore their costumes willingly for major church holidays and harvest balls. (Figure 34, 35) The older women who had abandoned the costume in the 1960s also re-acquired 2-3 or even 10-15 sets of "get-up" (costume ensembles), depending on their capabilities. "We didn't go abroad, we put our money into this." People between the ages of 40 and 60 were also more likely to wear costume on regular Sundays, weddings, and gatherings. Their use of costume was better suited to the occasion than that of young people. But at the same time, it was surprisingly random whether they went to church on Sunday in costume or in city clothes, as their mood dictated, because both solutions were accepted here. One of my informants said, for example, that if she had a good hair day, she would choose city clothes, if not, she'd rather cover it with a scarf and wear costume.

The occasional wearing of folk costume by the elderly is encouraged in some places (including Sióagárd) by the costume having an advertising function. (I'm not referring here to tourist advertising, although that could be the case, too.) Women in some marketeering villages go to the weekly market in costume and wear costume as a trademark of their goods. I have heard of a woman from Sióagárd who otherwise wore city clothes but always put on a costume when going to the market. In Bag they say: "We went to the market in nice clothes." In the markets of Pest, the tomatoes from Fót were the most famous. There was a woman from Szada who bought herself some clothes from Fót for marketeering, just to be able to sell her tomatoes better. (Figure 28)

In Sióagárd, the revived costume had a remarkably high emotional content, both among young and older people. Several factors seem to contribute to the success of the costume revival in Sióagárd:

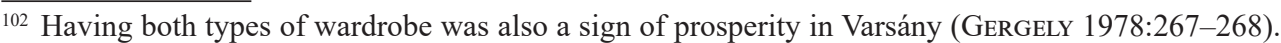
JÁVOR 1978:307 points out that aspects of prestige also played a role in the popularity of the dress of the 'Maidens of Mary' in Varsány, which was worn during Catholic church processions. 
- the strong emotional attachment to the dress may have been due to the fact that the village has a nationally recognized and sought-after "famous" embroidery and costume;

- in general, the fact that the typically local, heavily "peasant" costume is the result of a very late development (the interwar period, but essentially the existence of an adaptive costume system evolving until the 1960s);

- the competitive, determined mentality of the people of Sióagárd focused on material prosperity, which stems from the historical experience and adaptation strategy of the former settlers of the checkerboard village re-established in the 18th century (after the destruction of the Ottoman occupation);

- the material prosperity in the 1970 s of a village in the immediate vicinity of the county seat, Szekszárd, with good soil conditions and vineyards, jobs, and a well-functioning agricultural cooperative, specializing in vegetable and fruit production;

- the intensity of prestige competition resulting from the above;

- religious life (Catholic), remarkably active even in the 1980s;

- even at the time of the study, the community was conspicuously "closed," cohesive (which, of course, is a relative concept), with a number of well-functioning traditional community events;

- the fortunate confluence of the external encouragement of the revival and their pre-existing willingness.

The process was initiated by the Village Days organized in 1968 and the campaign that preceded it. The costume was first revived for the Village Days as a pageant dress. The Fly Peacock Movement and the dance ensemble, which has been operating continuously since the early 1970s and built in part on its Gyöngyösbokréta past, provided additional impetus to the revival of costume and local traditions. At the time of the study, not only the costume culture but also the embroidery culture was very active in the village, capable of constant renewal and adapting to new functions. ${ }^{103}$

The above example of Sióagárd well illustrates the remarkable role of the local church parish, which in many places encouraged the cultivation of traditions. In several villages, the intensive revival was initiated or supported by the church, giving it a framework and an opportunity to present itself on certain occasions (Bogyiszló, Zsámbok, Varsány, Sióagárd). In general, there seems to be an obvious correlation between the activity of community life, the intensity of costume revival, and the activity of religious life. The church, which has always been a place to show off one's costume, still offers a natural, spontaneous occasion to wear it. (Figure 34-37)

Summarizing the occasions of the use of costume by young people around 1988, we can group them as follows:

${ }^{103}$ Aunt Kati Mancsi was the most famous writing woman, innovative personality of the village (born in 1905 and still active in 1987). Her name was associated with the first embroidering of the bodice in the 1920s and the first floral embroidering of silk aprons in the 1960s. She introduced newer and newer colors and motifs. Her activities practically not only accompanied but also shaped the late $20^{\text {th }}$ century high period of the costume and embroidery of Sióagárd. Adapting to modern needs, in the 1970s and 80s she "wrote" or embroidered table runners and pillows for modern Varia furniture (wardrobe, coffee table, armchair), and the framed embroidery tapestry and embroidery tray (glass tray with wooden frame, embroidery under the glass) was her "invention." 
Traditional occasions: (these can also arise spontaneously according to the internal needs of the community, when they can actually wear the costume in its traditional function): wedding (new bride's outfit, best man, guests), first communion, confirmation, 'Maidens of Mary' on major church holidays (Figure 37), costumed altar boys, mass on Sundays and holidays, harvest ball.

The custom of the harvest parade and ball is worth exploring in more detail. In the studied villages, the custom began in the first half of the 1920s, by a top-down initiative, led by the local intelligentsia, clerks, teachers, levente instructors, and mostly with the participation of some youth groups (levente youth organization, bachelors' club). The custom was practiced until the 1950 s and 60 s in various ways. After a long break, it was revived in the 1970s, also thanks to an outside influence, and led by local dance ensembles, educational institutions, official bodies (in Varsány, for example, it was organized by members of the Communist Youth Association). In the second half of the 1980 s, there were different levels of activity in the practice of the custom:

- In some villages it was an organic, spontaneous, communal event that engaged the entire village.

- There were places where it was a performance-like production of the local ensemble or school/kindergarten groups.

- In some villages, but especially in cities, it was a more contrived tourist attraction.

- In its final form, it was a simple dance party heavily stripped of the usual customs. Looking at the costume part of the harvest parade custom, three types of clothing emerge:

- The former local costume, or one that is still "alive" in some form.

- An adapted local costume, which has been updated with certain elements, making it "Hungarian." (In Bag they wear a white apron and a bodice decorated with a national tricolor ribbon.)

- The so-called Hungarian dress (see explanation later). (Figure 39)

Non-traditional occasions: (In these cases, there is no spontaneity, they are organized, often "social events." The folk costume is already treated here as a memento or curiosity, its wearing is more of a "fancy dress".

- a "social event" organized by local official bodies, to which performers are invited. (There are a number of stories about the intelligentsia and local leaders of the villages readily showcasing the costume as a local specialty in the past.)

- school ceremony,

- kindergarten, school carnival ball,

- stage costume for dance ensembles and folk singing circles

- tourist attractions, e.g., featured wedding.

Where there is a lively costume tradition, the costumes of the local ensembles are also more lively, more authentic, appearing in several versions (e.g., Kazár). (Figure 38) Where the costume has been "uniformized" or has long since disappeared, the revived costume is but a stereotyped, often inaccurate, weak echo of the costume that once was (in Madocsa, for example, the ensemble's costume, which was supposed to be a reconstruction of the original, turned out much more "peasant" than the original ever was). The final stage is when the paraphernalia of traditional wear has been destroyed a couple of generations prior, and hardly any knowledge about it remains. These are the places where "Hungarian dress" may show up as a fancy dress (at a harvest ball, costume ball), as a kind of memento of their former peasantness (Madocsa). 
The so-called Hungarian dress: was an attempt at creating a romanticized national costume that simultaneously evoked and trivialized the features of traditional "ceremonial Hungarian noble gala dress" and peasant dress, utilizing a simple color scheme based on the tricolor national flag. The Hungarian dress worn by girls and ladies featured a red and white headdress, laced bodice, skirt, apron, and red boots. Its male counterpart was a loose-sleeved shirt with a frogged waistcoat, linen trousers or breeches, and boots, reminiscent of the garb worn by peasants and herdsmen in the $19^{\text {th }}$ century. Popular musical theater productions and harvest parades initiated by the aristocracy at the end of the $19^{\text {th }}$ century both contributed to its growing popularity. As a simplified, syncretistic product, Hungarian dress might even be considered vulgar kitsch, but it was based on a broad public consensus and was therefore worn by the widest segment of society. It was also adapted by the elite and middle-class for use in ballrooms and amateur theater productions and tableaux vivants. As a sartorial expression of national sentiments, it increasingly began to appear after the trauma of Trianon at village harvest festivals, school celebrations, and public events. Cliché figures clad in Hungarian dress have also appeared in numerous areas of popular culture (from press illustrations and other printed materials to movie costumes, chinaware figures, dolls, and products of the tourist industry). In certain regions where modernization affected rural communities early on (around the turn of the $20^{\text {th }}$ century), it even served as festive attire, reflecting the former peasant character of the community. In fact, even the most conservative regions with distinctive folk costume traditions were unable to avoid its stereotypical impact, and sometimes entire sets or individual elements of "Hungarian dress" were adapted to local traditional attire for special occasions. Because of its obvious power to express ethnic/ national identity, Hungarian dress has remained popular among Hungarian immigrants in the West until recently, including the display of mementos (prints, porcelain figurines, dolls, etc.) in private and community spaces. Among Hungarian-Americans who grew up before the dance house movement of the 1970s, their image of the old country and its folk art continues to be dominated by vulgar stereotypes of Hungarian dress (BALOGH 2010). ${ }^{104}$ (Figure 40, 41)

Edit Fél and Tamás Hofer call the Hungarian dress of the Kolozsvár-Hóstát ${ }^{105}$ harvest ball, purchased for the textile collection of the Museum of Ethnography, "secondary, late attire." They justified its acquisition as follows: "it documents the national process of urbanization - like a document of the popular illusions that emerged among the peasantry at the time of the disintegration of the old village way of life," "closing down a series of costume trends dating back to the past, illustrating the last stage of costumes with a long history, when certain newly fashionable customs, such as harvest balls, which spread independently of viticulture, were given a slim chance at life as symbols of the bygone peasant era" (FÉL - HOFER 1970:140).

${ }^{104}$ An analysis of a 1987 harvest ball of a Calvinist church congregation near Chicago illustrates how the practice of the harvest ball and the Hungarian dress or other folk costumes worn there express the ethnic identity of American Hungarians (FEJős 1987).

${ }^{105}$ Hóstát is a district in the Eastern part of Kolozsvár/Clausenburg/Cluj, part of a former ring of garden villages outside the medieval city walls, where burgher-peasants specialized in farming and produced food for the city. 


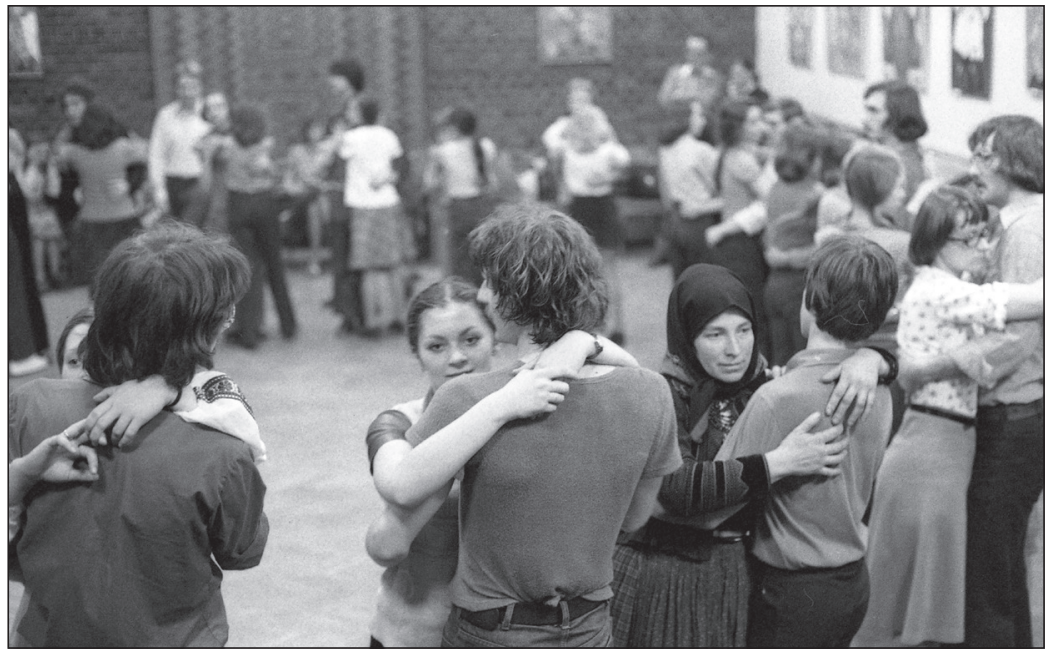

Figure 31. The dance house of the Sebö ensemble in the Kassák Club, Budapest, 1976. Costumed guests from the Transylvanian Szék teach the Széki slow csárdás to live music. (Photo: Fortepan: 88685, donor: Tamás Urbán, downloaded Aug 10, 2020, http://www.fortepan.hu/_photo/download/fortepan_88685.jpg?rand=1597611489)

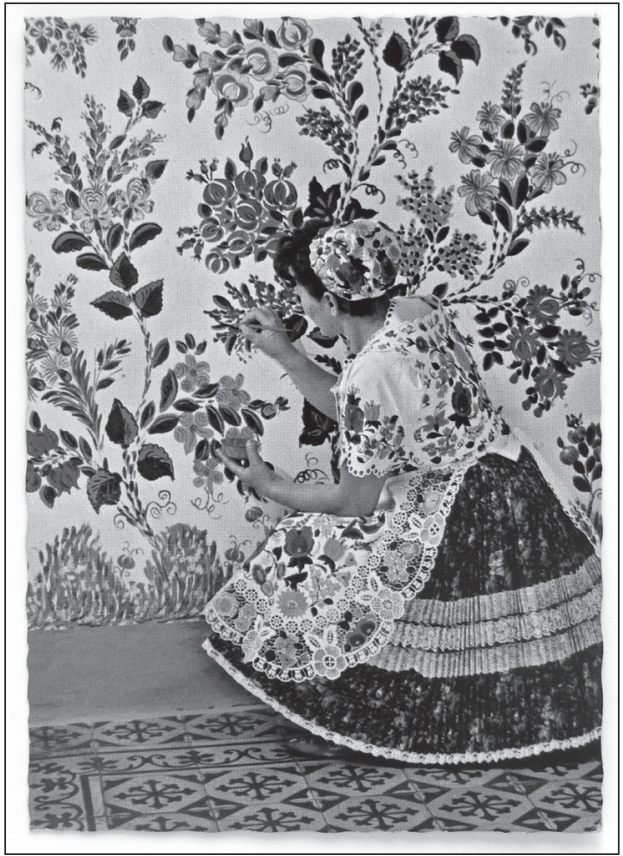

Figure 32. A popular postcard from the 1970s, depicting a wall-painter woman (pingáló) from Kalocsa in folk costume. (Photo by Károly Gink, Budapest: Képzőművészeti Alap Kiadóvállalata)

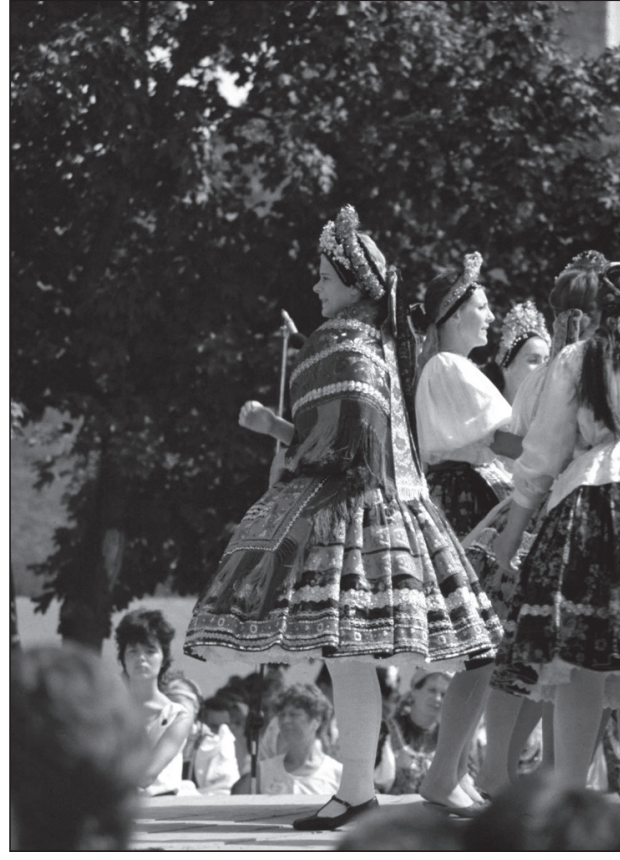

Figure 33. The dressing of the bride on stage during the so-called Sárközi wedding annual festival. Decs (Tolna county) 1987. (Photo: Ágnes Fülemile) 


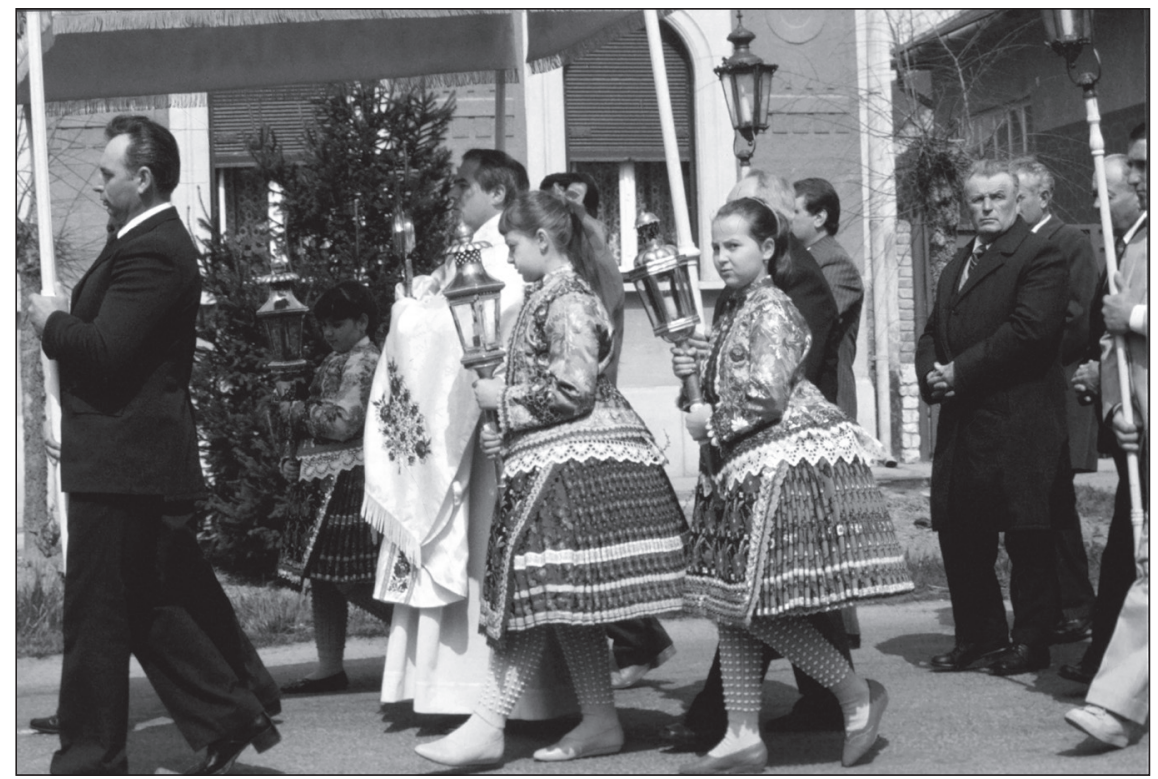

Figure 34. Easter procession. Sióagárd (Tolna county) 1987. (Photo Ágnes Fülemile)

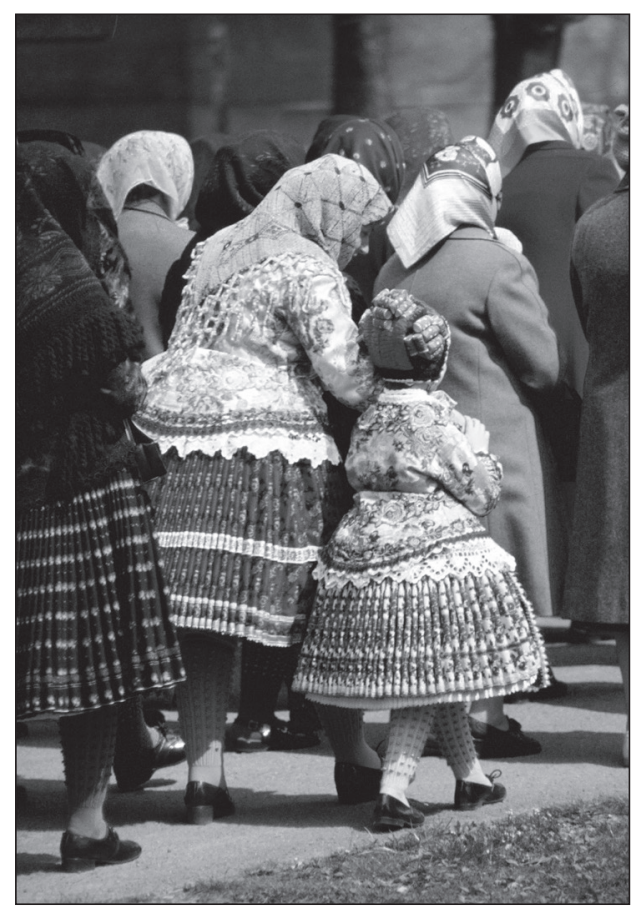

Figure 35. Young mother and daughter in the Easter procession. Sióagárd (Tolna county) 1987. (Photo Ágnes Fülemile)

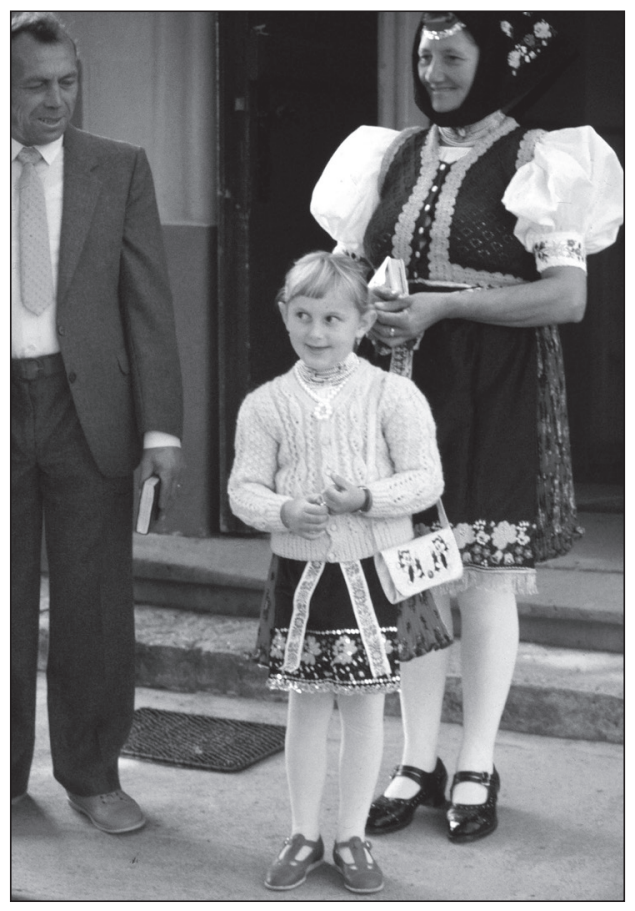

Figure 36. Grandparents with grandchild in the St. Michael's Day procession. Varsány (Nógrád county) in 1987. (Photo: Ágnes Fülemile) 


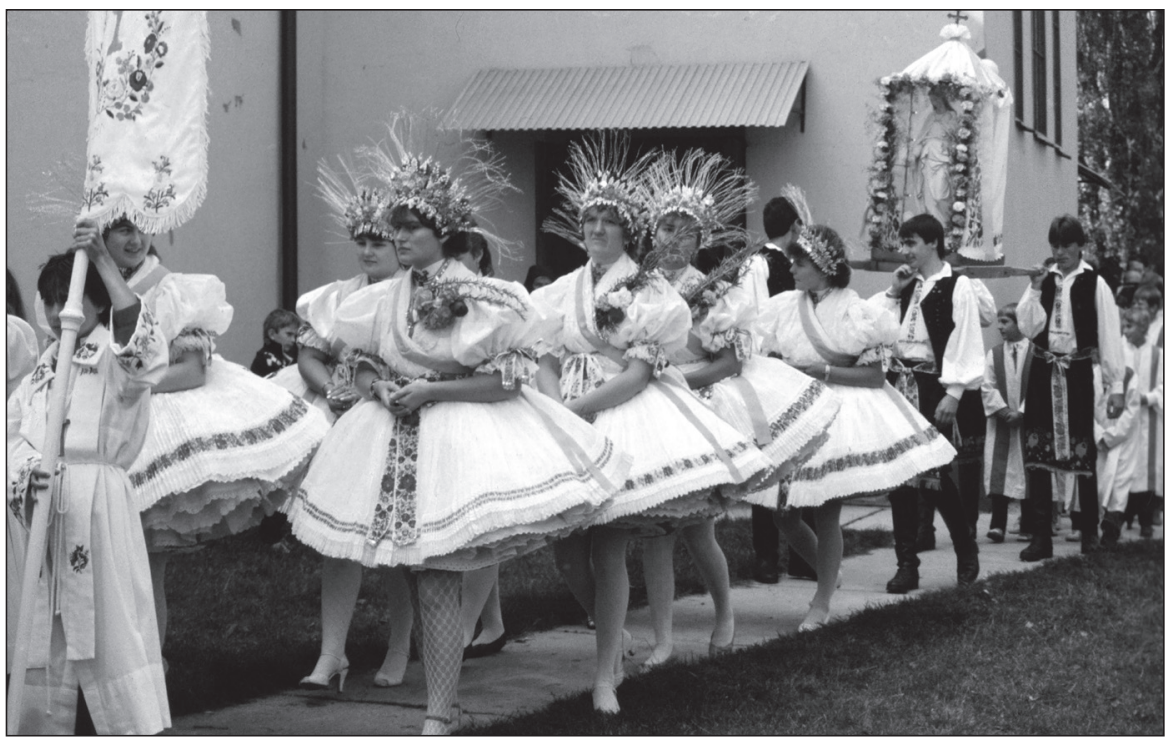

Figure 37. 'Maidens of Mary' in the local (bridal) costume enhanced with a light blue ribbon (blue being an attribute of Our Lady) in the St. Michael's Day procession. Varsány (Nógrád county), 1987. (Photo: Ágnes Fülemile)

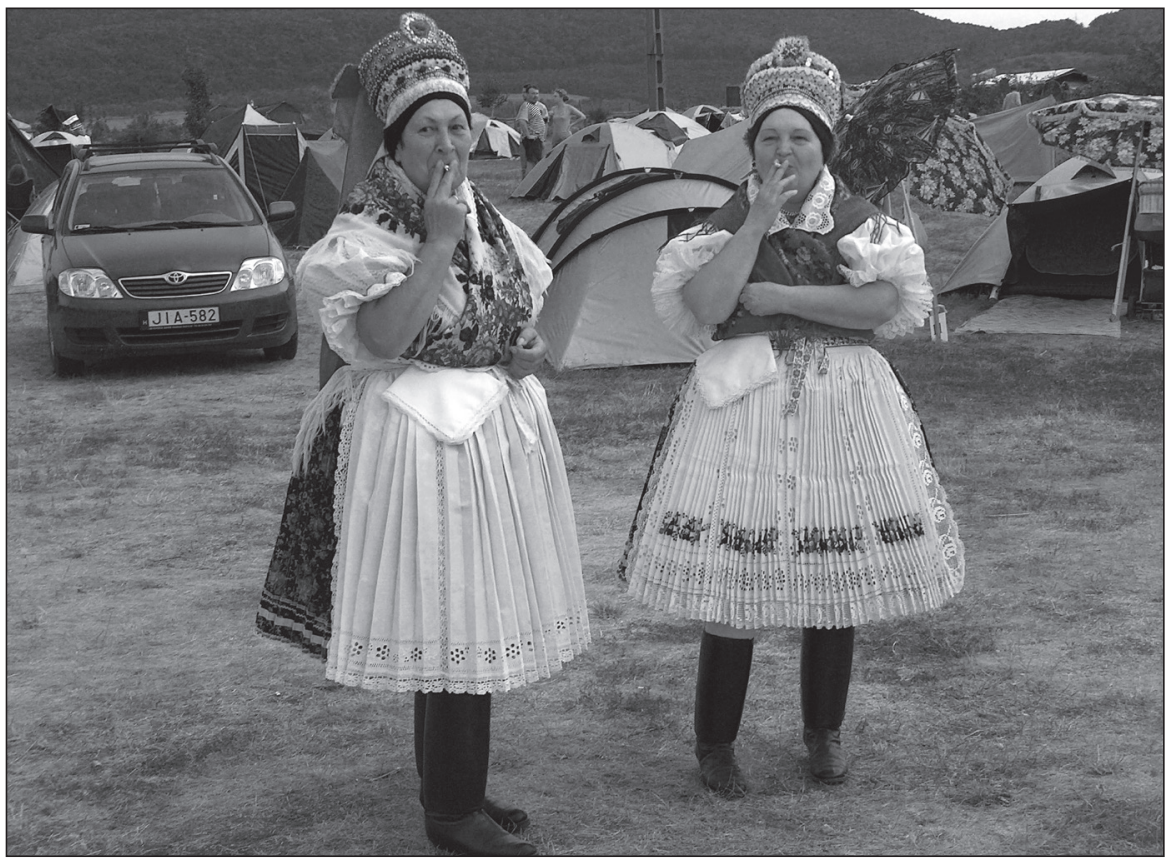

Figure 38. Members of the traditional dance ensemble of Kazár before performing at a festival in 2006. The women in the picture have never worn costume, but the ensemble's stage costume is original in terms of both costume and ways of putting it on. (Photo: Ágnes Fülemile) 


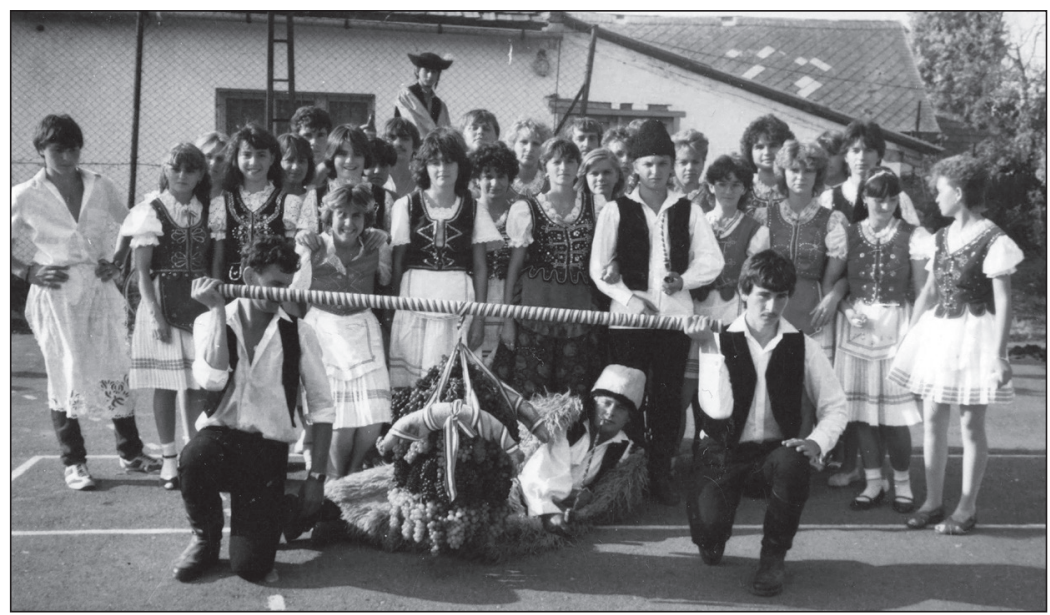

Figure 39. Young people in Hungarian clothes at the harvest ball in Madocsa in the mid-1980s. (Tolna County) (Photo privately owned)

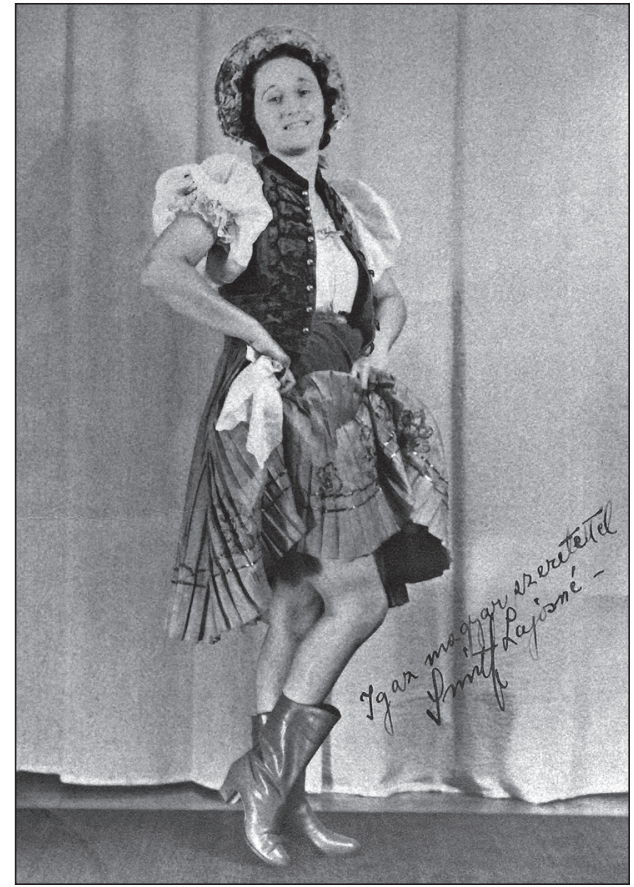

Figure 40. Photo of a Hungarian-American woman in a Hungarian dress from the 1950s, with her inscription "With true Hungarian love...", Archive of the Reformed Presbyterian Bethlen Retirement Home in Ligonier, PA. (Photo: Balázs Balogh, 2008)

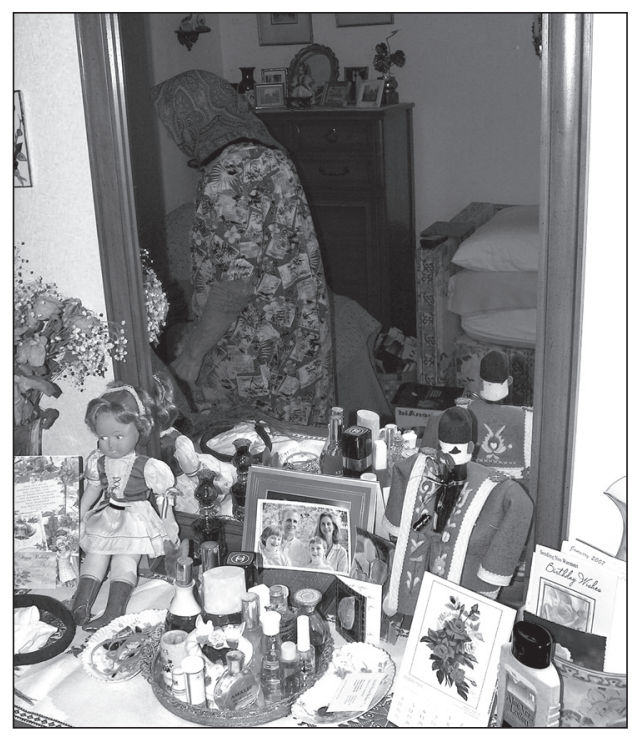

Figure 41. An elderly resident of the Bethlen Retirement Home (Ligonier, Pennsylvania) in 2008. She came from a family of poor peasants and was young when she left Hungary after 1956. Family photos, postcards, Hungarian souvenirs and a doll in Hungarian dress in front of her mirror. As seen in the mirror, the woman still prefers to wear a housecoat and headscarf at home, like many elderly women of her age in the countryside in Hungary. (Photo: Balázs Balogh, 2008.) 


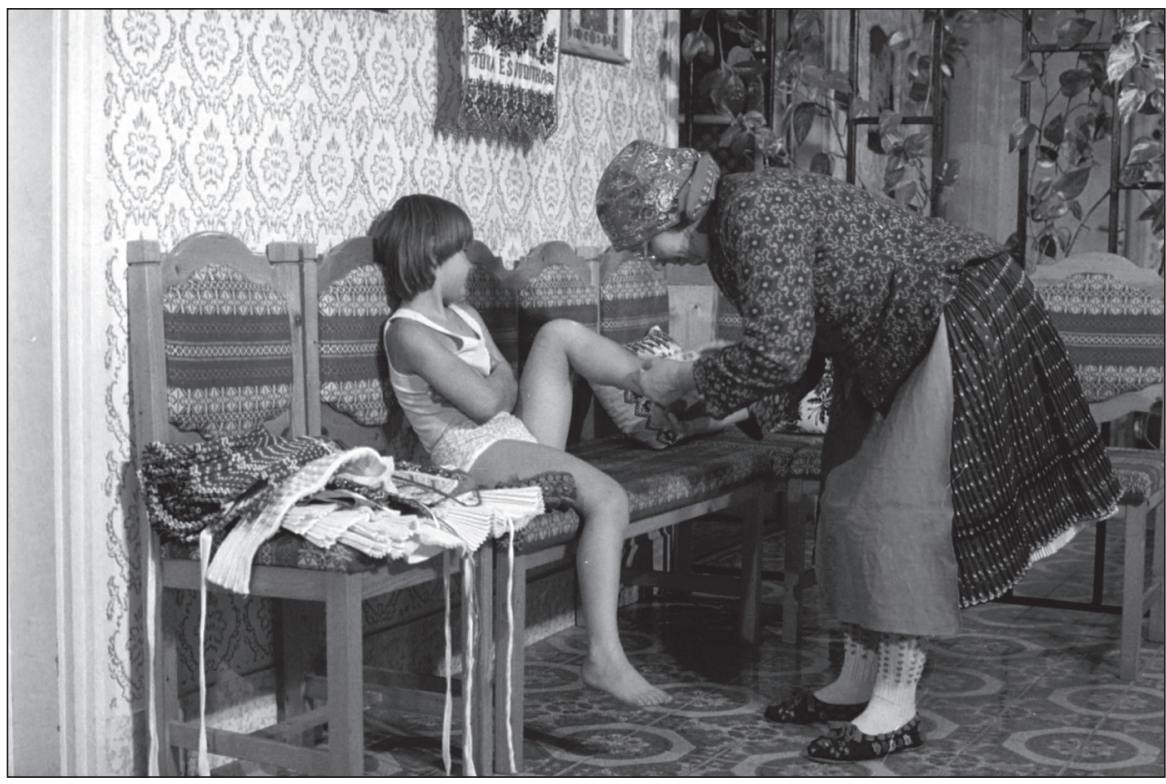

Figure 42. Costuming a grandchild for photographing. Sióagárd, mid-1980s. (Photo Collection of Museum of Ethnography, Budapest inventory number: D 17031)

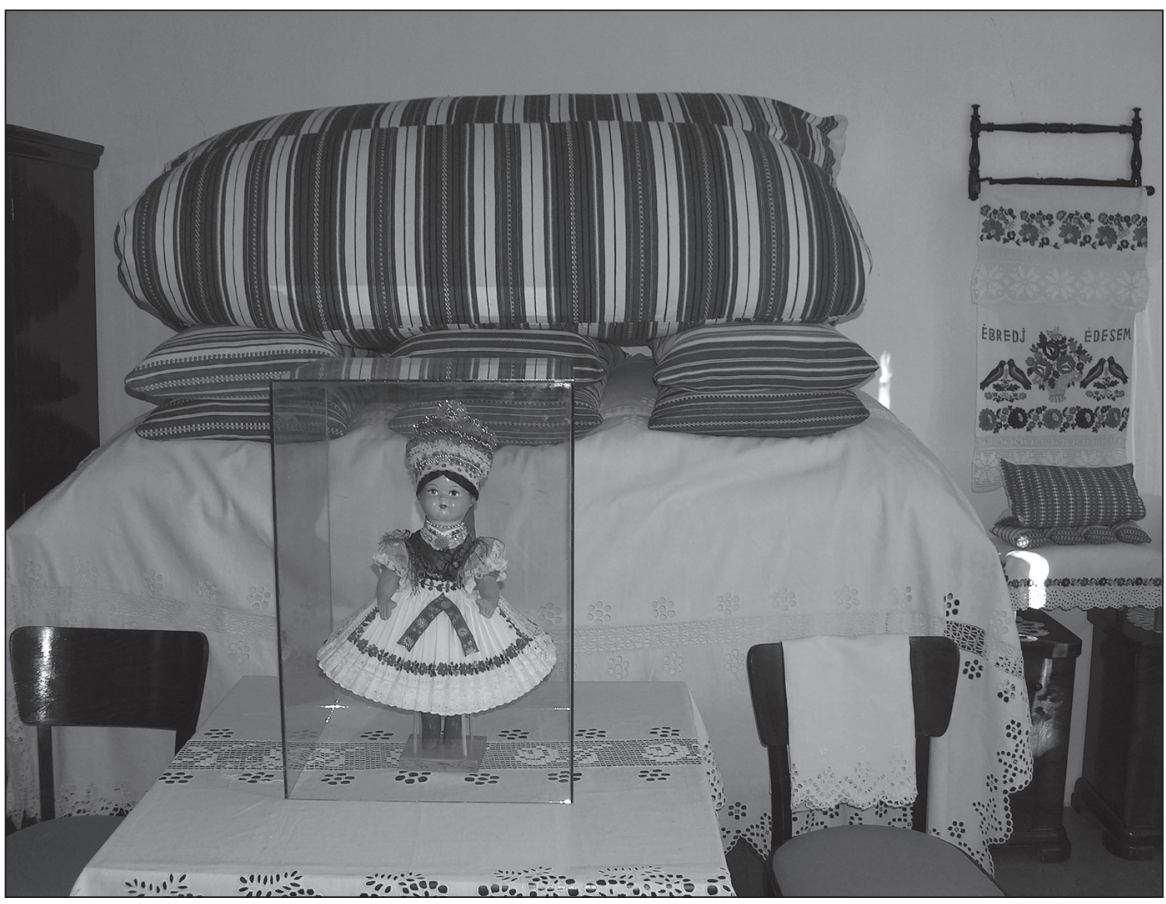

Figure 43. Clean room of a costumed woman with a doll from Kazár, 2002. Kazár (Nógrád county) (Photo: Ágnes Fülemile) 


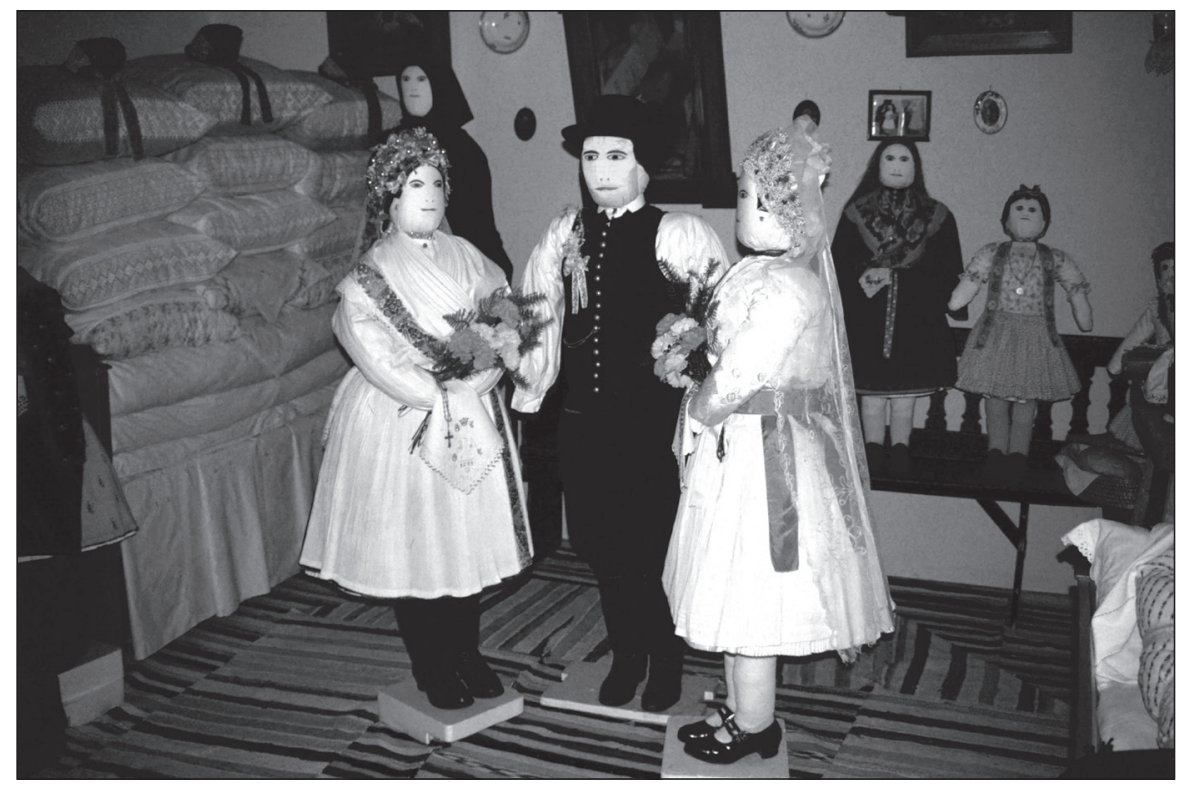

Figure 44. Ways of remembering: Aunt Bözsi's doll museum of her own creations. Bag (Pest county), 1987. (Photo: Ágnes Fülemile)

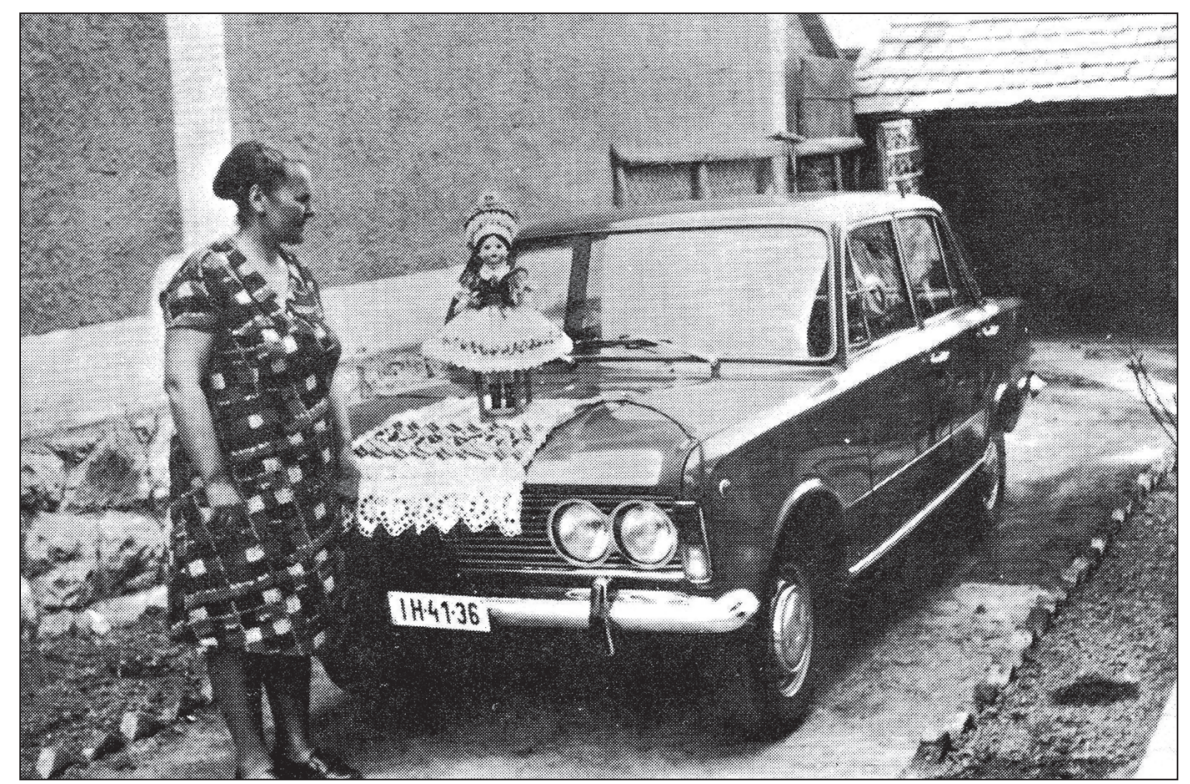

Figure 45. Symbols: new car and doll from Kazár on a photo taken by the family in the mid 1970s. The car is the Soviet made Zhiguli 1500, the luxury dream car of the socialist camp, a true status symbol. The doll on the top of the new acquisition has symbolic significance for the woman who abandoned her costume in the 1960s. Kazár (Nógrád county) (Photo privately owned) 


\section{Practices of remembrance:}

Preservation or memoralization of heritage through recurrent practices and memorabilia plays a major role not only in the life of the community but also in the life of the family and individual. Revived folk costume has a great emotional value in many places. Framed photos of costumed children and family members are prized decorations of homes. Grandmothers would sew an outfit for their grandchildren, and they would set aside an outfit and some woven goods, "in case she'll need it later," "maybe she won't throw it away." (Figure 42)

One way to preserve memories is to make dolls dressed in folk costume. The dolls dazzle in the most festive outfits, as do members of dance ensembles or costumed children. I have encountered "doll dressing" as a phenomenon accompanying the late "fancy dress-like stage" of traditional costume in every community that was once "famous" for its folk costume.

There are data on the gifting of dolls in folk costume from the 1930s. In Kazár, some women began making dolls at the encouragement of the local intelligentsia and landowners. The clerk, the priest, the landowner liked gifting their guests with these dolls as a local curiosity. At the St. Stephen's Day celebration in 1931, the gyöngyösbokrétás group from Boldog gave Budapest Mayor Ferenc Ripka a costumed doll from Boldog (ÚJváRY 1981:10). Upon his visit to Budapest in 1958, the Nikita Khrushchev, the first secretary of the CPSU (Communist Party of the Soviet Union), was gifted a doll from Kazár. Making dolls has several purposes. There are specialists for making dolls (doll-makers), but many also make them themselves, to meet the demands of their own environment or to make money. Doll-makers work mainly on ecclesiastic or social commission, or to serve tourist interests. The doll-maker of Galgaguta, for example, is often commissioned by the church and the council, and her dolls are considered a popular repi-ajándék (swag). ${ }^{106}$ János Kádár, for example, received a doll from Galgaguta during his visit to Nógrád. The examples could be listed at length. The villagers often give it as a thank-you gift to doctors, or to young relatives. The dolls are also being incorporated into wedding customs in several places. In Tura, the groom has been redeeming the bride from the bridal dance with a doll since around 1970. In Galgaguta, the young couple receives the doll as a wedding present, which is then displayed in a place of honor throughout the wedding. ${ }^{107}$

Doll-making nonetheless has a much more important reason. Doll-making serves as a kind of supplementary activity for the elderly generation still wearing costume and not being able to pass on their knowledge. For them and their contemporaries who abandoned folk costume, the doll is a memento and image of their former selves. "Look here, I'm making a doll for myself," said a woman from Bag who abandoned her costume, "so at least I would have this. So that I can show how we used to be." Edit Fél writes in connection with the "un-dressed" Matyós: "they want to make a doll from their remaining clothes - a portrait of their former selves, as a memento...” (FÉL 1952:73). The meaning of the doll expanded beyond individual and generational remembrance and during the examined period came to provide the entire community a means to express

\footnotetext{
${ }^{106}$ I purposefully used the term repi-ajándék (swag) here, an epithet characteristic of Hungarian socialism. In effect, it is a representative/promotional gift.

${ }^{107}$ Until 1960, before the doll, the customary redemption for a bride in Tura was an apple, later a teddy bear.
} 
"the way we were". It was a prized ornament in every household, for young and old alike. The doll, dressed in local attire, became an identifying symbol, a proof and symbol of belonging to the community. ${ }^{108}$ (Figure 43, 45)

The multiple ethnic doll collections in the USA (i.e., NYC Museum, Brooklyn Museum), or the concept of Small World at Disneyland, ${ }^{109}$ illustrate that ethnic communities from all over the world have expressed the memory of their self-entity as viewed nostalgically in their relationship to "tradition" in similar ways.

\section{CONCLUSIONS}

There are a handful of examples of rural communities in Hungary - the last enclaves where the interwar period brought the most elaborate period of the traditional clothing system. In these places, the abandonment of peasant costume and a switch to urban style took place only between the 1950 s and 1980s. It was primarily the female costume that was preserved for a long time, with a split gender ideal between tradition represented by the women and modernity by the men. In these communities, the logic of the liminal period of change was as follows:

The urbanization of peasant dress was not a smooth, unaware, step-by-step process of accepting and mixing elements of urban fashions with the "traditional" system. Members of the first generation to have switched to urban fashion recalled the decision to change as a big challenge and the "grand event" of their lives. It required strategic preparation; they collected an entire wardrobe of fashionable dress (still thinking in terms of the dowry) before switching to urban with a demonstrative appearance, after which they did not mix elements of traditional and urban. They interpreted the act as the start of a "new life". The systematic character of the change was illustrated by the fact that they had their hair cut, practiced how to move in urban dress, started following a more flexible decorum, and even switched the style of home furnishings and household textiles alongside the dress. Although they tried to be as radical as possible, a communal uniformity still characterized this generation, with a preference for the same solutions in details. The inclination toward certain colors and patterns remained the same as before. As they aged, they often returned to the longer hair, and all of them wore a bun of the very same style. This first generation of changers stayed

\footnotetext{
${ }^{108}$ There are many examples for the use of costume-related expressions, including costumed dolls as an ethnic symbol. The symbolic meaning can be especially demonstrative in ethnic minority and diaspora situations. The custom of acquiring/making and displaying dolls is also prevalent among American Hungarians. The doll, logically dressed in Hungarian dress and considered a "valued ornament of Hungarian homes," is interpreted as an "ethnic symbol" (FeJős 1987:278). (Numerous articles on the articulation of ethnic symbols have been published. I do not consider it necessary to review the relevant ethnographic literature here.)

${ }^{109}$ In the 1980s-1990s at "It is a Small World (after All)" Disneyland in Los Angeles (a classic Disney boat ride around the globe showcasing animatronic dancing dolls in traditional costumes, originally created for the 1964-1965 New York World's Fair, personally overseen by Walt Disney in support of UNICEF and shipped to and operating in Disneyland since 1966), an accurately dressed life-sized doll from Kazár was displayed among the other Eastern European displays. Knowing the original Kazár costume, I was surprised to experience and acknowledge the authenticity of the display.
} 
emotionally close to what they had left behind and looked back with nostalgia to the memory of their life in traditional costume.

After the process of abandonment had accelerated, a part of women's society decided to change while others remained in costume for the rest of their lifetime. A generational gap developed in this period within the locality. After this split, the subsequent younger generations dressed the urban way. Real fashion sensibility developed only in later young generations.

For the aging and decreasing community of women still in traditional dress - also serving as controllers of norms - the relaxation did not mean the complete erasure of rules. Though certain rules of the sartorial system underwent a restructuring, the systematic character of the clothing order remained functioning. The age limit for using youthful colors and embellishments remained in effect for another 10-20 years. Festive materials were used more and more for everyday occasions, seeing that they were stuck with the abundance of their wardrobe and there was no need to pass on these articles to younger members of the family.

The peasant dress, which was once an important matter for the entire community, became a means of self-expression for a limited group of a few tradition-conscious individuals. Behind their decision are several factors: social position (often middle peasant "conservativism"); family attitudes; personality traits; an inclination to identify with certain public role models. Among the last to preserve traditional costume and "steward" heritage were often women of poor peasant origins who had no economic opportunities previously to obtain a prestigious wardrobe. In the period of fashion change, they accomplished their "lifelong dream" by collecting traditional pieces and displaying the abandoned style with an anachronistic gesture of prestige representation.

The last generation's emotional attachment to the preservation of dress and the rigorous awareness of how they experienced and remembered every important station of change as a loss of value was remarkable. Their prophetic prognosis of tradition was summed up in their narratives: "When we die, the youngsters will throw everything onto a bonfire. The fire will consume everything we lived for all our lives."

Members of that particular generation ("pioneers" and "guardians") started to come up with alternative ways of nourishing their psychological need for passing down knowledge and values (thus validating their own life "achievements"). They would prepare at least one set of costume for their grandchildren to have them photographed in, and then exhibit the framed photo in a representative space of the home. They made and gifted dolls dressed in local costume (from the pieces of their own dress) to young family members. The proof that the message was received by the larger community is in the consensus that the costumed doll became a valued gift - and even representative guests (often state and party leaders on official visits) received these folkloristic gifts -, and furthermore it has been commercialized as a well marketable tourist attraction. Making dolls, a "miniaturized" copy, a "relic of themselves," became the most important channel of the nostalgic expression of heritage remembrance in this late phase of the disintegration within Hungary and beyond, in emigrant communities as well.

Highlighting the motivations behind the decisions of that very generation of young women who had to choose between abandoning or retaining their local peasant dress reveals that there was a high level of self-awareness and strong emotional attachment in individual relationships to clothing in the rural context, similar to - or perhaps even exceeding - a fashion-conscious, individualized urban context. 


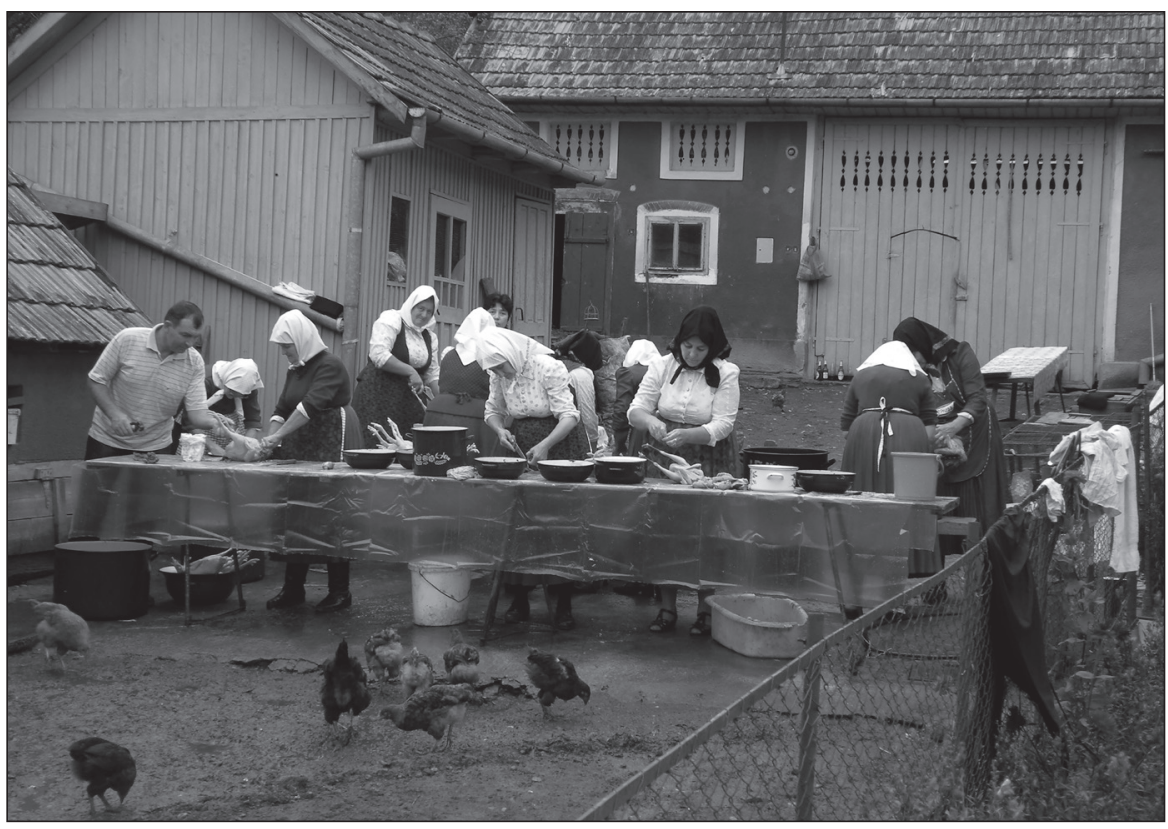

Figure 46. Plucking chicken for the wedding soup. Szék (Sic, Transylvania, Romania). Middleaged women wearing costume, a good portion of whom work as cleaning ladies in Budapest. They returned home to help with the wedding preparations. 2008. (Photo: Ágnes Fülemile)

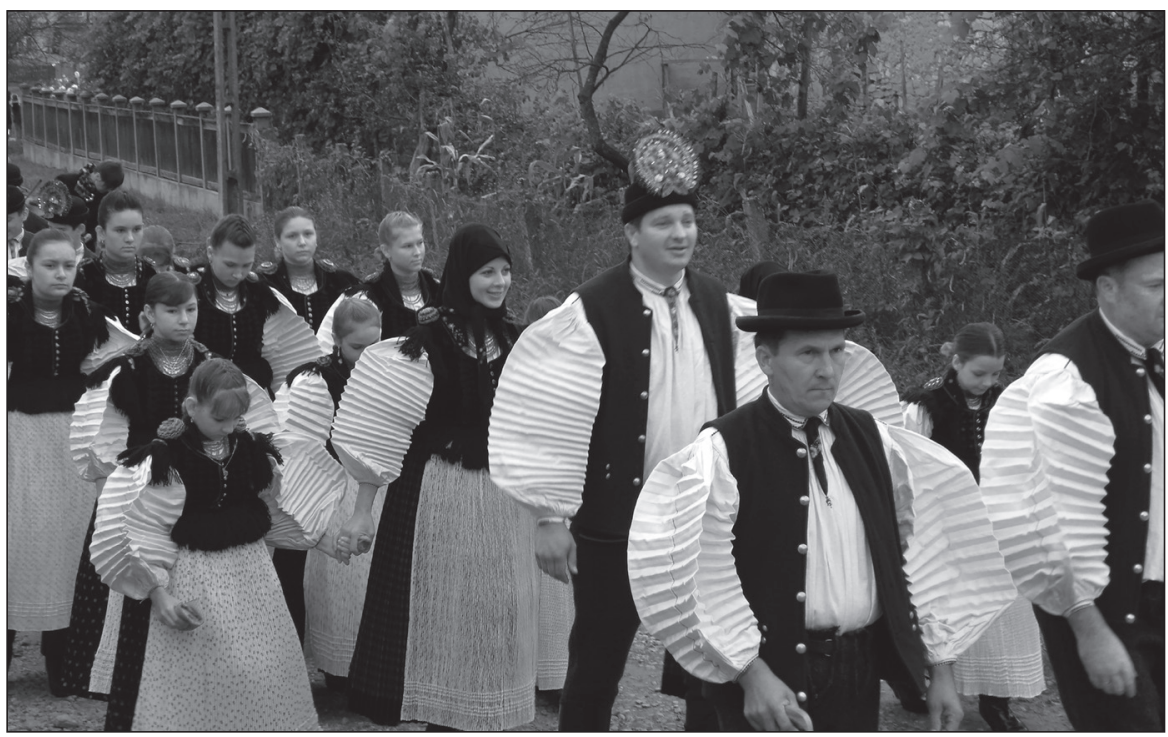

Figure 47. The wedding procession with the groom, on their way to the bridal house in Szék (Sic, Transylvania, Romania) in 2008. The discovery of the rich traditions of the settlement in the 1970s was a revelation, becoming a model and starting point for the dance house movement. (Photo: Ágnes Fülemile) 


\section{EPILOGUE}

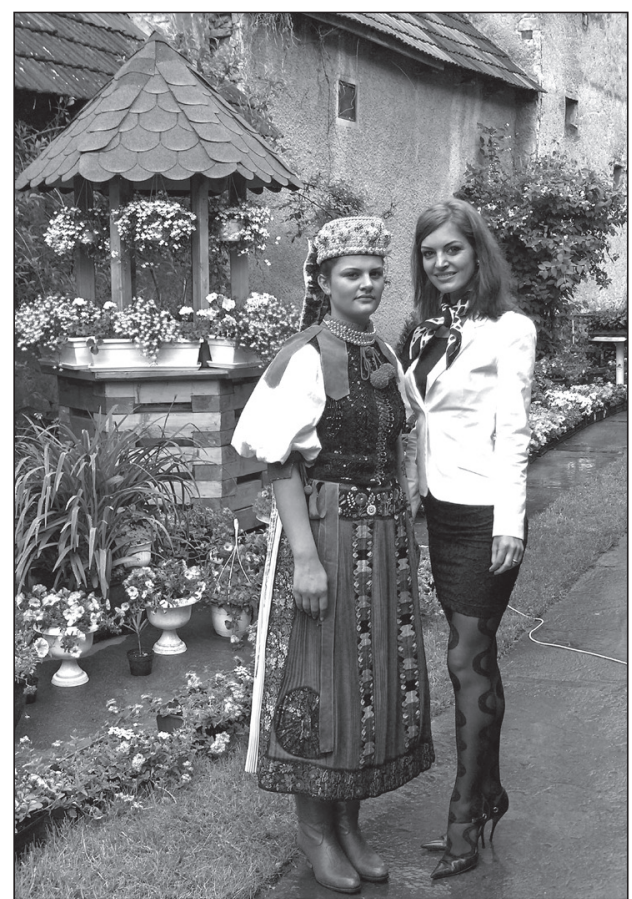

Figure 48. Candidate for Reformed Presbyterian confirmation and her older sister at the postconfirmation family feast in Bánffyhunyad, 2005, (Kalotaszeg, Transylvania, Romania), (Photo: Balázs Balogh)
Traditional attire has become a rarity in Hungary. Some 20-30 years ago, it was common to see women in multiple layers of peasant skirts in the vicinity of larger markets in Budapest or along the suburban train lines, commuting from the "garden" villages surrounding the capital, i.e., the Galga river valley. Nowadays we seldom see them anymore. Today, 30 years later, the last of those who still grew up in traditional dress are leaving us. ${ }^{110}$

Some minority regions or communities outside Hungary, especially in Transylvania (Romania) experienced an even more delayed period of disintegration, where the process of change accelerated only in the 1990s and the first decade of the 2000s. The harsh anti-minority practices of the Ceauşescu era in Romania (until its fall in 1989) and the eruption of suppressed emotions in its aftermath in the 1990s strengthened the manifestation of ethnic minority identity through traditional dress as a community marker. The main community institutions, the church and the school, which also call for the preservation of traditions, remain important public spaces for local minority public life. Minority institutions, municipalities, and cultural organizations also help with carrying on or inventing events and ceremonies where ethnic dress is displayed. The new meanings, expressed through the public wearing of regional dress and the current ongoing practices of 'festivalization' and 'heritagization' helps prolong its preservation. (Figure 48, 49)

In many cases, family and community rites of passage are accompanied by a system of customs that is more nuanced than the one in Hungary, in which a set of traditional clothes still plays an important symbolic role. (Figure 47, 48) Surprisingly, in the first decade of the $21^{\text {st }}$ century, in the last few rare "islands of tradition," the dual parallel of the modern and traditional dowry may still have a great prestige value,

${ }^{110}$ Such as Aunt Panni, my main source and host in Kazár, whom we had to bid farewell to in February 2010. At the time of her funeral, only four among the approximately 100 women who once represented her community of women in traditional dress during the 1980s were still alive, and only one would still venture out into the streets. No longer are there occasions in Kazár to wear traditional dress in its original function; only members of the local folk dance ensemble and the heritage preservation group wear costume for local events, stage performances, and festivals. 


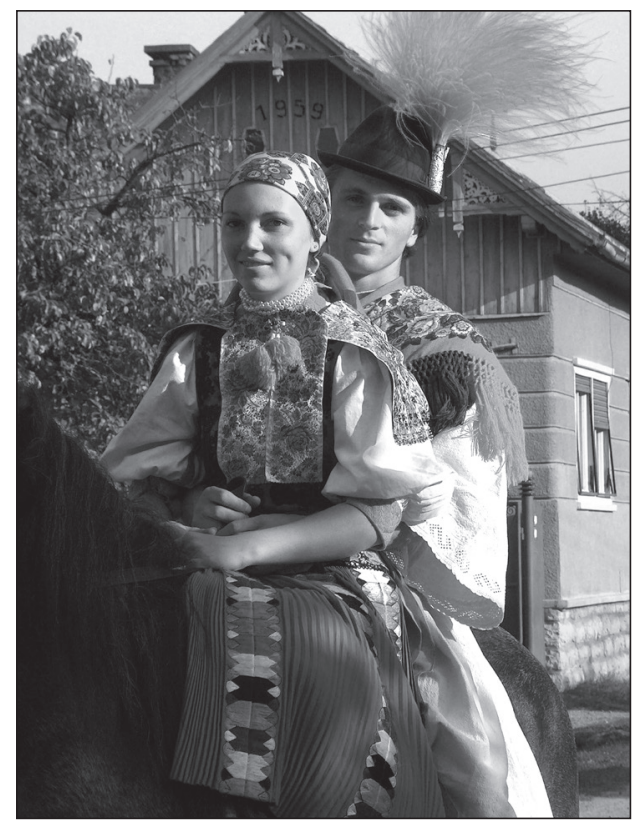

Figure 49. Hayward couple at the harvest parade in Kalotaszentkirály, 2006. (Kalotaszeg, Transylvania, Romania), (Photo: Ágnes Fülemile) and the traditional dowry has, in fact, had a very competitive monetary value. People may spend unrealistic fortunes on certain prestigious pieces of old garments $(\$ 1,000$ 2,000 for a set) if they need a costume for a first communion or wedding. Mere emotional value would not explain this without the prolonged role of the dress in the prestige competition within these rather well-to-do communities. The new meanings and functions of ethnic dress seem to lie in another, more pragmatic aspect as well; namely, how today's marketable image can use and "exploit" it for the growing rural tourism and heritage business.

One can still spot women from the Transylvanian community of Szék (Sic) - mostly over 60 , wearing their black and red traditional garments - seeking work as housekeepers in Budapest. They are the last generation of (Transylvanian) women wearing traditional peasant dress not just on the streets of the Hungarian capital but, we might say, in East Central Europe in general. What will remain after they are gone? (Figure 46) Will, or better yet, can any of the traditional clothing, which used to have rich meaning and communicated everything about the identity, age, marital and social status of its wearer, even the occasion for which it was worn, survive? It is clear that within the next 20-25 years, peasant dress in its original function and symbolism will have completely disappeared, even in those Transylvanian regions which have endured the longest.

Will the new generation manage to find festive occasions to wear traditional forms of dress in regions where the demise of folk art only transpired relatively recently? Will they realize the community- and identity-shaping potential of local costume, beyond mercantile interest, wherein folk art has already become one of the main attractions of village tourism? When original costumes become worn and faded, will there be any reliable knowledge of the traditional system of attire, will it represent any kind of emotional value to them once there is no one left to show them how a sleeve should be properly starched or a headscarf properly tied? Will folk dance performances, festivals, fairs, museum exhibitions, "tourist displays", "heritage industry" and "online presence" comprise the only afterlife of the once rich clothing tradition? The answers to these questions would make a great topic for another article. ${ }^{11}$

${ }^{111}$ An analysis on current phenomena of afterlife of folk art in Kalotaszeg region, see BALOGH FÜLEMILE 2020. 


\section{REFERENCES CITED}

ANDORKA, Rudolf

1979 A magyar községek társadalmának átalakulása [The Transformation of Hungaria Rural Society]. Budapest: Magvető.

1982 A társadalmi mobilitás változásai Magyarországon [Changes in Social Mobility in Hungary]. Budapest: Gondolat.

ANDRÁSFALVY, Bertalan

1978 Contrasting Value Orientation of Peasant Communities and its Persistence into Modernation. In Hooloman, Regina E. - Arutiunov, Serghei A. (eds.) Perspectives on Ethnicity, 233-242. The Hague, Paris: Mouton Publishers.

1979 A Dél-Dunántúl népviseletének néhány kérdése [Questions about the Folk Costume of Southern Transdanubia]. A Szekszárdi Béri Balogh Ádám Múzeum Évkönyve, VIII-IX. 211-219.

BALI, János

2010 “Otthonka, nemcsak otthonra!”: A köznépi női viselet és a divat kapcsolatának példája az 1960-as évek végétöl napjainkig [“A Housecoat Not Just for the House!": An Example of the Relationship between Popular Women's Wear and Fashion from the Late 1960s to the Present Day]. In BALI, János - Báti, Anikó - Kiss, Réka (eds.) Inde aurum - inde vinum - inde -salutem. PaládiKovács Attila 70. születésnapjára, 438-447. Budapest: ELTE BTK Faculty of Ethnography - MTA Ethnographical Institute.

BALOGH, Balázs

2009 Egy férfigeneráció sorsa Tápon a téeszesítéstöl napjainkig [The Fate of a Male Generation in Táp from Collectivization to the Present Day]. In BERTA, Péter - HoppáL, Mihály (eds.) Ethnolore. Az MTA Néprajzi Kutatóintézetének Évkönyve XXVI. 289-325. Budapest: MTA Néprajzi Kutatóintézet.

2010 Azamerikai magyarok óhaza képe [Images of the Old Country among Hungarian Americans]. In BALI, János - BÁTI, Anikó - Kiss, Réka (eds.) Inde aurum inde vinum - inde -salutem. Paládi-Kovács Attila 70. születésnapjára, 429437. Budapest: ELTE BTK Faculty of Ethnography - MTA Ethnographical Institute.

BAlogh, Balázs - Fülemile, Ágnes

2004 Társadalom, tájszerkezet, identitás Kalotaszegen. Fejezetek a regionális csoportképzés történeti folyamatairól [Society, Landscape Structure, Identity in Kalotaszeg. The Historical Processes of Regional Group Formation]. Budapest: Akadémiai Kiadó. (Néprajzi Tanulmányok).

2006 Turning Inward or Forging New Ties - Social Strategies in Diaspora Communities on the Periphery of the Historical Hungarian Region of Kalotaszeg (Zona Calatei) in Transylvania. In BALOGH, Balázs - ILYÉs, Zoltán (eds.) Perspectives of Diaspora Existence: Hungarian Diasporas in the Carpathian Basin - Historical and Current Contexts of a Specific Diaspora Interpretation and Its Aspects of Ethnic Minority Protection, 187-226. Budapest: Akadémiai Kiadó.

2008 Cultural Alternatives, Youth and Grassroots Resistance in Socialist Hungary The Folk Dance and Music Revival. Hungarian Studies 22(1-2):43-62. 
2012 Mapping Regional Structures as Outlined and Produced by a System of Marriage Ties. Acta Ethnographica Hungarica 57(1):91-126.

2020 Reprezentáció és reprezentativitás. Lépésváltás és léptékváltás a (kalotaszegi) hagyományőrzés módozataiban [Representation and Representativity. Step Change and Scale Change in (Kalotaszeg) Heritage Preservation Methods]. In JAKAB, Albert Zsolt - VAJDA, András (eds.) Ruralitás és gazdasági stratégiák a 21. században, 19-61. Kolozsvár: Kriza János Néprajzi Társaság.

BALOGH, Sándor - PöLÖsKEI, Ferenc (szerk.)

1975 Agrárpolitika és agrárátalakulás Magyarországon a felszabadulás után [Agricultural Policy and Agricultural Transformation in Hungary after Liberation]. Budapest: ELTE.

BARTHES, Roland

1982 Adivat rendszere [The Fashion System]. In KLANICZAY, Gábor-S.NAGY, Katalin (eds.) Divatszociológia I-II, I. 106-121. Budapest: Tömegkommunikációs Kutatóközpont.

Bogatyrev, Peter

1971 The Functions of Folk Costume in Moravian Slovakia. The Hague - Paris: Mouton.

Csite, András

1997 Polgárosodás-elméletek és polgárosodás-viták [Theories and Debates on Embourgeoisement]. Szociológiai Szemle 1997(3):117-137.

DiósZEGi, László

2008 Historic Moments of Hungarian Folk Dance: From the Gyöngyösbokréta to the Dance House Movement. Hungarian Studies 22(1-2):3-8.

DonÁTH, Ferenc

1977 Reform és forradalom. A magyar mezögazdaság strukturális átalakulása 19451975 [Reform and Revolution. The Structural Transformation of Hungarian Agriculture 1945-1975]. Budapest: Akadémiai Kiadó.

Fesős, Zoltán

1987 „Magyar ruha”, „szüreti bál” és az amerikai magyar etnikus kultúra néhány kérdése ["Hungarian Dress," "Harvest Ball," and Issues of HungarianAmerican Ethnic Culture]. Magyarságkutatás. A Magyarságkutató Csoport évkönyve, 267-283.

FÉL, Edit

1937 A turai viselet [The Folk Costume of Tura]. Néprajzi Értesitö XXIX:84-105.

1942 A női ruházkodás Martoson [Women's Clothing in Martos]. Néprajzi Értesitö XXXI:93-140.

1952 Újabb szempontok a viselet kutatásához. A test technikája. [New Aspects in Costume Research. Body Technique]. Ethnographia LXIII:408-415.

1962 Népviselet [Folk Costume]. Budapest: Képzőmúvészeti Alap Kiadóvállalata.

1981 „Népviselet” címszó [Folk Costume]. Magyar Néprajzi Lexikon IV, 16-27.

FÉL, Edit - HoFER, Tamás

1969a A kalotaszentkirályi kelengye, I [Dowry in Kalotaszentkirály]. Néprajzi Értesitö LI:15-36. 
1969b Proper Peasants. Traditional Life in a Hungarian Village. Viking Fund Publications in Anthropology 46., Wenner Gren Foundation for Anthropological Research Inc. Chicago: Aldine; Budapest: Corvina.

1970 A Textilgyüjtemény gyarapodása [The Expansion of the Textile Collection]. Néprajzi Értesitö LII:129-147.

1972 Bäuerliche Denkweise in Wirtschaft und Haushalt: Eine ethnographische Untersuchung über das ungarische Dorf Átány [The Peasant Mindset in Economy and Household: An Ethnographic Study of the Hungarian Village of Átány]. Göttingen: Schwartz.

1974 Geräte der Átányer Bauern [Peasant Tools in Átány]. Kopenhagen: Gyldendal; Budapest: Akadémiai Kiadó.

1983 Le vinaigre et le fiel : la vie d'une paysanne hongroise par Margit Gari [Vinegar and Gall: The Life of a Hungarian Peasant Woman by Margit Gari]. Paris : Plon; Budapest: Corvina.

FLÓRIÁN, Mária

1997 Öltözködés [Clothing]. In PALÁDI-KovÁcs, Attila et al. (eds.) Magyar néprajz $I V$. Életmód, 587-767. Budapest: MTA Néprajzi Kutatóintézet, Akadémiai Kiadó.

2001 Magyar parasztviseletek [Hungarian Peasant Costume]. Jelenlévő múlt, Budapest: Planétás Kiadó.

FÜGEDI, Márta

1997 Mitosz és valóság: A matyó népmüvészet [Myth and Reality: Matyó Folk Art]. Officina Musei 6. Miskolc: Herman Ottó Múzeum.

2001a The Discovery of Matyó Folk Art. Hungarian Heritage 2001. 9-18.

2001b Reprezentáns népcsoportok a 19-20. század fordulójának népmüvészetében [Representative Ethnic Groups in the Folk Art of the Turn of the $20^{\text {th }}$ Century]. Miskolc: Herman Ottó Múzeum.

FüLEMILE, Ágnes

1991a Batyuzó matyó asszonyok. Adatok a mezőkövesdi folklorizmus történetéhez [Matyó Peddlers. The History of Folklorism in Mezőkövesd]. In HaLÁsz, Péter (ed.) A Duna menti népek hagyományos müveltsége: Tanulmányok Andrásfalvy Bertalan tiszteletére, 375-382. Budapest: Magyar Néprajzi Társaság.

1991b Megfigyelések a paraszti női viselet változásához Magyarországon, az I. világháborútól napjainkig [Observations on the Changes in Peasant Women's Wear in Hungary, from World War I to the Present Day]. Ethnographia CII:50 78.

2000 Megfigyelések a paraszti női viselet változásához [Observations on the Changes in Peasant Women's Wear]. In FoKAsz, Nikosz - ÖRKÉNY, Antal (eds.) Magyarország társadalomtörténete III. (1945-1989), 361-368. Budapest: Új Mandátum Könyvkiadó.

2010 Hungary: Ethnic Dress. In Eicher, Joanne B. - BARTLETt, Djurdja (eds.) Berg Encyclopedia of World Dress and Fashion Vol. 9. East Europe, Russia, and the Caucasus, 169-176. Oxford (England): Berg Publishers/Oxford International Publishers.

2011 Hagyományőrzés az öltözködésben - énképek, nosztalgiák, öltözeti gesztusjelek [Preserving Traditions in Clothing - Self-Image, Nostalgia, 
Clothing Gestures]. In Diószegi, László - JuHÁsz, Katalin (eds.) Hagyomány, örökség, közkultúra: a magyar népmüvészet helye és jövője a Kárpátmedencében, 183-197. Budapest: Teleki László Alapítvány.

Fülemile, Ágnes - Stefány, Judit

1989 A kazári női viselet változása a XIX-XX. században [Changes in Kazár Women's Wear in the 19-20 ${ }^{\text {th }}$ Century]. (Dissertationes Ethnographicae 7.) Budapest: ELTE Bölcsészettudományi Kar.

FÜSTÖS, LÁSZló - GALASI, PÉTER - MANCHIN, RÓBERT

1982 Kísérlet a falusi társadalom szerkezetének sokváltozós empirikus történeti elemzésére [An Attempt at a Multivariate Empirical Historical Analysis of the Structure of Rural Society]. In VÁGVÖLGYI, András (ed.) A falu a mai magyar társadalomban, 307-336. Budapest: Akadémiai Kiadó.

G. VÁmos, Mária

1977 Népviselet Pincehelyen. Mintagyüjtemény a Tolna megyei népi hímzésekböl.

I. Kaposmente. 1-24 [Folk Costume in Pincehely. A Reference Collection of Folk Embroidery from Tolna County. I. Kaposmente, 1-24]. (Bevezetö tanulmány: G. Vámos Mária; a mintákat gyüjtötte: Horváth Anna.) Szekszárd: A szekszárdi Babits Mihály Müvelődési Központ, Rotaprint.

1979 Szakály női viseletének alakadása az 1880-as évektől a II. Világháborúig [The Shaping of Women's Wear in Szakály from the 1880s to World War II]. A Szekszárdi Béri Balogh Ádám Múzeum Évkönyve VIII-IX, 237-246. Szekszárd.

GÁBORJÁn, Alice

1969 Magyar népviseletek [Hungarian Folk Costumes]. Budapest: Corvina.

1976 Magyar népviseletek [Hungarian Folk Costumes]. Néprajzi Értesítö LVIII:1-140.

Gergely, Katalin

1978 Változások Varsány népviseletében [Changes in the Folk Costume of Varsány]. In BoDRoGi, Tibor (ed.) Varsány. Tanulmányok egy észak-magyarországi falu társadalomnéprajzához, 201-276. Budapest: Akadémiai Kiadó. (Néprajzi Tanulmányok).

1981 Paraszti öltözködés és a divat. $=$ A folklorizmus fogalma és jelenségei [Peasant Clothing and Fashion. The Concept and Phenomena of Folklorism]. In ZELNIK, József (ed.) Folklór, társadalom, müvészet 10-11, 219-233. Kecskemét.

1984 Öltözködés, viselet [Clothing, Costume]. In BÁRTH, János (ed.) Kecel története és néprajza, 793-818. Kecel: Kecel Nagyközség Tanácsa.

GYIMESI, Sándor

1968 A kapitalizmus és a paraszti gazdaság [Capitalism and the Peasant Economy]. Ethnographia LXXIX:149-162.

GyÖRFFY, István

1956 Matyó népviselet [Matyó Folk Costume]. Budapest: Képzőmüvészeti Alap Kiadóvállalata.

HaLÁsz, Péter

1975 A termelöszövetkezeti mozgalom története Apátfalván [History of the cooperative movement in Apátfalva]. Budapest: Akadémiai Kiadó. (Agrártörténeti tanulmányok 3.) 
HANN, C. M.

1980 Tázlár, a village in Hungary. Cambridge: Cambridge University Press.

HARCSA, István

2003 Paraszttalanítás - egy fogalom születése [De-Peasantization - the Birth of a Concept]. Századvég 2003(3):77-85.

Hofer, Tamás

1975 Három szakasz a magyar népi kultúra XIX-XX. századi történetében [Three Stages in the History of Hungarian Folk Culture in the $19^{\text {th }}-20^{\text {th }}$ Century]. Ethnographia LXXXVI:398-414.

1980a Changes in the style of folk art and various branches of folklore in Hungary during the $19^{\text {th }}$ century - An Interpretation. Acta Ethnographica Hungarica XXIX:149-165.

1980b The Creation of Ethnic Symbols from the Elements of Peasant Culture. In Sugar, Peter. F. (ed.) Ethnic Diversity and Conflict in Eastern Europe, 101145, 463-472. Santa Barbara, Cal. - Oxford.

1984 Peasant Culture and Urban Culture in the Period of Modernization: Delineation of a Problem Area Based on Data from Hungary. In WINNER, Irene P. - Winner, Thomas, G. (eds.) The Peasant and the City in Eastern Europe. Interpenetrating Structures, 111-129. Cambridge, MA.

1991 Construction of the 'Folk Cultural Heritage' in Hungary and Rival Versions of National Identity. Etnologia Europaea 21(2):145-170.

HoFer, Tamás - FÉL, Edit

1975 Magyar népmüvészet [Hungarian folk art]. Budapest: Corvina.

1979 Hungarian Folk Art. Oxford: Oxford University Press.

HoFFMANN, Tamás

1972 A parasztság csődje és kultúrája (Magyarország - XIX. század) [The Fall and Culture of the Peasantry (Hungary $-19^{\text {th }}$ Century) $]$. Néprajzi Értesitö LIV:105-115.

Hollos, Marida - Maday, Bela C. (eds.)

1983 New Hungarian Peasants: an East-Central European Experience with Collectivization. Social Science Monographs, New York: Brooklyn College Press.

Huseby-Darvas, Éva V.

2000 Hungarian Village Women in the Marketplace during the Late Socialist Period. In Seligmann, Linda (ed.) Women Traders in Cross-Cultural Perspectives: Mediating Identities, Marketing Wares. Palo Alto, CA: Stanford University Press.

ILyÉs, Sándor - Peti, Lehel - Pozsony, Ferenc (eds.)

2008 Local and Transnational Csángó Lifeworlds. Kolozsvár: Kriza János Néprajzi Társaság.

JÁvOR, Katalin

1978 Kontinuitás és változás a társadalmi és tudati viszonyokban [Continuity and Change in Social Relations and Consciousness]. In Bodrogi, Tibor (ed.) Varsány. Tanulmányok egy észak-magyarországi falu társadalomnéprajzához, 295-375. Budapest: Akadémiai Kiadó. (Néprajzi Tanulmányok). 
JuHÁsz, Pál

1964 A falusi betegek neurosisának kórokai [The Causes of Neurosis in Rural Patients]. Ideggyógyászati Szemle 1964(2):37-44.

1965 A mezőgazdasági termelőszövetkezeti mozgalom a falusiak neurózisának szempontjából [The Agricultural Cooperative Movement in Terms of the Neurosis of Rural Populations]. In Dr. Gegesi Kiss, Pál (ed.) Pszichológiai tanulmányok. VII, 245-254. Budapest: Akadémiai Kiadó.

1970 Egy kelet-magyarországi falu lakói neurózisának szociogén kórokai [Sociogenic Causes of the Neurosis of the Inhabitants of a Village in Eastern Hungary]. Magyar Tudomány 1970(2):90-103.

KAPROS, Márta

1991 „Jönni, menni” viselet a Nógrád megyei Patak községben 1985-ben [The "Come-And-Go" Costume in the Village of Patak in Nógrád County in 1985]. I. Nógrád Megyei Múzeumok Évkönyve XVII:207-245.

1994 „Jönni, menni” viselet a Nógrád megyei Patak községben 1985-ben. II. Nógrád Megyei Múzeumok Évkönyve XIX:113-127.

1995 „Jönni, menni” viselet a Nógrád megyei Patak községben 1985-ben. III. Nógrád Megyei Múzeumok Évkönyve XX:117-129.

2004 A matyó kézimunkák a nógrádi falvak textilkultúrájában [Matyó handicrafts in the textile culture of the villages of Nógrád]. A Nógrád Megyei Múzeumok Évkönyve XXVII-XXVIII (2003-2004):225-238.

Kovícs, Csaba

2013 Panaszok a kollektivizálás befejező hullámának időszakából: az egyéni és a szövetkezeti gazdálkodás problémáinak sajátosságai [Complaints from the Final Wave of Collectivization: The Peculiarities of the Problems of Individual and Cooperative Farming]. Múltunk 2013(3):207-251.

Kovács, Imre

2003 A magyar társadalom „paraszttalanítása” - európai összehasonlításban [The "de-peasantization" of Hungarian Society - a European Comparison]. Századvég 2003(2):41- 65.

LAKI, László

2003 Törés és folyamatosság [Fracture and Continuity]. Századvég 2003(3):87-92.

LAMPLAND, Martha

1995 The Object of Labor: Commodification in Socialist Hungary. Chicago and London: University of Chicago.

2016 The Value of Labor: The Science of Commodification in Hungary, 1920-1956. Chicago-London: The University of Chicago Press.

LosoncZi, Ágnes

1977 Az életmód az időben, a tárgyakban és az értékekben [Way of Life in Time, Objects, and Values]. Budapest: Gondolat.

MáRKUS, István

1991a A hazai mezőgazdasági kisárutermelés az 1960-70-es években [Domestic Agricultural Small-Scale Production in the 1960s and 70s]. Századvég 2-3:193-201.

1991b Az ismeretlen föszereplö. Tanulmányok [The Unknown Protagonist. Studies]. Szépirodalmi Könyvkiadó, Budapest. 
Mauss, Marcel

1973 Techniques of the body. Economy and Society 2(1):70-88.

Mendras, Henri

1970 The Vanishing Peasant: Innovation and Change in French Agriculture. Cambridge, Mass.: MIT Press. (M.I.T. Studies in Comparative Politics.)

Molnár, József

1996 „A” háztáji [The backyard economy]. In Orosz, István - Für, Lajos-RoMáNY, Pál (eds.) Magyarország agrártörténete, 631-643. Budapest: Mezőgazda Kiadó.

ÓDOR, János

1979 Sióagárd női viseletének rövid története [The Brief History of Sióagárd Women's Costume]. A Szekszárdi Béri Balogh Ádám Múzeum Évkönyve VIIIIX, 253-258. (Szekszárd).

Ö. KovÁcs, József

2008 A kollektivizálás kortársi tapasztalata [The Contemporary Experience of Collectivization]. In HonvárI, János (ed.) „,20. századi magyar gazdaság és társadalom”. Konferenciakötet, 118-131. Györ.

2009 „Sürített népnevelő”. A kollektivizálás tapasztalattörténete (1958-1959) [„Concise Popular Educator”: The Experience History of Collectivization (1958-1959)]. Korall 36. 2009. július. 31-54.

2012 A paraszti társadalom felszámolása a kommunista diktatúrában. A vidéki Magyarország politikai társadalomtörténete 1945-1965 [The Abolition of Peasant Society in the Communist Dictatorship. The Political and Social History of Rural Hungary 1945-1965]. Korall 2012:367-382.

PÁLFi, Csaba

1970 A Gyöngyösbokréta története [History of the Gyöngyösbokréta]. Tánctudományi tanulmányok 1969-70, 115-161.

PetÁnovics, Katalin

1971 A sármelléki női viselet a századfordulótól napjainkig [Women Costume in Sármellék from the Turn of the Century to the Present]. A Veszprém Megyei Múzeumok Közleményei 10. 315-338.

PÉTERBENCZE, Anikó

1990 Kecele, kacó, zsámboki matyó. A női viselet változása Zsámbokon 1900-1990 [Kecele, kacó, zsámboki Matyó. Changes in women's costume in Zsámbok 1900-1990]. Életmód és tradíció. Budapest: MTA Néprajzi Kutató Csoport.

POZSONY, FERENC

2006 The Hungarian Csángó of Moldova. Buffalo-Toronto: Corvinus Publishing.

SÁRKÁNY, Mihály

1983 Economic Change in a Northern Hungarian Village. In Hollos, Marida Maday, Bela C. (eds.) New Hungarian Peasants: An East-Central European Experience with Collectivization, 25-55. Social Science Monographs, New York: Brooklyn College Press.

2019 Amerikai és brit kulturális antropológusok és szociálantropológusok Magyarországon a szocializmus időszakában [American and British Cultural And Social Anthropologists in Hungary During Socialism]. In BALI, János BÁRTH, Dániel - DEÁKy, Zita - VÁmos, Gabriella (eds.) Kövek, fák, források: 
Tanulmányok Mohay Tamás hatvanadik születésnapjára, 428-441. Budapest: Simon, Péter ELTE BTK Néprajzi Intézet.

1984 A magyar parasztság sorsfordulója 1946-1949 [A Twist of Fate for the Hungarian Peasantry 1946-1949]. Budapest: Kossuth Könyvkiadó.

ŠmidChEns, Guntis

1999 Folklorism Revisited. Journal of Folklore Research 36(1):51-70.

STEFÁNY, Judit

1986 Paraszti öltözködés [Peasant Clothing]. História 8(5-6):32-33.

SzARVAS, Zsuzsa

1990 A mezőkövesdi zsidóság szerepe a magyar népmüvészet elterjesztésében [The Role of the Jewry of Mezökövesd in the Spread of Hungarian Folk Art]. In KRIZA, Ildikó (ed.) A hagyomány kötelékében. Tanulmányok a magyarországi zsidó folklór köréböl, 217-222. Budapest: Akadémiai Kiadó.

SzELÉNYI, Iván (with Robert Manchin, Pál Juhász, Bálint Magyar and Bill Martin)

1988 Socialist Entrepreneurs: Embourgeoisement in Rural Hungary. Madison: University of Wisconsin.

TÁnczos, Vilmos

2003 Hungarians in Moldavia. Hungarian Heritage 2002(3):11-28. (Budapest: European Folklore Institute).

TöZsÉr KapCsos, Anna

2004 Palócul tanított imádkozni anyám. Egy kazári palóc asszony önéletírása. [My mother taught me to pray in the Palóc language - The life of a Palóc woman in Kazár] (Szerkesztette és sajtó alá rendezte: Balogh, Balázs; Fazekas, Zsuzsa; Fülemile, Ágnes; Stefány, Judit) Budapest: L'Harmattan, Európai Folklór Intézet.

TöTSZEGI, Tekla

2009 A mérai viselet változása a 20. században. A mérai magyar nöi viselet és kontextusai [Changes in the Costume of Mera in the $20^{\text {th }}$ Century. Hungarian Women's Costume in Mera and Its Contexts]. Marosvásárhely: Mentor.

U. KERÉKGYÁRTó, Adrienne

1980 Áttérés a paraszti viseletről a városi viseletre [Transition from Peasant Wear to Urban Wear]. In BaLAssa, Iván (ed.) Alsónémedi története és néprajza, 369403. Alsónémedi: Községi Tanács.

ÚJvÁRY, Ferenc

1981 Bokréták a Galga-völgyében [Pearly Bouquets in the Galga Valley]. Gödöllö: Petőfi Sándor Müvelődési Központ.

VÁGVÖLGYI, András (ed.)

1982 A falu a mai magyar társadalomban [The Village in Today's Hungarian Society]. Budapest: Akadémiai Kiadó.

VALuCH, Tibor

2000 A Cultural and Social History of Hungary 1948-1990. In KósA, László (ed.) A Cultural History of Hungary in the Nineteenth and Twentieth Centuries. Budapest: Corvina, Osiris.

2001 Magyarország társadalomtörténete a XX. század második felében [The social history of Hungary in the second half of the $20^{\text {th }}$ century]. Budapest: Osiris. 
2003a A történeti parasztság változásai az 1960-as években [Changes in historical peasantry in the 1960s]. Századvég 2003(1):3-29.

2003b „Községünkben nagy előrehaladást értünk el a szocializmus építése terén.” A történeti parasztság és az életmód változásai Magyarországon a hatvanas években ["In our village, we have made great progress in building socialism." Changes in historical peasantry and way of life in Hungary in the sixties]. In RAINer M., János (ed.) Múlt századi hétköznapok. Tanulmányok a Kádárrendszer kialakulásának időszakáról, 129-176. Budapest: 1956-os Intézet.

VARGA, Zsuzsanna

2001 Politika, paraszti érdekérvényesítés és szövetkezetek Magyarországon 19561967 [Politics, Peasant Advocacy, and Cooperatives in Hungary 1956-1967], Budapest: Napvilág Kiadó.

2009 „Földindulás után.” A hatalom és a parasztság Magyarországon az 1960-as évek első felében ["After the upheaval." Power and Peasantry in Hungary in the First Half of the 1960s]. Történelmi Szemle 2009(2):231-258.

2012 Mit ér a munkás, ha paraszt (is)? A falusi munkásság és a hatalom a Kádárkorszakban [What is a Worker if He is (Also) a Peasant? Rural Workers and Power in the Kádár Era]. Korall 49:37-57.

ZólYomi, József

1979 A Mailáth-uradalom cselédeinek viselete a két világháború között [Clothing of the servants of the Mailath estate between the two world wars]. Nógrád Megyei Múzeumok Évkönyve V., 199-226.

Ágnes Fülemile is a Senior Research Fellow at the Institute of Ethnology of the RCH, "An Institute of Excellence of the Hungarian Academy of Sciences", Budapest, and Editor-in-chief of the journal Acta Ethnographica Hungarica. Qualifications: PhD in European Ethnology, MA in Art history, History and Ethnography (ELTE, Budapest), MPhil in History of Dress (University of London). Further work experience: lecturer at the Education Abroad Program of the University of California in Budapest (1991-2006) and CIEE Exchange Program at Corvinus University, Budapest (1992-2018); director of the Balassi Institute Hungarian Cultural Center in New York (2011 - 2014) and curator of the "Hungarian Heritage: Roots to Revival" Hungarian Program of the 2013 Smithsonian Folklife Festival in Washington, D.C.; Visiting Hungarian Chair Professor at Indiana University, Bloomington (2006-2009); visiting lecturer at Rutgers University (1999); Fulbright scholar at the Costume Institute, Metropolitan Museum, NY (1993), and Anthropology Department, UC Berkeley (1992). E-mail: fulemile.agnes@btk.mta.hu

Open Access. This is an open-access article distributed under the terms of the Creative Commons Attribution-NonCommercial 4.0 International License (https://creativecommons.org/licenses/by-nc/4.0/), which permits unrestricted use, distribution, and reproduction in any medium for non-commercial purposes, provided the original author and source are credited, a link to the CC License is provided, and changes - if any - are indicated. 